\title{
FLORA DA SERRA DO CIPÓ, MINAS GERAIS: ERICACEAE
}

\author{
GERSON OLIVEIRA ROMÃO\&VINICIUS CASTRO SOUZA
}

\author{
Departamento de Ciências Biológicas, Escola Superior de Agricultura Luiz de Queiroz, \\ Universidade de São Paulo, Avenida Pádua Dias 11, caixa postal 9, \\ 13418-900 - Piracicaba, SP, Brasil.goromao@usp.br,vcsouza@usp.br
}

\begin{abstract}
Flora of the Serra do Cipó, Minas Gerais: Ericaceae): The study of the family Ericaceae is part of the project of "Flora of the Serra do Cipó, Minas Gerais, Brazil". In that area, the family is represented by two genera, with their respective number of species: Agarista (8) and Gaylussacia (17), of which A. duartei,A. virgata, G. centunculifolia and G. vitis-idaea are endemics. Keys to genera and species, descriptions, illustrations and comments on their geographical distribution, habitat, phenology and morphological variability are presented.
\end{abstract}

Key words: campo rupestre, Espinhaço Range, Ericaceae.

Resumo - (Flora da Serra do Cipó, Minas Gerais: Ericaceae): O estudo da família Ericaceae é parte do levantamento da Flora da Serra do Cipó, Minas Gerais, Brasil. A família está representada na área por dois gêneros, com seus respectivos número de espécies: Agarista (8) e Gaylussacia (17), das quais A. duartei,A. virgata, G. centunculifolia e G. vitis-idaea são endêmicas. São apresentadas chaves para gêneros e espécies, descrições, ilustrações e comentários sobre habitat, distribuição geográfica, fenologia e variabilidade morfológica.

Palavras-chave: campo rupestre, Cadeia do Espinhaço, Ericaceae.

\section{ERICACEAE Juss.}

Subarbustos, arbustos, árvores, lianas, epífitas ou ervas aclorofiladas e micotróficas. Tricomas unicelulares ou multicelulares, simples, dendríticos, glandulares ou lepidotos; geralmente com glândulas diminutas. Folhas simples, alternas a opostas ou verticiladas, geralmente coriáceas, raramente carnosas, decíduas ou não; gemas peroladas; estípulas ausentes. Inflorescência em corimbo, fascículo, panícula, racemo ou flores solitárias; pedúnculo comumente bracteado na base; brácteas florais e bractéolas raramente ausentes, decíduas ou não. Flores vistosas, bissexuadas, raramente unissexuadas (em plantas dióicas), actinomorfas ou ligeiramente zigomorfas; cálice (3-)5(-7)-lobado; pétalas (3-)4-5(-7), conatas ou raramente livres, corola urceolada, cilíndrica, campanulada ou infundibuliforme; androceu diplostêmone, raramente isostêmone, estames apendiculados ou não, filetes livres ou epipétalos, anteras dorsifixas ou basifixas, com 2 poros ou fendas apicais; disco nectarífero intraestaminal comumente presente; gineceu gamocarpelar, ovário súpero ou ínfero, 2-5(-10)locular, óvulos 1 ou muitos por lóculo. Fruto bacáceo, drupóide (nuculânio) ou capsular. Sementes de tamanho reduzido, aladas ou não. A família abrange 124 gêneros e aproximadamente 4100 espécies (Judd et al., 2008), de distribuição cosmopolita, ocorrendo principalmente nos terrenos ácidos das regiões temperadas e subtropicais de ambos os hemisférios, comumente em montanhas nos trópicos (Kinoshita-Gouvêa 1980 inéd.; Luteyn et al. 1995). Segundo Luteyn (2002), a maioria das Ericaceae neotropicais apresenta síndrome de ornitofilia, como flores e brácteas não aromáticas com coloração chamativa, corola tubular e presença de disco nectarífero.

No Brasil, a família está representada por 11 gêneros e 96 espécies, das quais 71 são endêmicas, distribuídas principalmente nas áreas de maiores altitudes nos domínios Cerrado e Floresta Atlântica, ocasionalmente Caatinga e Amazônia (Kinoshita \& Romão 2010, 2013).

Bibliografia básica: Judd (1984, 1995), KinoshitaGouvêa (1980 inéd.), Kinoshita (1995, 1996), Kinoshita \& Romão $(2011,2012)$, Luteyn et al. (1995), Marques (1975), Meisner (1863), Romão \& Souza (2003), Romão et al. (2004), Silva \& Cervi (2006), Sleumer $(1959,1967)$.

\section{Chave para os gêneros}

1. Filete geniculado, antera com tecas truncadas; ovário súpero, 5-locular, lóculos multiovulados; fruto cápsula

1'. Filete reto, antera com tecas longo-tubulosas; ovário ínfero, pseudo-10-locular, lóculos 


\section{Agarista D. Don ex G. Don}

Subarbustos a árvores, geralmente eretos, às vezes esguios. Folhas alternas ou subopostas, em geral imbricadas, subcoriáceas a rigidamente coriáceas, raramente cartáceas, persistentes, abertas ou conduplicadas, concolores; pecíolo robusto ou delgado, às vezes flexível; limbo com margem inteira ou serreada a crenada, geralmente revoluta, frequentemente com glândulas apicais, glabro a tomentoso, às vezes híspido, tricomas simples ou glandulares, com ou sem glândulas foveoladas enegrecidas associadas às nervuras secundárias. Inflorescência em panícula ou racemo, bracteada ou não na base do eixo; bráctea 1 , pouco vistosa, inserida na base do pedicelo; bractéolas 2, inseridas da base até o ápice do pedicelo. Flores 5-meras, bissexuadas, diplostêmones; cálice conato na base, não carnoso; corola gamopétala, urceolada a cilíndrica, alva ou vermelha; estames 10 , iguais entre $\mathrm{si}$, eretos, filetes geniculados, achatados, anteras bífidas, dorsifixas na metade inferior, deiscência poricida, teca truncada, desprovida de apêndice; ovário súpero, anelado na base, 5-locular, lóculos multiovulados. Cápsula loculicida, globosa a ovóide, septos lenhosos, costada; sementes fusiformes.

O gênero é constituído por 31 espécies, ocorrendo predominantemente nas Américas, com apenas uma espécie na África, Agarista salicifolia (Lam.) G. Don. No Brasil, estão relacionadas 21 espécies ocorrendo principalmente nos campos rupestres da Cadeia do Espinhaço até os campos de altitude nas regiões Sul e Sudeste (Judd 1995, Kinoshita \& Romão 2013), das quais oito espécies são encontradas na Serra do Cipó.

Sleumer (1959) reconheceu as espécies de AgaristaD. Don ex G. Don na circunscrição do gênero LeucothoeD. Don. Entretanto, baseado em estudos cladísticos, Judd (1984) restabeleceu o gênero Agarista, que é caracterizado por apresentar porte geralemete arbustivo e sempre verde, inflorescências racemosas, corolas ureoladas a cilíndricas, filetes geniculados e frutos capsular-loculicidas.

Chave para as espécies

1. Pecíolo delgado, flexível, 6-35 mm compr.

2. Folhas $0,1-0,4(-0,6) \mathrm{cm}$ larg.; limbo linear ou raro estreitamente elíptico

2 '. Folhas $0,8-2,6 \mathrm{~cm}$ larg.; limbo ovalado, lanceolado, elíptico ou oblongo.

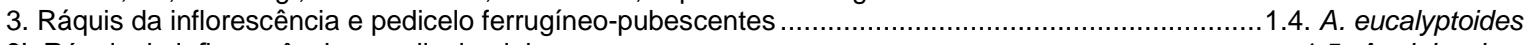

3'. Ráquis da inflorescência e pedicelo glabros ..1.5. A. glaberrima

1'. Pecíolo robusto, rígido, $1-9 \mathrm{~mm}$ compr.

4. Folhas conduplicadas, 0,1-0,3 cm larg.; limbo linear 1.3. A. duartei

4'. Folhas planas, 0,5-3,2 cm larg.; limbo ovalado, elíptico, lanceolado, oblongo ou suborbicular

5. Ramos e folhas providos de tricomas glandulares; folhas imbricadas, com margem subinteira a serrilhada

5'. Ramos e folhas desprovidos de tricomas glandulares, apenas com tricomas simples ou glabros; folhas não imbricadas, com margem inteira.

6. Folhas cartáceas; base do limbo obtusa ou arredondada, raramente aguda; cálice pubescente e frequentemente hirsuto-glandular na base....

6'. Folhas coriáceas ou rigidamente coriáceas; base do limbo cordada ou arredondada; cálice apenas pubescente.

7. Folhas esparsamente pubérulas a tomentelas na nervura central, glândulas foveoladas conspícuas e enegrecidas na face inferior, ápice com múcron ca. $1 \mathrm{~mm}$; corola vermelha ou rosada

7'. Folhas glabras ou esparsamente pubescentes na nervura central, glândulas foveoladas inconspícuas na face inferior, ápice com múcron ca. $2 \mathrm{~mm}$; corola alva

1.1. Agarista angustissima Taub., Bot. Jahrb.

Syst. 17: 513. 1893.

Sin.:Leucothoe angustissima (Taub.) Sleum., Bot. Jahrb. Syst. 78: 451. 1954.

Fig. 1. H.

Arbusto, 1-3 $\mathrm{m}$ alt., ereto, às vezes subescandente. Tricomas simples, alvos, nas folhas e flores; tricomas glandulares ausentes. Ramos glabros, esparsamente foliados. Folhas alternas ou subopostas, não imbricadas, (2,4-)4,2-8,3×0,1-0,4($0,6) \mathrm{cm}$, conduplicadas, subcoriáceas, não espessas; pecíolo 6-22 $\mathrm{mm}$ compr., delgado, flexível, glabro ou esparsamente pubescente na base; limbo linear, raro estreitamente elíptico, ápice agudo, mucronulado, com glândula apical espesso-alongada, base atenuada, margem inteira, plana, ambas as faces glabras ou esparsamente pubescentes ao longo da nervura central da face superior, glândulas foveoladas ausentes, nervação reticulódroma, nervuras ligeiramente proeminentes em ambas as faces. Panículas ou racemos terminais ou axilares subapicais, bracteados, 4-10-floro; ráquis $1,2-5,2 \mathrm{~cm}$, glabra; bráctea 2-3 $\mathrm{mm}$ compr., triangular-setiforme, ciliada; bractéolas 1-2 mm compr., linear-setiformes, inseridas na porção basal até a mediana do pedicelo. Flores laxas; pedicelo 3-7 mm compr., glabro; cálice 1-3 mm compr., pubescente apenas nos bordas dos 
Flora da Serra do Cipó, Minas Gerais: Ericaceae
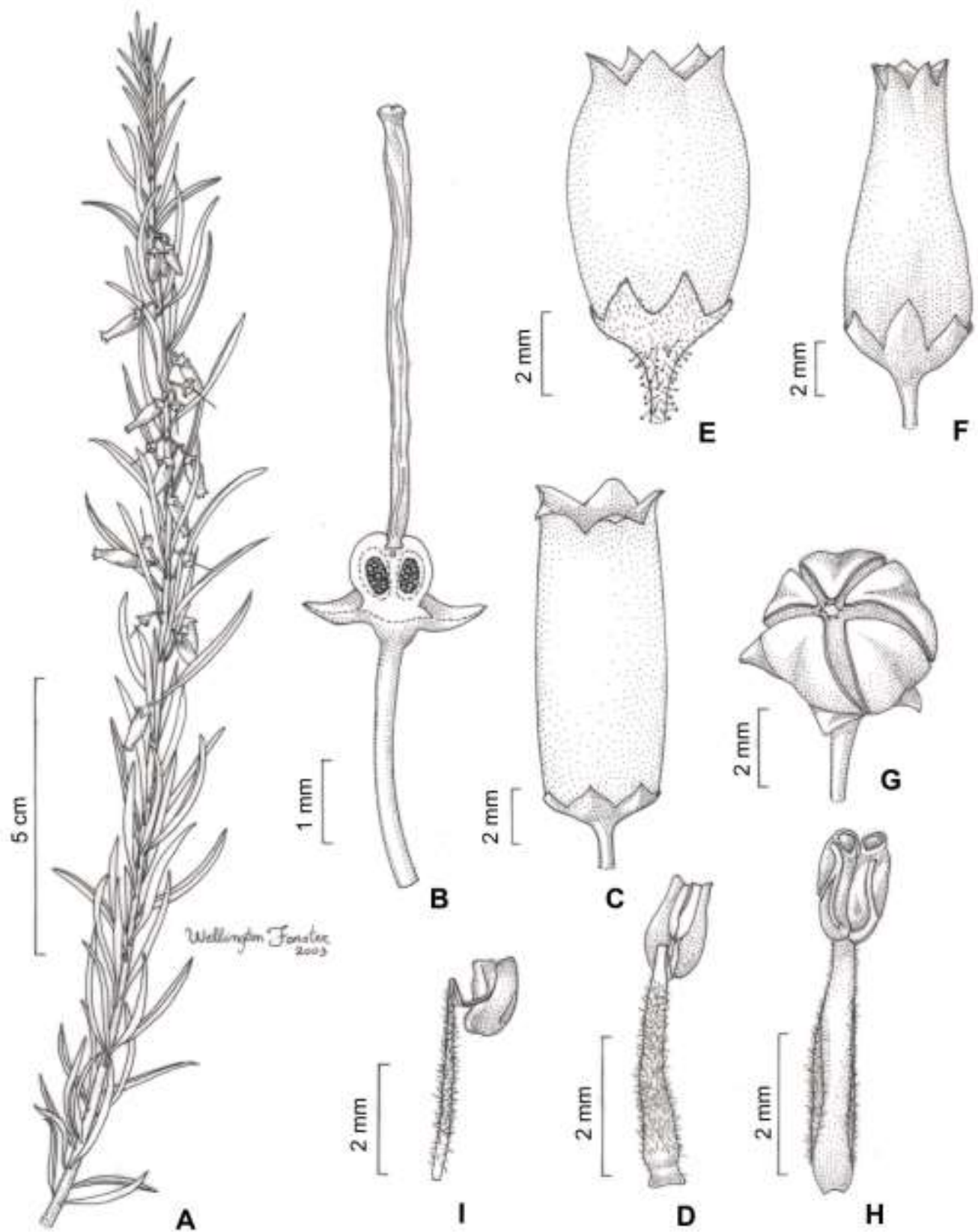

E

$\mathbf{F}$
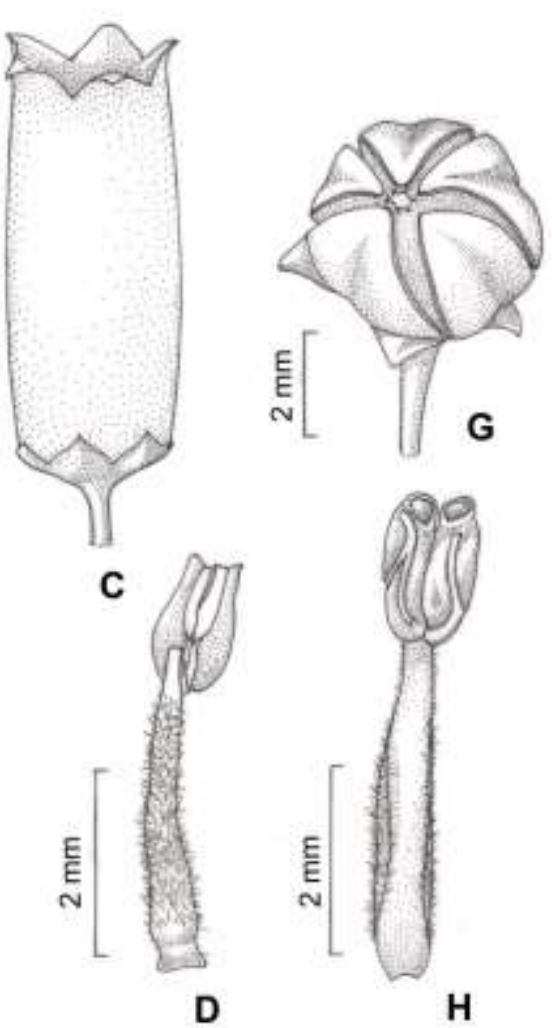

Fig. 1 - Agarista. A-C A. duartei (G.O. Romão 536): A. Ramo florido; B. Ovário súpero; C. Flor com corola cilíndrica. D-E. A. virgata (G.O. Romão et al. 746): D. Vistal dorsal do estame. E. Flor com corola tubuloso-urceolada. F. A. pulchra (Damazio s.n. RB 55030): F. Corola urceolada. G. A. oleifolia var. oleifolia (J.R. Pirani et. al. CFSC 7462): G. Cápsula H. A. angustissima (M. Meguro et. al. CFSC 9380): H. Vista frontal do estame. I. A. eucalyptoides (H.S. Irwin et. al. 20802): I. Vista lateral do estame. 
lobos; corola urceolada, tubuloso-urceolada ou cilíndrica, 6-11 mm compr., amarelada ou cremeesverdeada, botões às vezes com ápice avermelhado, glabra, lobos retos; estames 5-6 mm compr., filete densamente lanoso, antera lisa; ovário glabro, estilete ca. $7 \mathrm{~mm}$ compr., glabro. Fruto 4-7 mm diâm., subgloboso, castanho, glabro.

Material examinado: Congonhas do Norte, Serra do Cipó, Serra Talhada, $18^{\circ} 52^{\prime} S 43^{\circ} 14^{\prime}$ W, R.C. Forzza et al. 726, 3.III.1998, fl. (SPF). Santana do Pirapama, Serra do Cipó, Serra Talhada, distrito de São José da Cachoeira, Fazenda Toucan Cipó: 1900'22"S 4345'20"W, V.C. Souza et al. 32538, 17.II.2007, fr. (BHCB, ESA, HUEFS, K, MBM, PORT, RB, SP, SPF, UB, UEC); idem, G.O. Romão et al. 2350, 17.Il.2007, fr. (ESA); idem, trilha da Senhorinha, 18,9422오 43,7498W, V.C. Souza et al. 32859, 19.II.2007, fr. (BHCB, ESA, K, RB, SPF); idem, trilha da Senhorinha, 1856'31,8'S 4344'59,2'W, G.O. Romão et al. 2360, 19.Il.2007, fr. (ESA, M). Santana do Riacho, Serra do Cipó: Fazenda Paraúna, A.M.G.A. Tozzi \& L.S. Kinoshita 593, 23.XI.2000, fl. (UEC); Parque Nacional da serra do Cipó, próximo a estátua do Juquinha, L.S. Kinoshita et al. 00/186, 22.XI.2000, fl. (UEC); Rodovia Belo Horizonte-Conceição do Mato Dentro, $\mathrm{Km}$ 125, CFSC 9380, M. Meguro et al., 1.XI.1985, fl.fr. (ESA, RB, SPF); idem, Km 125, CFSC 9380, A.M. Giulietti et al., 1.XI.1985, fl. (UEC); RPPN Brumas do Espinhaço, J. Ordones et al. 1873, 18.IV.2012, fl. (UEC). Material adicional: MINAS GERAIS, Diamantina: estrada para Biri-Biri, J.R. Stehmann et al. 2514, 23.IX.1998, fl.fr. (BHCB, ESA); estrada para Conselheiro Mata, A.M. Giulietti et al. CFCR 1839, 30.VIII.1981, fr. (SPF, UEC); estrada para Mendanha, a $5 \mathrm{Km}$ de Diamantina, Splett 597, 22.VIII.1994, fl.fr. (UEC); entre Sentinela e a entrada da cidade, M.M. Nogueira et al. s.n., 25.IX.1998, fl.fr. (BHCB 48599, ESA 65767).

Agarista angustissima distribui-se na Cadeia do Espinhaço, restrita às regiões da Serra do Cipó e Planalto Diamantina, Minas Gerais. Na Serra do Cipó é encontrada em campos rupestres, sobre solos pedregosos não alagáveis ou entre blocos rochosos. Foi coletada com flores em março e maio e de agosto a novembro, com frutos de agosto a novembro e em fevereiro.

Segundo Judd $(1984,1995)$, essa espécie às vezes pode apresentar tricomas glandulares nos râmulos e margens das folhas jovens, além de glândulas foveoladas na face inferior das folhas, mas estas características não foram observadas no material examinado. Foi observado no espécime Forzza 726 a presença de folhas na base da planta ligeiramente mais largas $(0,6 \mathrm{~cm})$ e estreitamente elípticas.

No aspecto geral da planta, essa espécie assemelha-se a $A$. duartei por apresentarem folhas lineares e conduplicadas. Enquanto $A$. angustissima apresenta folhas subcoriáceas, pecíolo delgado e flexível com 6-22 $\mathrm{mm}$ de comprimento, $A$. duartei possui folhas rigidamente coriáceas, pecíolo robusto, rígido e com (1-)2-7 mm. Ilustrações em Judd (1995).
1.2. Agarista coriifolia (Thunb.) J.D. Hooker ex Nied., Bot. Jahrb. Syst. 11: 236. 1889.

Sin.: Leucothoe coriifolia (Thunb.) DC., Prodr. 7: 605. 1839.

Leucothoe crassifolia (Pohl) DC., Prodr. 7: 605. 1839.

Leucothoe pohlii (G. Don) Sleum., Bot. Jahrb. Syst. 78: 463. 1959.

Subarbusto a arbusto, 0,3-1,6 m alt., base às vezes procumbente. Tricomas simples, alvos, nos ramos, folhas, flores e frutos; tricomas glandulares ausentes. Ramos glabros ou esparsa a densamente pubérulos ou pubescentes, esparsamente foliados. Folhas alternas, não imbricadas, 1,6-7,3×1,1-3,2 cm, planas ou ligeiramente abauladas, coriáceas ou rigidamente coriáceas; pecíolo 2-9 mm compr., robusto, rígido, glabro ou pubérulo a pubescente; limbo ovalado a lanceolado, raramente elíptico, ápice arredondado a obtuso, raramente emarginado ou agudo, mucronado, múcron ca. $1 \mathrm{~mm}$, com glândula apical espesso-alongada, base cordada ou arredondada, margem inteira, plana ou ligeiramente revoluta, ambas as faces esparsamente pubérulas a tomentelas na nervura central, glândulas foveoladas conspícuas e enegrecidas associadas às nervuras secundárias na face inferior, nervação reticulódroma, nervuras ligeiramente proeminentes em ambas as faces. Panículas ou racemos terminais ou axilares subapicais, bracteados, 8-44-floro; ráquis 1,9-26,8 cm, avermelhada, glabra a densamente pubescente; bráctea 1-3 mm compr., triangular-setiforme, pubescente ou apenas ciliada; bractéolas 1-2 mm compr., linear-setiformes, inseridas na base ou na porção basal do pedicelo. Flores geralmente congestas; pedicelo 3-15 mm compr., glabro a densamente pubescente; cálice 2-3 $\mathrm{mm}$ compr., esparsamente pubescente na base ou apenas nas bordas dos lobos; corola urceolada ou tubulosourceolada, raramente cilíndrica, 6-11 mm compr., vermelha ou rosada, espessada, glabra, lobos retos ou ligeiramente recurvados; estames 3-4 mm compr., filete densamente tomentoso, antera lisa; ovário glabro ou densamente pubescente, estilete ca. $4,5 \mathrm{~mm}$ compr., glabro ou raramente pubescente na base. Fruto 5-8 mm diâm., subgloboso, avermelhado a castanho, glabro ou pubescente.

Material examinado: Jaboticatubas, Serra do Cipó, Rodovia Lagoa Santa-Conceição do Mato DentroDiamantina: Km 117, CFSC 5134, J. Semir et al., 5.IX.1974, fl. (UEC); Km 123, CFSC 4375, J. Semir et al., 3.IX.1973, fl. (SP, UEC); idem, vale do córrego Chapéu de Sol, CFSC 6519, I. Cordeiro \& J.R. Pirani, 5.IX.1980, fl.fr. (ESA, SP, SPF, UEC); Km 126, CFSC 4318, J. Semir et al., 3.IX.1973, fl.fr. (SP, UEC); estrada da Usina, ca. $10 \mathrm{Km}$ da estrada principal, CFSC 3034, A.B. Joly \& J. Semir, 21.VIII.1972, fl. (SP, UEC). Santa Luzia, Serra do Cipó: Km 127, M. Barreto 529, 24.VIII.1933, fl. (RB); Km 131, M. Barreto 530, 24.VIII.1933, 
fl. (RB). Santana do Riacho, Serra do Cipó, Rodovia Belo Horizonte-Conceição do Mato Dentro: Km 107, CFSC 8856 e 8946, E. Forero et al. 7943 e 8033, 7.IX.1980, fl. (SP, SPF); $\mathrm{Km} \mathrm{109,} \mathrm{CFSC} \mathrm{8715,} \mathrm{E.} \mathrm{Forero} \mathrm{et} \mathrm{al.} \mathrm{7806,} \mathrm{6.IX.1980,} \mathrm{fl.}$ (ESA, SP, SPF); Km 116,5, G.O. Romão 538 e 539 , 2.XI.2000, fl.fr. (ESA, SPF); idem, 19'16'15,3"S 4332'51,5"W, G.O. Romão et al. 896 e 915, 10.I.2003, fr. (ESA); idem, G.O. Romão et al. 1103, 5.XII.2004, fr. (ESA, RB, SP, UEC); Km 117, G. Martinelli 4261, 25.IV.1978, fl.fr. (RB); Km 120-121, CFSC 7302 e 7303, N.L. Menezes, 6.X.1975, fl.fr. (SPF, UEC); idem, CFSC 8819, E. Forero et al. 7906, 6.IX.1980, fl. (SP); Km 125, CFSC 12098, J.R. Pirani et al., 26.III.1991, fl. (ESA, SPF); idem, F.R. Salimena-Pires \& R.D.V. Braga 21522, 17.VII.1987, fl. (CESJ, ESA); Km 127, CFSC 6599, M.C. Henrique et al., 11.X.1980, fl. (ESA, SPF, UEC); Km 132, CFSC 4776, J. Semir \& M. Sazima, 10.XII.1973, fl. (SP); Km 134, CFSC 6101, A. Furlan \& J.R Pirani, 23.V.1980, fl. (ESA, SP); Km 142, CFSC 9910, R.M. Silva et al., 11.X.1986, fl.fr. (ESA, SPF); Alto do Palácio, CFSC 9887, J.C.C. Gonçalves et al., 12.IX.1986, fl.fr. (ESA, SPF); próximo a estátua do Juquinha, L.S. Kinoshita et al. 00/188, 22.XI.2000, fl. (UEC); próximo à bifurcação para o Morro do Pilar, CFSC 10749, F.R. Salimena-Pires et al., 9.X.1987, fl.fr. (ESA, SPF); idem, V.C. Souza \& C.M. Sakuragui 1968, 5.IX.1992, fl. (ESA); idem, V.C. Souza et al. 11724, 5.VII.1996, fl.fr. (BHCB, ESA, SPF); idem, 19¹3'13"S 4329'57"W, G.O. Romão et al. 741, 742 e 743, 5.VII.2001, fl.fr. (BHCB, ESA, RB, SPF); idem, V.C. Souza et al. 25141 , 25142, 25146, 25148 e 25150, 5.VII.2001, fl.fr. (BHCB, ESA,

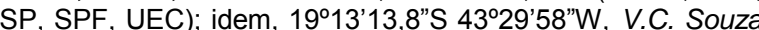
et al. 28656, 28.II.2002, fl.fr. (BHCB, ESA, SPF). Parque Nacional da Serra do Cipó: Serra da Bandeirinha, CFSC 12496, A.M. Giulietti et al., 27.VII.1991, fl.fr. (ESA, SPF); idem, próximo a casa do IBDF, CFSC 10508, I. Cordeiro et al., 9.IX.1987, fl. (ESA, SPF); idem , CFSC 10554-A, C. Kameyama et al., 9.IX.1987, fl. (ESA, SPF); Serra da Salitreira, CFSC 11540, J. Prado et al., 5.VII.1989, fl. (SPF); idem, CFSC 11535, C. Kameyama et al., VII.1989, fl.fr. (SPF); F. Barros 350, 7.IX.1980, fl. (SP). Serra do Cipó: Km 129-134, A.P. Duarte 2044, 4.XII.1949, fr. (RB, UEC); Km 138, A. Brade 14890, s.d., fl. (RB); Morro do Cruzeiro, L.R. Lima et al. 39, 28.VII.1999, fl.fr. (ESA, SPF).

Judd (1984) reconheceu duas variedades com base principalmente no formato e base das folhas. $\mathrm{Na}$ Serra do Cipó foi encontrada apenas $A$. coriifolia var. coriifolia, que se caracteriza por apresentar folhas ovaladas a elípticas e base cordada a arredondada.

Agarista coriifolia var. coriifolia distribui-se pela Cadeia do Espinhaço em Minas Gerais e Bahia, adentrando pelo cerrado e afloramentos rochosos em Goiás e Serra da Mantiqueira em Minas Gerais e São Paulo. Na Serra do Cipó é encontrada em campos rupestres, cerrados de altitude, beiras de matas ou raramente em matas ciliares, sobre solos predominantemente arenosos ou pedregosos não alagáveis. Foi coletada com flores e frutos praticamente $\mathrm{o}$ ano todo.

Essa espécie assemelha-se a $A$. pulchra por apresentar folhas geralmente ovaladas com base cordada. Contudo, diferem quanto ao indumento das folhas, presença de glândula foveolada, ápice foliar e coloração da corola. As folhas de $A$. coriifolia var. coriifolia são esparsamente pubérulas a tomentelas na nervura central, glândulas foveoladas conspícuas e enegrecidas na face inferior, ápice com múcron ca. 1 $\mathrm{mm}$ e corola vermelha ou rosada, enquanto que em $A$. pulchra as folhas são glabras ou esparsamente pubescentes na nervura central, glândulas foveoladas inconspícuas na face inferior, ápice com múcron ca. 2 $\mathrm{mm}$ e corola alva.

É observado que, na Serra do Cipó, Agarista coriifolia juntamente a $A$. glaberrima são as espécies do gênero mais comumente encontradas. Ilustrações em Meisner (1863, sob Leucothoe crassifolia), Kinoshita-Gouvêa (1980 inéd., sob $L$. coriifolia e $L$. pohlii), Judd (1995) e Kinoshita \& Romão (2012).

1.3. Agarista duartei (Sleum.) Judd, J. Arnold Arbor. 65: 338. 1984.

Sin.: Leucothoe duartei Sleum., Bot. Jahrb. Syst. 78: 451. 1959.

Fig. 1. A-C.

Subarbusto, 0,3-0,7 $\mathrm{m}$ alt., ereto. Tricomas simples, alvos, nos ramos, folhas, flores e frutos, raramente ferrugíneos na ráquis; tricomas glandulares ausentes. Ramos pubescentes a tomentosos, glabrescentes, densamente foliados, partes velhas desfoliadas. Folhas alternas ou subopostas, não imbricadas, $\quad(0,7-) 1-4,9(-5,3) \times 0,1-0,3 \quad \mathrm{~cm}$, conduplicadas, rigidamente coriáceas, espessas; pecíolo (1-)2-7 mm compr., robusto, rígido, esparsa ou densamente pubescente; limbo linear, ápice agudo, mucronulado, com glândula apical espesso-alongada, base atenuada, margem inteira, plana ou ligeiramente sobrevoluta, face superior subdensamente pubescente, face inferior glabra ou esparsamente pubescente apenas na nervura central, raramente em todo o limbo, glândulas foveoladas ausentes, nervação reticulódroma, nervuras proeminentes na face inferior. Racemos axilares, bracteados, 2-7-floro; ráquis 0,2$0,8 \mathrm{~cm}$, densamente pubescente a tomentosa; bráctea 1-2 $\mathrm{mm}$ compr., triangular ou linear-filiforme, esparsamente pubescente ou apenas ciliada; bractéolas ca. $1 \mathrm{~mm}$ compr., triangular-setiformes, inseridas na porção basal até a mediana do pedicelo. Flores laxas; pedicelo 2-7 $\mathrm{mm}$ compr., pubescente a tomentoso; cálice 1-2 $\mathrm{mm}$ compr., pubescente na base, nas bordas dos lobos e na face interna; corola urceolada ou cilíndrica, 6-9 $\mathrm{mm}$ compr., alvoesverdeada, creme-amarelada ou avermelhada, glabra, lobos retos ou ligeiramente recurvados; estames 3-4,5 $\mathrm{mm}$ compr., filete densamente tomentoso a viloso, antera lisa; ovário densamente tomentoso, estilete ca. $5,5 \mathrm{~mm}$ compr., glabro. Fruto 4-7 mm diâm., globoso, castanho, pubescente a tomentoso.

Material examinado: Jaboticatubas, Serra do Cipó, Rodovia Lagoa Santa-Conceição do Mato DentroDiamantina: $\mathrm{Km}$ 128, CFSC 4241, N.L. Menezes, 11.VII.1973, fl. (UEC); Km 132, J. Semir 8677, 30.XI.1978, fl. (UEC). Santana do Riacho, Serra do Cipó, Rodovia Belo Horizonte-Conceição do Mato Dentro: Km 114, CFSC 7305, N.L. Menezes, 9.X.1975, fl. (SPF, UEC); Km 116,5, G.O. Romão 536 e 537, 2.XI.2000, fl. (ESA, SPF); idem, 19¹6'15,3"S 43³2'51,5”W, G.O. Romão et al. 895, 913 e 
914, 10.I.2003, fr. (BHCB, ESA, MBM, MO, NY, RB, SPF, UEC, US); idem, Alto do Palácio, G.O. Romão et al. 1104, 5.XII.2004, fl.fr. (BHCB, ESA, SPF); Km 119, Fazenda Cachoeira da Capivara, 19¹4'58,1"S 4332'41"W, G.O. Romão et al. 869, 28.II.2002, fr. (ESA); idem, V.C. Souza et al. 28619, 28.II.2002, fl. (ESA, RB); idem, G.O. Romão \& A.P.T. Dantas 2266, 8IX.2007, fr. (ESA, NY); Km 137, CFSC 9919, N.S. Chukr et al., 12.XII.1986, fl. (ESA, SPF); Km 138, Alto do Palácio, R.M. Harley et al. CFCR 6052, 15.XI.1984, fl. (ESA, SPF); Fazenda Cachoeira da Capivara, 19¹4'57,2"S 4332'58"W, G.O. Romão et al. 905, 10.I.2003, fl.fr. (ESA); Rodovia MG-10, Fazenda Cachoeira da Capivara, G.O. Romão et al. 2445, 5.IV.2010, fr. (ESA); Parque Nacional Serra do Cipó, próxima a estátua do Juquinha, L.S. Kinoshita \& A.O. Simões 00/198, 22.XI.2000, fl. (UEC). Serra do Cipó, Alto do Palácio, estrada para Conceição do Mato Dentro, T.F. Daniel \& N. Hensold 2285, CFCR 3691, 14.II.1982, fr. (SPF); Schwacke 8275, 26.IV.1892, fr. (ESA, RB).

Agarista duartei é endêmica da Serra do Cipó, encontrada em campos rupestres, sobre solos arenosos ou areno-pedregosos frequentemente alagáveis, às vezes entre pedriscos. Foi coletada com flores de outubro a fevereiro e em julho, com frutos de dezembro a abril e em setembro.

De acordo com Judd (1984, 1995), as folhas jovens dessa espécie podem apresentar tricomas glandulares e glândulas foveoladas na face inferior, porém estas características não foram observadas. Essa espécie relaciona-se com $A$. angustissima discutido anteriormente. Ilustrações em Souza \& Lorenzi (2008).

1.4. Agarista eucalyptoides (Cham. \& Schltdl.) G. Don, Gen. hist. 3: 837. 1834.

Sin.: Leucothoe eucalyptoides (Cham. \& Schltdl.) DC., Prodr. 7: 605. 1839.

Fig. 1. I.

Arbusto ou arvoreta, 2-3 m alt., esguio. Tricomas simples, ferrugíneos nas flores e frutos, alvos no cálice; tricomas glandulares ausentes. Ramos glabros, esparsamente foliados. Folhas alternas, não imbricadas, 2,3-7,2(-11,7)x1,2-2,6 cm, planas ou conduplicadas, subcoriáceas, pendentes; pecíolo 12-32 $\mathrm{mm}$ compr., delgado, flexível, glabro; limbo ovalado a lanceolado ou elíptico, raramente oblongo, ápice agudo, obtuso a acuminado, raramente emarginado, mucronulado, com glândula apical espesso-alongada, base arredondada ou obtusa, raramente truncada ou subcordada, margem inteira, plana, ambas as faces glabras, glândulas foveoladas inconspícuas associadas às nervuras secundárias na face inferior, nervação craspedódroma, nervuras ligeiramente proeminentes na face superior e impressas na inferior. Panículas terminais ou racemos axilares, bracteados, 5-13-floro; ráquis 1,2-5,2 cm, esparsa a densamente ferrugíneo-pubescente; bráctea 1-3 mm compr., triangular, ferrugíneo-pubescente ou apenas ciliada; bractéolas 1-2 mm compr., triangular- setiformes, inseridas na porção basal até a mediana do pedicelo. Flores laxas; pedicelo 2-6 mm compr., pubescente; cálice 2-3 mm compr., pubescente apenas nas bordas dos lobos; corola tubulosourceolada ou cilíndrica, 5-8 $\mathrm{mm}$ compr., alvoesverdeada ou amarelada, glabra, lobos retos ou recurvados; estames 3-4 $\mathrm{mm}$ compr., filete subdensamente tomentoso, antera lisa; ovário glabro ou pubescente a tomentoso principalmente na base, estilete ca. $6 \mathrm{~mm}$ compr., glabro. Fruto 4-7 mm diâm., globoso a ovóide, castanho, glabro ou pubescente na base.

Material examinado: Serra do Cipó: $\mathrm{Km}$ 131, A.P. Duarte 2694, 24.IV.1950, fr. (RB); Lapinha, a $19 \mathrm{Km}$ ao norte de Serro, H.S. Irwin et al. 20802, 24.II.1968, fl. (RB).

Material adicional: MINAS GERAIS. Belo Horizonte: Serra do Curral, P.L. Krieger 15486, 28.VIII.1995, fl. (CESJ, ESA); Reserva da Mutuca/COPASA, N.C. Attala et al. 137, 16.XI.1989, fr. (BHCB, ESA). Brumadinho, Retiro das Pedras, 2005'35"S 4359'01'W, A. Barros \& J.R. Stehmann 20, 12.VIII.1997, fl. (BHCB, ESA). São Roque de Minas: Parque Nacional da Serra da Canastra, Garagem de Pedra, J.N. Nakajima et al. 2718, 12.I.2005, fl. (ESA, HUFU); idem, próximo do centro de visitantes, J.N. Nakajima et al. 1344, 25.IX.1995, fl. (HUFU, UEC); idem, próximo a guarita do IBAMA, L. Freitas 716, 25.IX.1999, fl. (UEC). Serra da Moeda, inicio da estrada BR-040, J. Semir et al. 28820, 8.VIII.1993, fl. (UEC). RIO DE JANEIRO, Itatiaia, Brade 14086, IX.1934, fl. (RB, UEC). SÃO PAULO. Campos do Jordão, Parque Estadual do Instituto Florestal, M.J. Robim 636, 3.X.1989, fl. (SP, UEC). São João da Boa Vista, Pico do Gavião, R.R. Rodrigues et al. 373, 7.X.1995, fl.fr. (ESA, UEC).

Agarista eucalyptoides distribui-se pelas regiões montanhosas da Cadeia do Espinhaço na Bahia até os Aparados da Serra no Rio Grande de Sul, adentrando pelo Uruguai. Na Serra do Cipó é encontrada em cerrados de altitude ou no interior de matas de galeria, sobre solos arenosos ou pedregosos não alagáveis. Foi coletada com flores em janeiro, fevereiro e de agosto a outubro, com frutos em abril, outubro e novembro.

Segundo Kinoshita-Gouvêa (1980 inéd.), essa espécie pode apresentar hábito arbóreo, raramente atingindo $8 \mathrm{~m}$ de altura. No aspecto geral da planta, $A$. eucalyptoides e $A$. glaberrima são bastante semelhantes, tanto que alguns autores como Sleumer (1959) consideraram a variedade $A$. eucalyptoides var. glaberrima. Ambas assemelham-se por apresentarem folhas estreito-alongadas e pendentes, geralmente conduplicadas, com pecíolo delgado e flexível e por serem arbustos esguios. Diferem principalmente quanto ao indumento da ráquis da inflorescência e brácteas, que são ferrugíneo-pubescentes em $A$. eucalyptoides, enquanto que em $A$. glaberrima são glabras, às vezes com brácteas ciliadas.

Ilustrações em Marques (1975, sob Leucothoe eucalyptoides), Kinoshita-Gouvêa (1980 inéd., sob $L$. eucalyptoides), Judd (1995) e Mezabarba et al. (2013). 
1.5. Agarista glaberrima (Sleum.) Judd, J. Arnold Arbor. 65: 336. 1984.

Sin.: Leucothoe eucalyptoides (Cham. \& Schltdl.) DC. var. glaberrima Sleum., Bot. Jahrb. Syst. 78: 458. 1959.

Subarbusto a arbusto, 0,5-3 m alt., esguio. Tricomas simples, alvos, nas folhas e flores; tricomas glandulares ausentes. Ramos glabros, esparsamente foliados. Folhas alternas, não imbricadas, 3,8$10,9 \times 0,8-2,5 \mathrm{~cm}$, planas ou mais comumente conduplicadas, subcoriáceas, pendentes; pecíolo 6-35 $\mathrm{mm}$ compr., delgado, flexível, glabro ou subglabro, raro esparsamente pubescente; limbo estreitamente elíptico ou mais frequentemente lanceolado, ápice agudo ou subacuminado, mucronulado, com glândula apical espesso-alongada, base aguda ou obtusa, raramente arredondada, margem inteira, plana, ambas as faces glabras ou raramente pubescente apenas próximo à nervura central da face superior, glândulas foveoladas conspícuas e enegrecidas associadas às nervuras secundárias na face inferior, nervação reticulódroma, nervuras proeminentes em ambas as faces. Panículas ou racemos terminais ou axilares, bracteados, 4-14-floro; ráquis $0,6-4,3 \mathrm{~cm}$, glabra; bráctea ca. $1 \mathrm{~mm}$ compr., triangular-setiforme, ciliada, raramente glabra; bractéolas ca. $1 \mathrm{~mm}$ compr., linearsetiformes, inseridas na porção basal até a mediana do pedicelo. Flores laxas; pedicelo 2-6 $\mathrm{mm}$ compr., glabro; cálice 1-2 mm compr., glabro ou pubescente apenas nas bordas dos lobos; corola cilíndrica ou urceolada, às vezes tubuloso-urceolada, $5-10 \mathrm{~mm}$ compr., alva a esverdeada ou creme, raramente rósea, glabra, lobos retos; estames 4,5-6 mm compr., filete subdensamente pubescente a tomentoso nas bordas, antera granulada; ovário glabro, estilete ca. $7,5 \mathrm{~mm}$ compr., glabro. Fruto $4-8 \mathrm{~mm}$ diâm., globoso, castanho, glabro.

Material examinado: Congonhas do Norte, Serra do

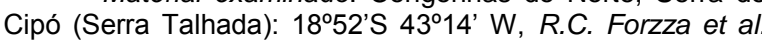
726b, 3.III.1998, fl. (ESA); Retiro do Barbado, 18²'S 434' 'W, CFSC 8424, M.C.E. Amaral et al., 22.IV.1982, fr. (SPF, UEC). Jaboticatubas, Serra do Cipó, Rodovia Lagoa Santa-Conceição do Mato Dentro-Diamantina: $\mathrm{Km} \mathrm{126,} F$. Barros 1337, 2.II.1987, fr. (ESA, SP); Km 127, CFSC 743, J. Semir \& M. Sazima, 7.II.1972, fl. (ESA, SP, UEC); Km 131, CFSC 1248, A.B. Joly et al., 6.III.1972, fl.fr. (ESA, SP, UEC); Km 132, CFSC 756, J. Semir \& M. Sazima, 8.II.1972, fl.fr. (SP); idem, CFSC 5139-A, J. Semir et al., 6.IX.1974, fl.fr. (UEC); Km 138, CFSC 3432, A.B. Joly \& C. Müller, 8.IX.1972, fr. (UEC); Km 139, CFSC 1921, A.B. Joly et al., 17.IV.1972, fr. (UEC); Km 142, CFSC 626, J. Semir et al., 6.II.1972, fl. (UEC); idem, CFSC 4874, J. Semir \& D.A. Lima, 10.XII.1973, fl. (SP); Alto da Serra Dourada, N. Roque et al. 111, 12.Il.1996, fl. (ESA, SPF). Santana do Pirapama: distrito de São José da Cachoeira, 1900'58,7"S 4344'57,7'W, G.O. Romão et al. 1966, 21.II.2007, fl. fr. (ESA, K, M, RB, UEC); idem, trilha da Senhorinha, 18,9422ㅇ $43,7498^{\circ} \mathrm{W}$, V.C. Souza et al. 32857 e 32864, 19.II.2007, fl. (BHCB, ESA, K, SPF); Fazenda Toucan, trilha João carrinho, G.O. Romão et al. 2404, 28.XI.2009, fr. (ESA, K). Santana do Riacho, Serra do Cipó, Rodovia Belo Horizonte-Conceição do Mato Dentro: $\mathrm{Km}$ 116,5, 19¹6'15,3”S 4332'51,5”W, G.O. Romão et al. 898, 10.I.2003, fl. (ESA); Km 117, próximo à estátua do
Juquinha, G.O. Romão et al. 873, 28.Il.2002, fl.fr. (BHCB, ESA, RB, SP, SPF, UEC); idem, V.C. Souza et al. 28640, 28.Il.2002, fl.fr. (BHCB, ESA, SPF); Km 119, Fazenda

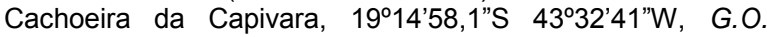
Romão et al. 874, 875 e 876, 28.Il.2002, fl.fr. (BHCB, ESA, RB, SP, SPF, UEC); idem, V.C. Souza et al. 28603, 28.II.2002, fl. (ESA, SPF); Km 126, L.M. Borges 44, 3.II.2006, fl. (SPF); Km 140, CFSC 5979, A. Furlan \& M.G. Sajo, 29.Il.1980, fl. (ESA, SPF); Km 125, CFSC 12073, J.R. Pirani et al., 26.Ill.1991, fr. (ESA, SPF); idem, CFSC 12885, J.R. Pirani et al., 7.III.1992, fl. (ESA, SPF); próximo à Fazenda Boa Vista, CFSC 7821, G.P. Lewis et al., 17.Il.1982, fl. (SP); próximo à bifurcação para o Morro do Pilar, V.C. Souza et al. 10255, 12.I.1996, fl. (BHCB, ESA, RB, SP, SPF, UEC); idem, G.O. Romão et al. 886, 10.I.2003, fl. (ESA, SPF, UEC, US); idem, 19¹3'13"S 4329'57"W, G.O. Romão et al. 744 e 745, 5.VII.2001, fl.fr. (BHCB, ESA, RB, SP, SPF, UEC); idem, V.C. Souza et al. 25140, 5.VII.2001, fl.fr. (ESA, RB, SPF); idem, $19^{\circ} 13^{\prime} 13,8^{\prime \prime}$ 4 4329'58"W, G.O. Romão et al. 860, 28.ll.2002, fl. (ESA); idem, G.O. Romão et al. 1110, 5.XII.2004, fr. (BHCB, ESA, RB, SPF); Alto de Congonhas, N.L. Menezes 1261, 11.Il.1991, fl. (ESA, SPF); estrada para Lapinha, 1908'17'S 4341'41'W, A. Rapini et al. 589, 4.III.1998, fl. (ESA, SPF); Fazenda Cachoeira da Capivara, 19¹4'58"S 4332'41'W, G.O. Romão \& A.P.T. Dantas 2265, 8.IX.2007, fl. (BHCB, ESA, L, SPF, UEC); idem, G.O. Romão et al. 2441, 5.IV.2010, fr. (ESA); a $3 \mathrm{Km}$ da portaria do IBAMA, região das Canelas de Emas Gigantes, M. Pereira \& M. Lucca 994, 8.III.1993, fl.fr. (BHCB, UEC); Vellozia Gigante, L.S. Kinoshita \& K. Matsumoto 00/526, 22.XI.2000, fl. fr. (UEC); RPPN Brumas do Espinhaço, I.R. Andrade et al. 435, 17.V.2012, fl. (UEC). Serra do Cipó, Alto do Palácio, estrada para Conceição do Mato Dentro, T.F. Daniel \& N. Hensold 2278, CFCR 3684, 14.Il.1982, fl. (SPF); E.P. Heringer \& Castellanos s.n., 6.III.1958, fl. (SP 79935); idem, J. Badini \& M. Barreto s.n., 1938, fl. (OUPR 4601); idem, km 131, A.P. Duarte 2688, 24.IV.1950, fr. (RB); idem, a $5 \mathrm{Km}$ da casa do IBAMA, M. Pereira et al. s.n., 14.Il.1995, fl. (BHCB 27260, ESA 76871).

Agarista glaberrima distribui-se na Cadeia do Espinhaço em Minas Gerais. Na Serra do Cipó é encontrada em campos rupestres, sobre solos arenosos não alagáveis, entre pedriscos ou grandes blocos rochosos. Foi coletada com flores e frutos praticamente o ano todo.

Essa espécie relaciona-se com $A$. eucalyptoides discutido anteriormente, e juntamente $\operatorname{com} A$. coriifolia são as espécies do gênero mais comumente encontradas na Serra do Cipó. llustrações em Judd (1995) e Romão et al. (2004).

1.6. Agarista oleifolia (Cham.) G. Don, Gen. hist. 3: 838. 1834.

Sin.: Leucothoe oleifolia (Cham.) DC., Prodr. 7: 605. 1839.

Fig. 1. G.

Subarbusto a arvoreta, $0,7-3 \mathrm{~m}$ alt., ereto. Tricomas simples, alvos ou ferrugíneos, nas folhas e flores; tricomas glandulares robusto-alongados nas flores. Ramos glabros, esparsamente foliados. Folhas alternas ou subopostas, não imbricadas, (3,5-)4,4$13,4 \times 1-2,4 \mathrm{~cm}$, planas, cartáceas; pecíolo $4-9 \mathrm{~mm}$ compr., robusto, rígido, glabro ou esparsamente 
pubescente; limbo elíptico, oblongo ou mais frequentemente lancelolado, ápice agudo ou acuminado, raramente obtuso, mucronulado, com glândula apical espessa, alongado-achatada, base arredondada ou obtusa, raramente aguda, margem inteira, plana ou ligeiramente revoluta principalmente próximo da base, ambas as faces glabras ou esparsamente pubescentes na nervura central, às vezes com glândulas foveoladas conspícuas e enegrecidas associadas às nervuras secundárias na face inferior, nervação reticulódroma, nervuras proeminentes em ambas as faces. Racemos axilares subapicais, bracteados, 4-12-floro; ráquis $2,2-8,8 \mathrm{~cm}$, esparsa a densamente pubescente, frequentemente hirsuto-glandular; bráctea 1-2 mm compr., triangular, raramente linear-setiforme, ciliada; bractéolas ca. 1 $\mathrm{mm}$ compr., linear-setiformes, inseridas na porção basal até a apical do pedicelo. Flores laxas; pedicelo 4-8 mm compr., pubescente ou hirsuto-glandular; cálice 2-4 mm compr., pubescente nas bordas dos lobos, frequentemente hirsuto-glandular na base; corola urceolada, tubuloso-urceolada ou cilíndrica, 7$11 \mathrm{~mm}$ compr., rosada, vermelha ou alvo-esverdeada, glabra, lobos retos ou recurvados; estames 5-6 mm compr., filete esparsamente pubescente nas bordas, antera lisa; ovário subglabro, com poucos tricomas no ápice, estilete ca. $7 \mathrm{~mm}$ compr., glabro. Fruto $4-8 \mathrm{~mm}$ diâm., subgloboso, castanho, glabro.

Material examinado: Jaboticatubas, Serra do Cipó, Rodovia Lagoa Santa-Conceição do Mato DentroDiamantina: Km 126, CFSC 4689, J. Semir \& M. Sazima, 28.X.1973, fr. (ESA, SP, UEC); idem, CFSC 4846, J. Semir \& D.A. Lima, 10.XII.1973, fr. (SP, UEC); estrada da Usina, CFSC 5132, J. Semir et al., 5.IX.1974, fl. (UEC). Santana do Riacho, Serra do Cipó, Rodovia Belo Horizonte-Conceição do Mato Dentro: Km 107, CFSC 7462, J.R. Pirani et al., 4.X.1981, fl.fr. (ESA, SPF, UEC); idem, CFSC 8852 e 8873, E. Forero et al. 7939 e 7960, 7.IX.1980, fl. (SP, SPF); córrego Chapéu de Sol, CFSC 10438, R. Simão, 6.IX.1987, fl.fr. (ESA, SPF); próximo ao Juquinha, 19¹5'29"S 433'04"W, J.A. Lombardi 3212, 1.X.1999, fl. (BHCB, CESJ, ESA); Serra da Bandeirinha, caminho para a Cachoeira das Flores, CFSC 10647a, M.G.L. Wanderley et al., 9.IX.1987, fl.fr. (ESA, SPF); F. Barros 361, 7.IX.1980, fl. (SP). Serra do Cipó: margem do rio das Velhas, Arechavalete s.n., IX.1837, fl. (R, UEC 33750); M.M.N. Braga \& A.L.F. Chaves 369, 4.X.1999, fl. (BHCB, CESJ, ESA, NY, UEC, US).

Judd (1984) reconheceu duas variedades com base no indumento da ráquis da inflorescência e tamanho da corola. Na Serra do Cipó apenas foi encontrada $A$. oleifolia var. oleifolia, que de acordo com Romão \& Souza (2003), caracteriza-se facilmente por apresentar ráquis pubescente. De acordo com Judd (1984) e Kinoshita \& Romão (2011), essa espécie pode apresentar hábito arbóreo, atingindo até $6 \mathrm{~m}$ de altura, entretanto, na Serra do Cipó foram encontrados indivíduos com no máximo $3 \mathrm{~m}$.

Agarista oleifolia var. oleifolia distribui-se desde a Cadeia do Espinhaço na Bahia até as regiões serranas no Paraná, adentrando pelo Brasil-central em Goiás e Mato Grosso. Na Serra do Cipó ocorre no interior ou beira de matas ciliares, sobre solos arenosos alagáveis. Foi coletada com flores em setembro e outubro, com frutos de setembro a dezembro.

Ilustrações em Meisner (1863, sob Leucothoe oleifolia), Kinoshita-Gouvêa (1980 inéd., sob $L$. oleifolia), Judd (1995), Romão \& Souza (2003), Kinoshita \& Romão (2012) e Mezabarba et al. (2013).

1.7. Agarista pulchra (Cham. \& Schltdl.) G. Don, Gen. hist. 3: 837. 1834.

Sin.:Leucothoe pulchra (Cham. \& Schltdl.) DC., Prodr. 7: 604. 1839.

Fig. 1. F.

Arbusto a arvoreta, 0,3-1,5(-4) m alt., às vezes esguio. Tricomas simples, alvos, nos ramos, folhas, flores e frutos; tricomas glandulares ausentes. Ramos glabros ou esparsamente pubescentes, densamente foliados. Folhas alternas, não imbricadas, 2,6-5,4x1,1$2,5 \mathrm{~cm}$, planas, coriáceas; pecíolo $3-8 \mathrm{~mm}$ compr., robusto, rígido, glabro ou pubescente; limbo ovalado, elíptico ou raramente oblongo, ápice agudo a arredondado, mucronado, múcron ca. $2 \mathrm{~mm}$, com glândula apical espesso-alongada, base arredondada ou cordada, margem inteira, plana ou ligeiramente revoluta, ambas as faces glabras ou esparsamente pubescentes na nervura central e geralmente na base do limbo próximo às margens na face superior, glândulas foveoladas inconspícuas associadas às nervuras secundárias na face inferior, nervação reticulódroma, nervuras proeminentes em ambas as faces, às vezes impressas na superior. Panículas ou racemos terminais, bracteados, 5-34-floro; ráquis 2,5$14 \mathrm{~cm}$, glabra ou pubescente; bráctea 1-3 mm compr., triangular, ciliada; bractéolas ca. $1 \mathrm{~mm}$ compr., linearsetiformes ou lanceoladas, inseridas na porção mediana do pedicelo. Flores laxas ou congestas; pedicelo 4-13 $\mathrm{mm}$ compr., glabro ou densamente pubescente; cálice 1-3 mm compr., esparsamente pubescente, às vezes apenas nas bordas dos lobos; corola subcilíndrica a urceolada, 6-10 mm compr., alva, glabra, lobos retos; estames 6-7 mm compr., filete subdensamente pubescente nas bordas, antera granulada na base; ovário glabro ou pubescente, estilete 8-9 mm compr., glabro. Fruto 4-6 mm diâm., globoso, avermelhado a negro, glabro ou esparsamente pubescente.

Material examinado: Jaboticatubas, Rodovia Lagoa Santa-Conceição do Mato Dentro, Km 132, CFSC 248, A.B. Joly et al., 7.VI.1970, fl. (UEC). Serra do Cipó, L. Damazio s.n., s.d., fl. (RB 55030).

Material adicional: BAHIA. Lençóis: Serra do Palmital, Rodovia Lençóis-Seabra a $23 \mathrm{Km}$ a NW de Lençóis, R.M. Harley et al. CFCR 14152, 16.II.1994, fr. (ESA, SPF); estrada entre a Rodovia BR-242 e Lençóis, $12^{\circ} 32^{\prime} 55^{\prime \prime S} 41^{\circ} 22^{\prime} 37^{\prime \prime W}$, J.P. Souza et al. 6267, 20.VII.2006, fl.fr. (ESA, HUEFS, NY, UEC). Mucugê, a $3-5 \mathrm{Km}$ da cidade em direção a Palmeiras, 1300'21"S 4123'22"W, R.M. Harley et al. CFCR 14291, 20.II.1994, fl. (ESA, SPF). Rio de Contas: arredores do povoado de Mato Grosso, $13^{\circ} 28^{\prime} S 41^{\circ} 50^{\prime \prime} \mathrm{W}, \mathrm{R}, \mathrm{M}$, Harley et al. 25368, 24.X.1988, fl. (ESA, SPF); idem, 13²8'22"S 
41950'26"W, V.C. Souza et al. 26035, 15.VII.2001, fr. (ESA, MBM, UEC); idem, $13^{\circ} 28^{\prime} 22^{\prime \prime} S 41^{\circ} 50^{\prime} 26^{\prime \prime} \mathrm{W}$, G.O. Romão et al. 763, 15.VII.2001, fr. (ESA, SP). MINAS GERAIS. Caeté, Serra da Piedade, $19^{\circ} 49^{\prime} S 43^{\circ} 40^{\prime} \mathrm{W}$, G.O. Romão \& A.P.T. Dantas 2259, 7.IX.2007, fr. (BHCB, ESA, L, UEC). Lavras Novas, Serra do Trovão, G.O. Romão \& A.P.T. Dantas 2228, 2229 e 2230, 3.IX.2007, fl.fr. (BHCB, ESA, MBM, OUPR, RB, SPF, UEC). Ouro Branco, Serra de Ouro Branco, estrada para Ouro Preto, G.O. Romão \& A.P.T. Dantas 2168 e 2169 2.IX.2007, fl.fr. (BHCB, ESA, M, UEC). Santa Bárbara, Parque Natural da Serra do Caraça, trilha para a Gruta de Lourdes, G.O. Romão \& A.P.T. Dantas 2252 e 2253 6.IX.2007, fl.fr. (BHCB, ESA, G, K, NY, RB, SPF, UEC).

Agarista pulchra distribui-se desde a Cadeia do Espinhaço na Bahia até a Serra da Mantiqueira em São Paulo e Rio de Janeiro. Na Serra do Cipó, é encontrada em campos rupestres, entre blocos rochosos ou sobre solos pedregosos não alagáveis. Foi coletada com flores de junho a outubro e em fevereiro, com frutos em fevereiro, julho e setembro.

Essa espécie relaciona-se com $A$. coriifolia var. coriifolia, comodiscutido anteriormente. llustrações em Kinoshita \& Romão (2012).

1.8. Agarista virgata Judd, J. Arnold Arbor. 65: 319. 1984.

Fig. 1. D-E.

Subarbusto a arbusto, 0,3-0,6 $\mathrm{m}$ alt., base procumbente. Tricomas simples, alvos, nas brácteas e flores; tricomas glandulares alongados, finos ou robustos, patentes, nos ramos, folhas e flores. Ramos esparsamente hirsuto-glandulares, densamente foliados. Folhas alternas, imbricadas, 0,7-3(-3,5)x0,52,2 cm, planas, coriáceas; pecíolo 1-2 mm compr., robusto, rígido, esparsamente hirsuto-glandular; limbo largamente ovalado ou elíptico a suborbicular, ápice arredondado ou obtuso, mucronulado, com glândula apical espesso-alongada, base cordada, raramente arredondada, margem subinteira a serrilhada, plana, esparsamente ciliado-glandular, ambas as faces esparsamente hirsuto-glandulares, raro esparsamente pubescente na base da nervura central da face superior, glândulas foveoladas conspícuas e enegrecidas associadas às nervuras secundárias na face inferior, nervação reticulódroma, nervuras proeminentes em ambas as faces. Panículas ou racemos terminais ou axilares subapicais, bracteados, 6-44-floro; ráquis $1,3-9,5 \mathrm{~cm}$, densamente hirsutoglandular; bráctea 1-4 $\mathrm{mm}$ compr., triangular a rômbica, ciliada e esparsamente hirsuto-glandular; bractéolas 1-2 $\mathrm{mm}$ compr., linear-setiformes ou lanceoladas, inseridas na porção mediana até a apical do pedicelo. Flores congestas; pedicelo 2-4 mm compr., hirsuto-glandular; cálice 1-3 mm compr., pubescente e esparsamente hirsuto-glandular na base; corola cilíndrica ou tubuloso-urceolada, 6-9 mm compr., espessada, alva, creme ou verde-amarelada, glabra, lobos retos ou ligeiramente recurvados; estames 5-5,5 $\mathrm{mm}$ compr., filete pubescente a tomentoso nas bordas, antera lisa; ovário glabro, estilete ca. 6,5 mm compr., glabro. Fruto $5-9 \mathrm{~mm}$ diâm., subgloboso, castanho, glabro.

Material examinado: Jaboticatubas, Serra do Cipó, Rodovia Lagoa Santa-Conceição do Mato DentroDiamantina: Km 114, CFSC 5203, J. Semir et al., 8.IX.1974, fl. (UEC). Santana do Riacho, Serra do Cipó, Rodovia Belo

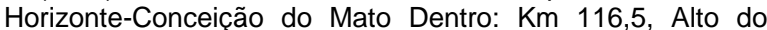
Palácio, G.O. Romão et al. 1105, 5.XII.2004, fr. (BHCB, ESA, $\mathrm{RB}, \mathrm{SP}, \mathrm{SPF}, \mathrm{UEC}$ ); próximo à bifurcação para o Morro do Pilar, 19॰13'13"S 4329'57'W, G.O. Romão et al. 740, 746 e 747, 5.VII.2001, fl.fr. (BHCB, ESA, MBM, RB, SP, SPF, UEC); idem, V.C. Souza et al. 25144 e 25149, 5.VII.2001, fl. (BHCB, ESA, SP, SPF); RPPN Brumas do Espinhaço, M.G.C. Fernandes et al. s.n., 12.IX.2012, fl. (UEC 171273); Vellozia Gigante, L. S. Kinoshita \& K. Matsumoto 00/524, 22.XI.2000, fl. (UEC). Serra do Cipó: $\mathrm{Km}$ 131, A.P. Duarte 2682, 24.IV.1950, fl.fr. (RB); Km 134, M. Barreto \& Brade 1238, 15.IV.1935, fr. (RB); Km 140, quase na vertente para o Morro do Pilar, A.P. Duarte 8098, 22.VI.1964, fl. (ESA, RB); bifurcação Conceição do Mato Dentro-Morro do Pilar, a

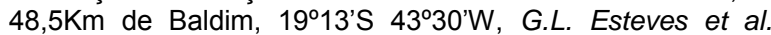
CFCR 15470, 20.IX.1990, fl. (SPF); Retiro do Alto do Palácio, F. Barros 2761, 1.V.1993, fl. (ESA, SP).

Agarista virgata é endêmica da Serra do Cipó, onde pode ser encontrada em campos rupestres, geralmente entre pedriscos e sobre solos arenosos não alagáveis. Foi coletada com flores de abril a julho, em setembro e novembro, com frutos em abril, julho e dezembro.

Essa espécie é facilmente distinta das demais por apresentar folhas imbricadas, com margem subinteira a serrilhada, além de tricomas glandulares alongados e patentes, presentes nos ramos, folhas e flores. Ilustrações em Judd (1984, 1995).

\section{Gaylussacia Kunth}

Subarbustos a arbustos, raramente arvoretas ou árvores, eretos ou procumbentes, copa virgada, fastigiada ou corimboso-ramificada. Folhas alternas ou subopostas, em geral imbricadas, cartáceas a rigidamente coriáceas, raramente decíduas, abertas, concolores ou discolores; pecíolo robusto; limbo com margem inteira ou serreada a crenulada, plana a fortemente revoluta, geralmente com glândulas apicais e marginais, glabro a viloso, geralmente híspido, tricomas simples ou glandulares, glândulas minutas clavadas, capitadas, punctadas até discóides. Inflorescência em panícula ou racemo, bracteada na base do eixo; bráctea 1, geralmente foliácea e vistosa, inserida na base do pedicelo; bractéolas 2, inseridas da base até o ápice do pedicelo. Flores 5-meras, bissexuadas, diplostêmones; cálice conato na base, não carnoso; corola gamopétala, urceolada, tubulosa, cilíndrica ou campanulada, alva, rosada ou vermelha; estames 10, iguais entre si, eretos, filetes retos, achatados, anteras bífidas, dorsifixas, deiscência poricida ou por pequena fenda apical introrsa, teca longo-tubulosa; disco nectarífero circular, dilatado; ovário ínfero, pseudo 10-locular, 1 óvulo por lóculo. Nuculânio globoso a ovóide, com 10 pirênios, 
comumente costado quando imaturo; sementes lenticulares, umbílico-punctiformes.

O gênero é constituído por 54 espécies, distribuídas pela porção subtropical atlântica da América do Norte e na América do Sul tropical e subtropical, sendo completamente ausente na América Central (Kinoshita-Gouvêa 1980 inéd.; Kinoshita 1995).
No Brasil, estão relacionadas 43 espécies ocorrendo em restingas, campinaranas, carrascos e principalmente campos rupestres da Cadeia do Espinhaço até os campos de altitude nas regiões Sul e Sudeste, adentrando pelos afloramentos rochosos situados no Brasil-central (Kinoshita 1996; Kinoshita \& Romão 2010; Romão 2001 inéd.). Na Serra do Cipó são encontradas 17 espécies.

\section{Chave para as espécies}

1. Tricomas glandulares presentes nos ramos, folhas, ráquis da inflorescência, flores ou frutos.

2. Folhas imbricadas, alternas a subopostas, com base frequentemente cordada 2.16. G. virgata

2'. Folhas não imbricadas, alternas, com base arredondada, aguda ou obtusa.

3. Nervação foliar reticulódroma, nervuras marcadamente elevado-proeminentes na face inferior; ápice do limbo com glândula apical umbilicada.....

3'. Nervação foliar broquidódroma ou eucamptódroma, nervuras proeminentes ou impressas na face inferior; ápice do limbo com glândula apical achatada, alongada, capitada ou raramente depresso-subumbilicada.

4. Indumento dos ramos provido apenas de tricomas simples, tricomas glandulares ausentes nos ramos.

5. Face superior das folhas bulada 2.11. G. pulchra

5'. Face superior das folhas não bulada.

6. Margem das folhas inteira, revoluta 2.5. G. luizae

6'. Margem das folhas serrilhada a crenulada próximo do ápice, plana a ligeiramente revoluta geralmente próximo da base.

7. Folhas concolores; limbo ovalado ou elíptico, raramente oblongo; bráctea com glândula apical espessa; cálice hispídulo-glandular na base e bordas dos lobos 2.10. G. pseudociliosa

7'. Folhas discolores; limbo estreitamente elíptico ou obovado a oblanceolado ou oblongo; bráctea desprovida de glândula apical espessa; cálice hispídulo-glandular apenas nas bordas dos lobos.

8. Corola campanulada ou cilíndrica, glabra ou pubescente nos ângulos; ráquis 1,9-9,6 $\mathrm{cm}$ de comprimento, com flores laxas....

8'. Corola urceolada ou tubuloso-urceolada, glabra; ráquis $0,5-2,4 \mathrm{~cm}$ de comprimento, com flores congestas.

4'. Indumento dos ramos provido de tricomas simples e glandulares.

9. Folhas subcoriáceas; bráctea de 4-6 $\mathrm{mm}$ compr.

2.7. G. montana

9'. Folhas rigidamente coriáceas; bráctea 5-13 mm compr.

10. Face superior das folhas não bulada; corola vermelha, subcampanulada

10'. Face superior das folhas bulada; corola alva, tubuloso-urceolada a cilíndrica

2.14. G. rugosa

1'. Tricomas glandulares ausentes.

11. Ramos glabros, raramente subglabros.

12. Limbo foliar linear-aciculado, $0,1-0,2 \mathrm{~cm}$ larg.

2.9. G. pinifolia

12 '. Limbo foliar elíptico, obovado, oblongo ou oblanceolado, raramente suborbicular, $0,7-3,3 \mathrm{~cm}$

larg.

13. Folhas rigidamente coriáceas; ápice dos lobos do cálice com glândula espesso-calosa

13'. Folhas cartáceas, subcoriáceas ou coriáceas; ápice dos lobos do cálice desprovidos de glândula calosa.

14. Flores laxas; corola tubuloso-urceolada, cilíndrica ou raramente campanulada, geralmente alva; pedicelo 8-19(-21) mm compr.; folhas concolores

14'. Flores congestas; corola urceolada, coccíneo-vermelha; pedicelo 6-12 mm compr.; folhas discolores

2.8. G. oleifolia

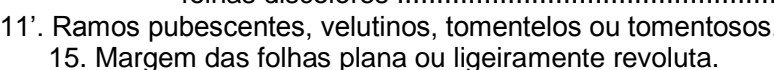

16. Folhas imbricadas, 0,3-1,1(-1,4) cm compr., ovaladas a elípticas

16'. Folhas não imbricadas, 1,2-3,6 cm compr., estreitamente oblanceoladas ou linearoblongas

15. Margem das folhas fortemente revoluta a quase totalmente enrolada.

17. Folhas com glândula apical depresso-capitada, nervação broquidódroma, nervuras proeminentes na face inferior

15. G. salicifolia Folhas com glândula apical espesso-umbilicada, nervação reticulódroma, nervuras marcadamente elevado-proeminentes na face inferior

2.1. G. centunculifolia .. 2.4. G. incana

2.3. G. cinerea 
2.1. Gaylussacia centunculifolia Sleum., Bot. Jahrb. Syst. 86: 377. 1967.

Sin.: Gaylussacia duartei Sleum, Bot. Jahrb. Syst. 86: 363. 1967, syn. nov.

Fig. 2. G.

Subarbusto, 0,2-0,3 $\mathrm{m}$ alt., ereto, virgado. Tricomas simples, alvos, nos ramos, folhas, flores e geralmente frutos; tricomas glandulares ausentes; glândulas capitadas sésseis, rubro-nigrescentes nas folhas e flores, rubro-amareladas na corola. Ramos densamente pubescentes, densamente foliados, ramos velhos geralmente desfoliados. Folhas alternas a subopostas, imbricadas, 0,3-1,1(-1,4) x0,2-0,5(-0,8) $\mathrm{cm}$, subcoriáceas, concolores; pecíolo 1-2 mm compr., densamente pubescente; limbo ovalado a elíptico, ápice agudo ou acuminado, submucronulado, com glândula apical capitada, base arredondada ou subcordada, margem inteira, plana ou ligeiramente revoluta, ambas as faces esparsamente pubescentes, principalmente na base e nervura central da face inferior, glandulosas, nervação broquidódroma, nervuras ligeiramente proeminentes. Racemos axilares ou terminais, 3-4-floro, raramente flores solitárias; ráquis $0,3-1,6(-2,4) \mathrm{cm}$, densamente pubescente, glandulosa; bráctea às vezes foliácea, 23(-5) mm compr., rômbica, pubescente, glandulosa; bractéolas 1-2 $\mathrm{mm}$ compr., linear-lanceoladas ou rômbicas, inseridas na base do pedicelo. Flores congestas; pedicelo 2-4 mm compr., pubescente e glanduloso; hipanto densamente pubescente, glanduloso; cálice ca. $2 \mathrm{~mm}$ compr., pubescente, glanduloso; corola tubuloso-urceolada ou campanulada, 3-4 $\mathrm{mm}$ compr., alva ou rosada, esparsamente pubescente nos ângulos, glandulosa, lobos retos ou recurvados; estames 1,5-2 $\mathrm{mm}$ compr., filete esparsamente pubescente, antera lisa; disco nectarífero glabro; estilete 1-1,5 mm compr., glabro. Fruto 2-4 mm diâm., depresso-globoso, esverdeado, glabro ou pubescente.

Material examinado: Jaboticatubas, Serra do Cipó, Rodovia Lagoa Santa-Conceição do Mato DentroDiamantina: Km 142, J. Semir \& M. Sazima 531, 14.XII.1971, fl.fr. (ESA, SP, UEC). Santana do Riacho, Serra do Cipó, Rodovia Belo Horizonte-Conceição do Mato Dentro: bifurcação para o Morro do Pilar, G.O. Romão et al. 881, 882, 883, 908, 909 e 910, 10.I.2003, fl.fr. (BHCB, ESA, RB, SP, SPF, UEC); idem, $19^{\circ} 13^{\prime} 13,8^{\prime \prime}$ S $43^{\circ} 29^{\prime} 58^{\prime \prime W}$, G.O. Romão et al. 862, 863 e 864, 28.II.2002, fr. (BHCB, ESA, RB, SP, SPF, UEC); idem, G.O. Romão \& A.P.T. Dantas 2268, 8.IX.2007, st. (ESA); idem, $19^{\circ} 13^{\prime} 13,3^{\prime \prime} S 43^{\circ} 29^{\prime} 58,1^{\prime \prime} \mathrm{W}$, G.O. Romão et al. 2527, 7.IV.2010, fr. (ESA, MBM, NY, RB, UEC, US); idem, V.C. Souza et al. 28657, 28.Il.2002, fr. (BHCB, ESA, SPF). Serra do Cipó, estrada de Conceição do Mato Dentro, A.P. Duarte 2376, 12.XII.1949, fl. (LIL, RB).

Gaylussacia centunculifolia é endêmica da Serra do Cipó e encontrada até o momento, apenas no topo de morros próximos à bifurcação para o Morro do Pilar, caracterizando um possível microendemismo. Ocorre em campos rupestres sobre solos arenosos não alagáveis, entre pedriscos no topo de morros. Foi coletada com flores em dezembro e janeiro, com frutos de dezembro a fevereiro e em abril.

Provavelmente em função do microclima, este tipo de distribuição em topos de morros é compartilhado com cinco outras espécies do gênero, das quais Gaylussacia cinerea e G. pinifolia ocorrem na Serra do Cipó.

Essa espécie é facilmente distinta das demais por apresentar as menores folhas e flores dentre todas as espécies do gênero, visto que apresenta folhas de 3-11(-14) $\times 2-5(-8) \mathrm{mm}$, que ainda são imbricadas e com margem inteira e corola de $3-4 \mathrm{~mm}$ de comprimento. No aspecto geral da planta, assemelhase a G. virgata por apresentarem copa virgada e base da planta ereta, ramos densamente foliados e folhas imbricadas, mas diferem quanto ao tamanho das folhas e à presença de tricomas glandulares. Em G. centunculifolia são observadas folhas muito menores e ausência de tricomas glandulares, enquanto que $G$. virgata possui folhas $1,1-2,2 \times 0,6-1,3 \mathrm{~cm}$ e tricomas glandulares amarelados presentes nos ramos e folhas.

Sleumer (1967) reconheceu distintamente Gaylussacia duartei e G. centunculifolia, baseado em diferenças no indumento do caule, formato e dimensão das folhas, além do tamanho da ráquis da inflorescência. Contudo, após uma criteriosa análise dos materiais-tipo, conclui-se que representam uma única espécie, visto que foi constatada uma variação gradativa dos caracteres morfológicos utilizados por Sleumer (1967), sendo aqui sinonimizada sob o nome legítimo Gaylussacia centunculifolia Sleum., como já havia referido Kinoshita-Gouvêa (1980 inéd.) e Romão (2011 inéd.). llustrações em Romão (2011 inéd.).

2.2. Gaylussacia ciliosa Meisn. in Mart., FI. bras. 7: 146.1863.

Fig. 2. A.

Subarbusto, 0,15-0,3 m alt., procumbente. Tricomas simples, alvos, nos ramos, folhas, ráquis e brácteas; tricomas glandulares fino-alongados, ferrugíneos, nos ramos, folhas, flores e frutos; glândulas clavadas ou capitado-sésseis, nigrescentes nas folhas. Ramos pubérulos a pubescentes e esparsamente híspido-glandulares, esparsamente foliados, ramos velhos desfoliados. Folhas alternas, não imbricadas, $1,6-3,5 \times 0,5-1,6 \mathrm{~cm}$, rigidamente coriáceas, espessas, discolores; pecíolo 2-3 mm compr., pubescente e híspido-glandular; limbo oblanceolado, elíptico ou oblongo, raramente ovalado, ápice arredondado ou agudo, mucronulado, com glândula apical espesso-alongada, base arredondada ou aguda, margem inteira, plana ou revoluta, ciliadoglandular, face superior não bulada, ambas as faces híspido-glandulares, pubérula a pubescente na nervura central na face superior, glandulosas, nervação eucamptódroma, nervuras impressas em ambas as faces. Racemos axilares subapicais, 6-10(24)-floro; ráquis 3-9,3 cm compr., densamente pubescente e esparsamente híspido-glandular; bráctea 5-13 mm compr., foliácea, elíptica a rômbica, 


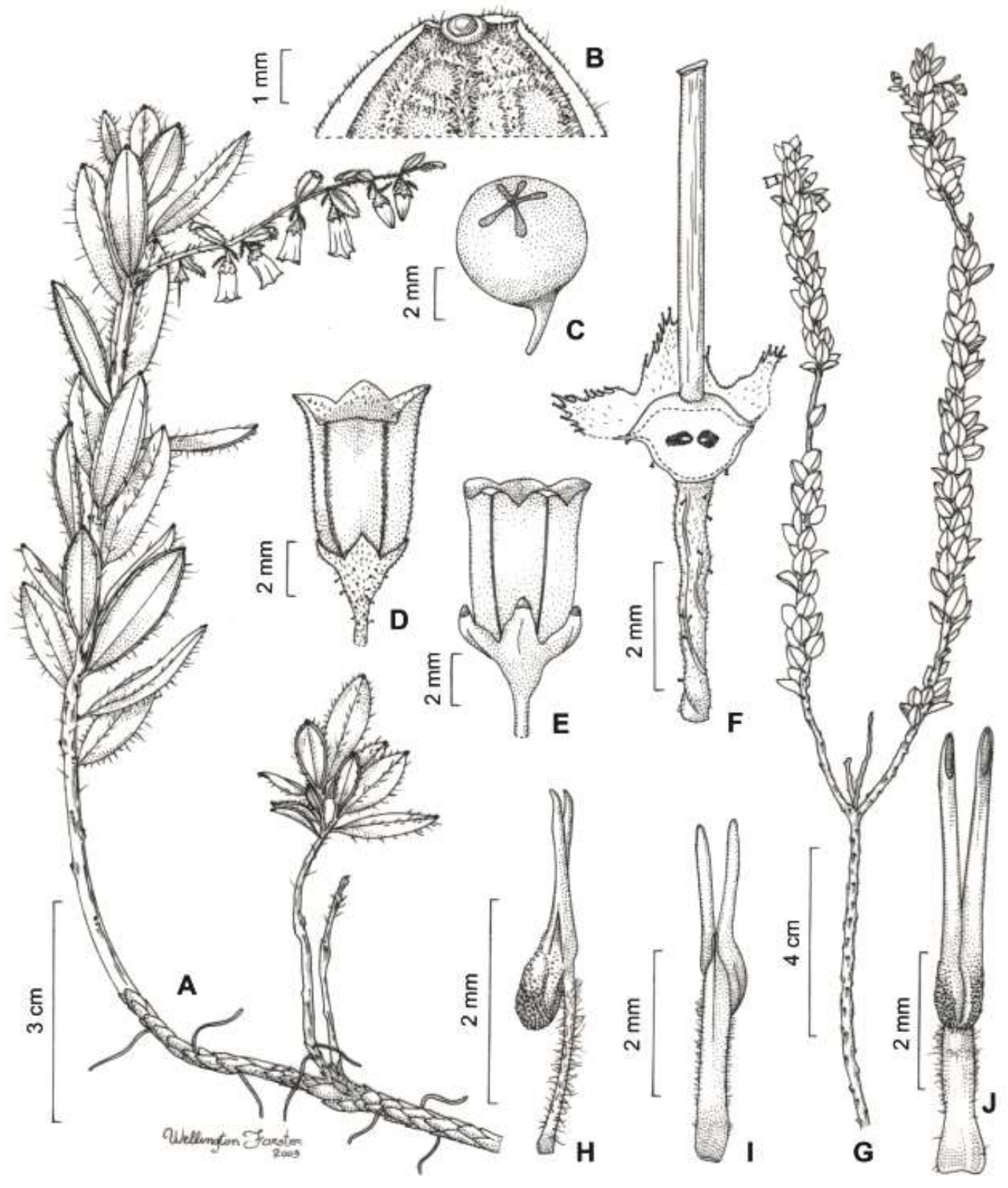

Fig. 2- Gaylussacia. A. G. ciliosa (Schwacke 8284): A. Ramo florido. B. G. reticulata (A.M. Giulietti et al. CFSC 9357): B. Ápice foliar com glândula apical espessa e umbilicada. C. G. salicifolia (G.O. Romão et al. 975): C. Nuculânio maduro. D. G. incana (G.O. Romão 902): D. Flor com corola campanulada. E. G. riedelii (V.C. Souza et al. 25143): E. Flor com corola tubulosocampanulada. F. G. vitis-ideae (G.O. Romão et al. 892): F. Ovário ínfero e tricomas glandulares nos bordos do cálice. G. G. centunculifolia (G.O. Romão et. al. 881): G. Ramo florido. H. G. virgata (J.R. Pirani et. al. CFSC 8015): H. Vista lateral do estame. I. G. pinifolia (V.C. Souza et al. 8213): I. Vista dorsal do estame. J. G. rugosa (B. Stannard et. al. CFCR 5991): J. Vista frontal do estame. 
ciliada e híspido-glandular, com glândula apical espessa; bractéolas ca. $4 \mathrm{~mm}$ compr., lineares, inseridas da base até o ápice do pedicelo. Flores laxas; pedicelo 2-4 mm compr., pubescente e híspidoglandular; hipanto esparsamente híspido-glandular; cálice ca. $2 \mathrm{~mm}$ compr., esparsamente híspidoglandular nas bordas dos lobos, desprovidos de glândula apical-calosa; corola subcampanulada, ca. 5 $\mathrm{mm}$ compr., vermelha, esparsamente híspidoglandular, lobos retos; estames ca. $4 \mathrm{~mm}$ compr., filete densamente setoso, antera lisa; disco nectarífero glabro; estilete 4-4,5 mm compr., glabro. Fruto ca. 4 mm diâm., globoso, negro a avermelhado, esparsamente híspido-glandular.

Material examinado: Congonhas do Norte, norte da Serra do Cipó, Serra Talhada: estrada pela Serra do João Camilo rumo ao Rio Preto, $18^{\circ} 15^{\prime} 19^{\prime \prime S} 43^{\circ} 44^{\prime} 55^{\prime \prime W}$, J.R. Pirani et al. 5182, 20.I.2004, fl. (SPF); estrada para

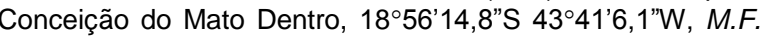
Calió et al. 196 e 197, 20.I.2007, fl.fr. (SPF). Serra do Cipó, Schwacke 8284, 22.IV.1892, st. (ESA, RB).

Gaylussacia ciliosa está distribuída na Cadeia do Espinhaço, entre as regiões ao norte da Serra do Cipó e Planalto Diamantina, Minas Gerais. Na Serra do Cipó ocorre em campos rupestres, sobre solos arenosos provavelmente não alagáveis. Foi coletada com flores e frutos em janeiro.

Quanto à presença de folhas rigidamente coriáceas e tricomas glandulares muito longos (2-3 $\mathrm{mm}$ ), essa espécie relaciona-se com $G$. rugosa, mas diferem quanto à densidade do indumento glandular nos ramos, superfície das folhas, além de formato, cor e tamanho da corola. Em G. ciliosa os ramos são esparsamente híspido-glandulares, folhas com a face superior não bulada e corola subcampanulada, vermelha, ca. $5 \mathrm{~mm}$ de comprimento, enquanto que $G$. rugosa possui ramos subdensamente híspidoglandulares, face superior das folhas bulada e corola tubuloso-urceolada a cilíndrica, alva, de 8-10 mm.

No aspecto geral da planta, essa espécie assemelha-se bastante a $G$. pseudociliosa e $G$. riedelii, mas diferem quanto ao indumento do ramo e margem das folhas. Observa-se que em $G$. ciliosa os ramos são pubérulos a pubescentes e esparsamente híspido-glandulares e a margem das folhas é inteira e ciliado-glandular, já G. pseudociliosa apresenta ramos glabros a pubescentes e margem foliar subcrenulada a serrilhada próximo do ápice, glabra ou raramente ciliado-glandular, enquanto que em $G$. riedelii os ramos são glabros ou subglabros e margem inteira ou serrilhada próximo do ápice e glabra.

De acordo com Kinoshita-Gouvêa (1980 inéd.), trata-se de uma espécie muito rara e jamais foi observada em campo pelos autores do presente trabalho. Ilustrações em Romão (2011 inéd.).
2.3. Gaylussacia cinerea Taub., Bot. Jahrb. Syst. 17: 511. 1893.

Subarbusto, 0,1-0,5 m alt., ereto ou procumbente. Tricomas simples, alvos-cinéreos, nos ramos, folhas, flores e frutos; tricomas glandulares ausentes; glândulas amareladas, clavadas ou capitadas, subsésseis ou pediceladas nos ramos, apenas capitadas nas folhas, flores e frutos. Ramos pubescentes a densamente tomentosos, velutinos, glandulosos, densamente foliados, ramos velhos geralmente desfoliados. Folhas alternas, não imbricadas, 0,6-1,9(-2,3)x0,2-0,9 cm, coriáceas, discolores; pecíolo 1-2 $\mathrm{mm}$ compr., densamente pubescente a tomentoso; limbo estreitamente elíptico, oblongo ou obovado, ápice arredondado, mucronulado, com glândula apical depresso-capitada, recurvada, base aguda, raramente arredondada, margem inteira, fortemente revoluta a quase totalmente enrolada, ambas as faces densamente tomentosas, velutinas, glandulosas, nervação broquidódroma, nervuras impressas na face superior, proeminentes na inferior. Racemos axilares subapicais, 4-6-floro; ráquis 0,8-2,3 cm compr., densamente tomentosa, glandulosa; bráctea 3-6 mm compr., ovalada a rômbica, densamente tomentosa, velutina, glandulosa; bractéolas 2-3 mm compr., oblanceoladas ou lineares, inseridas da base até 0 ápice do pedicelo. Flores congestas; pedicelo 1-2(-4) $\mathrm{mm}$ compr., densamente tomentoso, glanduloso; hipanto densamente velutino-tomentoso, glanduloso; cálice 1-2 mm compr., densamente tomentoso, glanduloso; corola tubuloso-campanulada, 4-6 mm compr., alva, subdensamente velutino-tomentosa, glandulosa, lobos retos; estames 2-3,5 mm compr., filete densamente pubescente a tomentoso, glanduloso, antera lisa; disco nectarífero esparsamente pubescente ou tomentelo; estilete 3-4,5 $\mathrm{mm}$ compr., glabro. Fruto 3-5 mm diâm., depressogloboso ou ovóide, costado, negro ou castanho, pubescente a tomentoso, às vezes glanduloso.

Material examinado: Congonhas da Serra, Serra do Cipó, A. Glaziou 19576 e 19578, IX.1892, fl.fr. (BR, C, F, G, K, L, LE, P). Congonhas do Norte, Serra do Capão Grande, 1855'40,9"S 4341'32"W, F.N. Costa et al. 779, 24.IV.2004, fl. (DIAM, SPF); norte da Serra do Cipó, Serra Talhada; $18^{\circ} 51^{\prime}$ 'S 434' W, CFSC 8346, A. Furlanet al., 21.IV.1982, fl.fr. (ESA, NY, SPF); $18^{\circ} 52^{\prime} \mathrm{S} 43^{\circ} 44^{\prime} \mathrm{W}$, A. Rapini et al. 525,

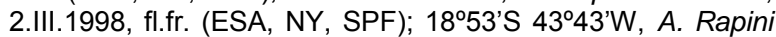
et al. 545, 2.III.1998, fl.fr. (ESA, SPF); $18^{\circ} 52^{\prime}$ S 431'', R.C. Forzzaet al. 722, 3.III.1998, fl.fr. (ESA, SPF); estrada para

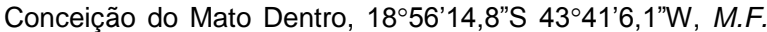
Calió et al. 194, 3.II.2009, fl. (SPF); idem, 1856'23,4"S 4340'55,7'W, L.M. Borges et al. 324, 3.II.2009, fr. (SPF); idem, $18^{\circ} 56^{\prime} 38,4^{\prime \prime} S 43^{\circ} 40^{\prime} 54^{\prime \prime W}$, L.M. Borges et al. 333, 3.Il.2009, fl.fr. (SPF); Serra do Cipó, Serra do Joaquim Gomes, estrada para o rio Preto, $18^{\circ} 15^{\prime} 19^{\prime \prime} \mathrm{S} 43^{\circ} 44^{\prime} 55^{\prime \prime} \mathrm{W}, R$. 
Mello-Silva et al. 2401, 20.I.2004, fl.fr. (ESA, SPF); idem, Serra do João Camilo, rio Preto, 18 ${ }^{\circ} 50^{\prime} 26^{\prime \prime} S 43^{\circ} 44^{\prime} 53^{\prime \prime W}$, J.R. Pirani et al. 5160, 19.I.2004, fl. (ESA, SPF). Santana do Pirapama, Serra do Cipó: Serra Mineira, Fazenda Inhame, 185'S 4354'W, CFSC 8118,J.R. Pirani et al., 22.III.1982, fl.fr. (CEPEC, MICH, SPF, UEC); Serra do Cipó, Fazenda Inhame, 1855'47,6"S 4347'2,7'W, G.O. Romão et al. 2371, 27.XI.2009, fl.fr. (BHCB, ESA, K, MBM, MO, NY, RB, SPF,

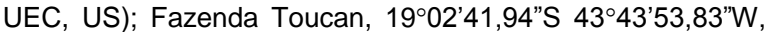
G.O. Romão et al. 2428, 28.XI.2009, fl.fr. (BHCB, ESA, K); Serra da Lapa, Distrito de São José da Cachoeira, trilha da Senhorinha: $18^{\circ} 56^{\prime} 31,9^{\prime \prime S} 43^{\circ} 44^{\prime} 59,3^{\prime \prime W}$, G.O. Romão et al. 2351, 2352, 2353, 2354, 2355, 2356 e 2357, 19.II.2007, fl.fr. (BHCB, ESA, G, HUEFS, K, L, M, MBM, NY, RB, SP, SPF, UB, UEC); idem, $18^{\circ} 56^{\prime} 31,9^{\prime \prime} S 43^{\circ} 44^{\prime} 59,2^{\prime \prime}$, V.C. Souza et al. 32866 e $32867,19.11 .2007$, fl.fr. (BHCB, ESA, K, RB, SPF). Serra do Cipó, Schwacke 8282, 22.IV.1892, fl.fr. (RB).

Gaylussacia cinerea é endêmica da porção norte da Serra do Cipó, ocorrendo em campos rupestres, nas proximidades de topos de morros, sobre solos pedregosos e não alagáveis, comumente entre pedriscos ou blocos rochosos. Foi coletada com flores ou frutos em setembro, novembro e de janeiro a abril.

Essa espécie caracteriza-se por apresentar folhas com margem fortemente revoluta a quase totalmente enrolada, ramos e folhas densamente tomentosas, velutinas, com tricomas alvos-cinéreos. Além disso, a presença de glândulas capitadoamareladas densamente dispostas em todo o limbo na face inferior da folha confere uma coloração ligeiramente amarelada, tanto na planta viva quanto no material herborizado. Ilustrações em Romão (2011 inéd.).

2.4. Gaylussacia incana Cham. \& Schltdl., Linnaea 1: 536. 1826.

Fig. 2. D.

Subarbusto a arbusto, 0,4-1,5 m alt., ereto. Tricomas simples, incano-alvos ou menos comumente ferrugíneos, nos ramos, folhas e flores; tricomas glandulares ausentes; glândulas clavadas ou capitadas subsésseis, amareladas ou rubras a nigrescentes, nas folhas e flores, glândulas imersopunctadas, claro-amareladas nas folhas. Ramos pubescentes a tomentelos, densamente foliados, partes velhas desfoliadas. Folhas alternas a subopostas, não imbricadas, 1,2-3,6x0,3-0,5 cm, cartáceas, discolores; pecíolo 1-3 mm compr., pubescente; limbo estreitamente oblanceolado ou linear-oblongo, ápice agudo ou obtuso, mucronulado, com glândula apical espesso-alongada, base atenuada, margem inteira, plana ou ligeiramente revoluta próximo da base, ambas as faces esparsamente pubescentes próximo das margens e nervura principal, glandulosas e punctadas, nervação broquidódroma, nervuras ligeiramente proeminentes. Racemos axilares subapicais, 5-9-floro; ráquis 2-4,7 cm compr., densamente pubescente, glandulosa; bráctea 3-8 mm compr., oval-lanceolada, pubescente na nervura e bordas, glandulosa; bractéolas 2-3 mm compr., linear-lanceoladas, inseridas na porção mediana ou no ápice do pedicelo. Flores congestas; pedicelo 1-2 mm compr., pubescente e glanduloso; hipanto densamente pubescente a tomentoso, glanduloso na base; cálice 1-2 mm compr., esparsamente pubescente; corola cilíndrica ou campanulada, 4-6 mm compr., alva, pubescente e glandulosa nos ângulos, lobos retos ou ligeiramente recurvados; estames $4,5-5 \mathrm{~mm}$ compr., filete pubescente, antera lisa; disco nectarífero glabro; estilete ca. 5,5 mm compr., glabro. Fruto $3-5 \mathrm{~mm}$ diâm., subgloboso, costado, esverdeado, glabro ou pubescente.

Material examinado: Santana do Riacho, Serra do Cipó, Rodovia Belo Horizonte-Conceição do Mato Dentro: próximo à estátua do Juquinha, G.O. Romão 902, 923, 924 e 925, 10.I.2003, fl.fr. (BHCB, ESA, MBM, RB, SP, SPF, UEC); idem, G.O. Romão et al. 1114 e 1115, 5.XII.2004, fl.fr. (BHCB, ESA, RB, SP, SPF, UEC); RPPN Brumas do Espinhaço, M.G.C. Fernandes et al. 1417, 9.VII.2012, fl. (UEC). Serra do Cipó, M.M.N. Braga \& A.L.F. Chaves 364, 4.X.1991, fl. (BHCB, CESJ, ESA); s.col.,s.d., fl. (VIC 3788). Material adicional: MINAS GERAIS. Capitólio, $20^{\circ} 35^{\prime} 36^{\prime \prime S} 46^{\circ} 17^{\prime} 21^{\prime \prime W}$, L.S. Kinoshita et al. 08/375, 5.XI.2008, fl. (UEC). Joaquim Felício, Serra do Cabral, $B$. Stannard et al. CFCR 6289, 21.XI.1984, fl. (ESA, SPF, UEC). Lavras Novas, Serra do Trovão, G.O. Romão \& A.P.T. Dantas 2221, 3.IX.2007, st. (ESA). Ouro Preto, Serra de Antônio Pereira Samarco, M.C.T.B. Messias et al. 1650, 5.XII.2007, fl. (OUPR, UEC). São Roque de Minas, Parque Nacional da Serra da Canastra: Chapadão do Diamante, J.N. Nakajima et al. 2845, 15.X.1997, fl. (ESA, HUFU); estrada para Sacramento na Garagem de Pedra, 20 13 '54,5"S 46³7'30,8"W, G.O. Romão et al. 2708, 10.IV.2010, fl.fr. (BHCB, ESA, HUEFS, SPF); idem, 20 13'54,7"S $46^{\circ} 37^{\prime} 30,6^{\prime \prime}$, G.O. Romão \& C.D. Feliciano2339 e 2340 4.X.2007, fl. (ESA); idem, J.N. Nakajima \& R. Romero 3268a, 20.XI.2002, fl. (ESA, HUFU); idem, R. Romero et al. 6604, 20.XI.2002, fl. (ESA, HUFU). SÃO PAULO. São João da Boa Vista, Pico do Gavião, R.R. Rodrigues et al. 379, 7.X.1995, fl. (ESA, UEC).

Gaylussacia incana distribui-se pelo domínio cerrado na Serra da Canastra e ao longo da Cadeia do Espinhaço em Minas Gerais e Bahia, raramente adentrando pela Serra da Mantiqueira em São Paulo. $\mathrm{Na}$ Serra do Cipó ocorre em campos rupestres, sobre solos areno-pedregosos não alagáveis. Foi coletada com flores de outubro a abril e em julho, com frutos de janeiro a abril.

Essa espécie é caracterizada por possuir folhas estreitamente oblanceoladas ou linear-oblongas, com glândulas clavadas ou capitadas subsésseis e imersopunctadas em todo o limbo, geralmente amareladas, além de indumento incano-alvo principalmente nos ramos. O indumento alvo-acinzentado nos ramos também é observado em Gaylussacia pallida Cham., que ocorre na Serra do Caparaó e na porção centrosul da Cadeia do Espinhaço, mas não é referida para a Serra do Cipó. Diferem principalmente quanto à margem e glândula apical das folhas, visto que $G$. incana apresenta folhas com margem plana ou ligeiramente revoluta próximo da base e no ápice há 
uma glândula reta, enquanto que G. pallida possui margem ligeira a fortemente revoluta e glândula apical recurvada. Ilustrações em Romão (2011 inéd.).

2.5. Gaylussacia luizae G.O. Romão \& V.C. Souza, Rodriguesia 61(sup.): 43. 2010.

Fig. 3. A-D.

Arbusto, 1-2 m alt., ereto. Tricomas simples geralmente patentes, alvos, nos râmulos, folhas, flores e frutos; tricomas glandulares fino-alongados, alvos, nas folhas; glândulas clavadas, rubras ou nigrescentes nos ramos, flores e frutos, rubro-amareladas nas folhas. Ramos glabros, densamente vilosos a setosos nos râmulos, glandulosos, densamente foliados. Folhas alternas, não imbricadas, (1,9-)2,6-3,6x0,7-1,2 $\mathrm{cm}$, subcoriáceas, discolores; pecíolo 2-4 mm compr., densamente viloso a setoso, glanduloso; limbo obovado a oblanceolado, ápice arredondado a agudo, mucronulado, com glândula apical espesso-alongada, base aguda, margem inteira, revoluta, face superior não bulada, ambas as faces esparsamente vilosas e setosas, esparsamente hispídulo-glandulares na nervura central, glandulosas, nervação broquidódroma, nervuras proeminentes. Panículas ou racemos terminais, 5-11-floro, ou flores solitárias subapicais; ráquis 1,3-3,4 cm compr., densamente vilosa, setosa, glandulosa; bráctea 5-11 mm compr., elíptica a oblanceolada, esparsamente vilosa, glandulosa; bractéolas 1-4 $\mathrm{mm}$ compr., linearsetiformes, inseridas da porção basal até apical do pedicelo. Flores congestas; pedicelo 1-2 mm compr., viloso e glanduloso; hipanto densamente viloso, setoso, glanduloso; cálice ca. $1 \mathrm{~mm}$ compr., esparsamente viloso, setoso, glanduloso; corola urceolada ou tubuloso-urceolada, raramente subcilíndrica, 4-6 mm compr., alva, esparsamente tomentosa nos ângulos, lobos retos ou ligeiramente recurvados; estames ca. $4 \mathrm{~mm}$ compr., filete tomentoso, com glândulas clavadas, antera granulada; disco nectarífero glabro; estilete 4-6 mm compr., glabro. Fruto 2-3 mm diâm., ovóide, esverdeado, densamente viloso, glanduloso.

Material examinado: Jaboticatubas, Serra do Cipó, G. Hatschbach et al. 28872, 18.I.1972, fl. (HB, MBM). Santana do Riacho, Serra do Cipó, Fazenda Boa Esperança, R.C. Forzza et al. 192, 13.Il.1996, fl. (ESA, SPF).

Material adicional: BAHIA. Mucugê, estrada para Guiné, a $23 \mathrm{Km}$ de Mucugê, A. Furlan et al. CFCR 2023, 7.IX.1981, fl.fr. (K, SPF, UEC).

Gaylussacia luizae está restrita à Cadeia do Espinhaço em Minas Gerais e Bahia, especialmente nas regiões da Serra do Cipó e Chapada Diamantina. $\mathrm{Na}$ Serra do Cipó ocorre em campos rupestres ou em borda de matas de galeria, sobre solos arenopedregosos não alagáveis. Foi coletada com flores em janeiro, fevereiro e setembro, com frutos em setembro.

Recentemente descrita, essa espécie caracteriza-se por apresentar folhas obovadas a oblanceoladas, discolores, vilosas e setosas, esparsamente hispídulo-glandulares na nervura central e flores alvas. Ilustrações em Romão \& Souza (2010) e Romão (2011 inéd.).

2.6 Gaylussacia martii Meisn. in Mart., FI. bras. 7: 138. 1863 .

Subarbusto, 0,35-0,7 m alt., ereto. Tricomas simples, alvos, nos ramos, folhas, flores e frutos; tricomas glandulares robusto-alongados, rubroamarelados, no cálice; glândulas clavadas ou capitado-pediceladas, nigrescentes nas folhas e flores, rubras no hipanto. Ramos glabros ou esparsamente pubescentes, densamente foliados, ramos velhos desfoliados. Folhas alternas, não imbricadas, 2,1$5,5 \times 0,7-1,9 \mathrm{~cm}$, subcoriáceas ou coriáceas, ligeiramente discolores; pecíolo 2-5 mm compr., glabro ou densamente pubescente; limbo estreitamente elíptico ou oblongo a oblanceolado, ápice agudo ou obtuso, raramente arredondado, mucronulado, com glândula apical espessa, capitada ou achatada, base aguda, margem serrilhada a crenulada próximo do ápice, às vezes glandulosa entre os dentes, plana a ligeiramente revoluta, face superior não bulada, ambas as faces glabras ou pubescentes na nervura central ou próximo das margens, glandulosas, nervação broquidódroma, nervuras geralmente proeminentes. Racemos axilares subapicais, 8-13-floro; ráquis 1,99,6 cm compr., esparsa a densamente pubérula a pubescente, glandulosa; bráctea foliácea, 4-7 $\mathrm{mm}$ compr., oblanceolada a rômbica, glabra ou pubescente, glandulosa, desprovida de glândula apical espessa; bractéolas 2-3 mm compr., lineares a estreitamente oblanceoladas, inseridas da base até a porção mediana do pedicelo. Flores laxas; pedicelo 2$12 \mathrm{~mm}$ compr., pubérulo ou pubescente, glanduloso; hipanto glabro ou densamente pubescente, glanduloso; cálice 1-2 mm compr., glabro ou esparsamente pubescente e hispídulo-glandular nas bordas dos lobos; corola campanulada ou cilíndrica, 5$8 \mathrm{~mm}$ compr., alva, glabra ou pubescente nos ângulos, raramente glandulosa, lobos retos ou recurvados; estames 5-5,5 $\mathrm{mm}$ compr., filete densamente pubescente, antera lisa; disco nectarífero esparsamente pubescente; estilete ca. $6 \mathrm{~mm}$ compr., glabro. Fruto 4-5 mm diâm., depresso-globoso, esverdeado, costado, glabro ou pubescente.

Material examinado: Jaboticatubas, Serra do Cipó, Rodovia Lagoa Santa-Conceição do Mato DentroDiamantina: Km 127, CFSC 5164, J. Semir et al., 7.IX.1974, fl.fr. (SP); Km 132, CFSC 3104 e 3154, A.B. Joly \& J. Semir, 21.VIII.1972, fl.fr. (ESA, SP, UEC); idem, CFSC 3870, $M$. Sazima \& J. Semir, 16.Il.1973, fl.fr. (SP). Santana do Riacho, Serra do Cipó, Rodovia Belo Horizonte-Conceição do Mato Dentro, $\mathrm{Km}$ 117, próximo à estátua do Juquinha, V.C. Souza et al. 28643, 28.II.2002, fr. (ESA); Km 125, N.M. Castro s.n., 7.VI.1989, fl. (BHCB 21200, HUFU 2273). Serra do Cipó, entre Porto Palácio e Serro, J. Vidal 1211, 1954, fl. (R); W.R. Anderson et al. 36181a, 18.II.1972, fl.fr. (UB). 


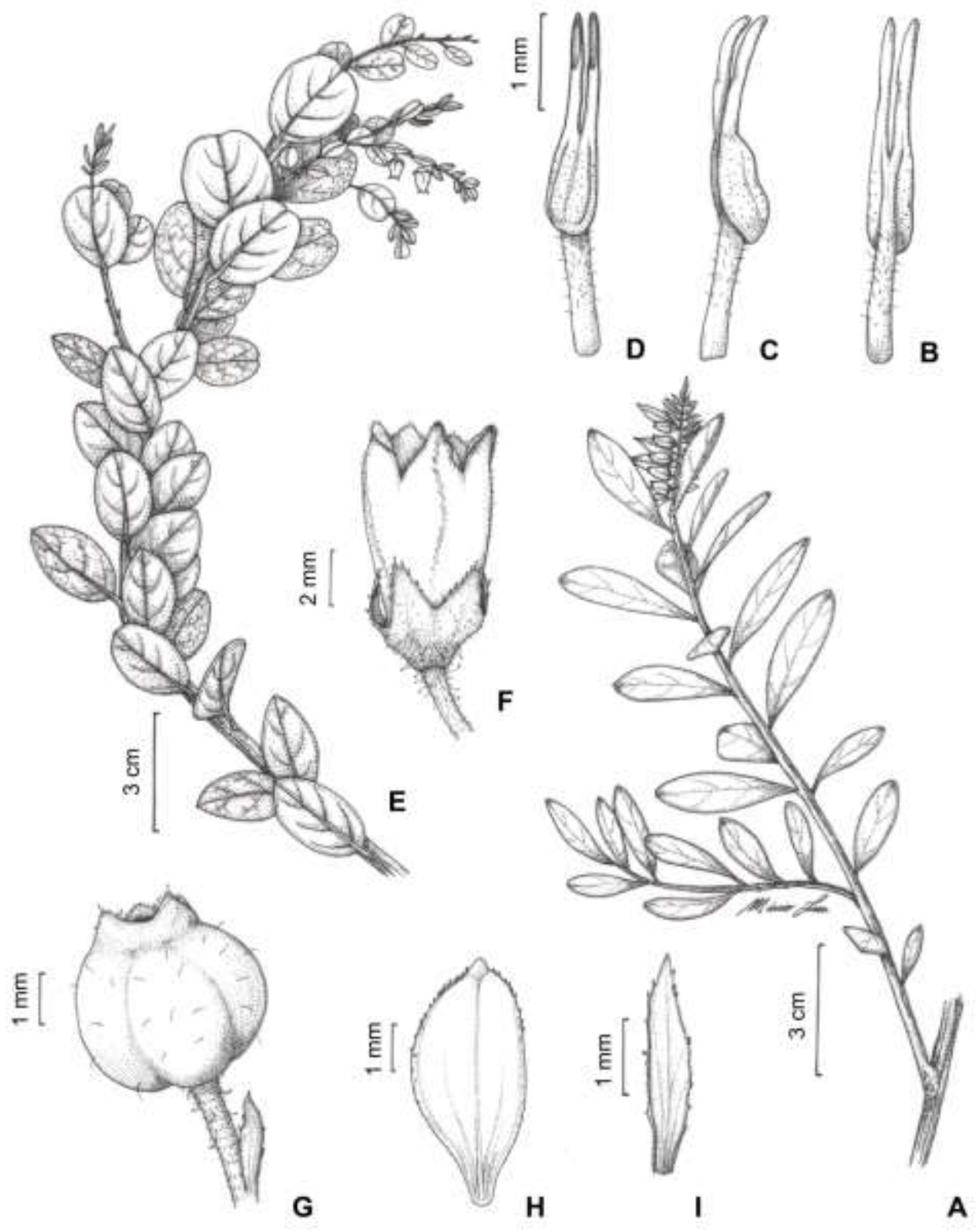

Fig. 3 - Gaylussacia. A-D. G. luizae (R.C. Forzza et al. 192): A. Ramo florido. B. Vista dorsal do estame. C. Vista lateral do estame. D. Vista frontal do estame. E-I. G. pseudociliosa (J. Semir CFS 5166): E. Ramo florido. F. Flor com corola campanulada. G. Fruto. H. Bráctea com glândula espessa no ápice. I. Bractéola. 
Gaylussacia martii está distribuída pela porção centro-sul da Cadeia do Espinhaço em Minas Gerais, especialmente na Serra do Cipó e arredores, aonde ocorre em campos rupestres, sobre solos arenopedregosos não alagáveis, próximo de blocos rochosos. Foi coletada com flores em fevereiro e de junho a setembro, com frutos em fevereiro, agosto e setembro.

Essa espécie é bastante semelhante a $G$. oleifolia e $G$. salicifolia, especialmente quanto ao aspecto das folhas. A principal diferença está no hábitat, já que G. martii ocorre em campos rupestres, sobre solos não alagáveis próximo de blocos rochosos, enquanto que $G$. oleifolia e G. salicifolia ocorrem em bordas ou interior de matas ciliares adjacentes a campos rupestres, sobre solos turfosos ou arenosos alagáveis até brejosos. Em complemento, G. martii apresenta folhas com 2,1-5,5 cm de comprimento, ramos glabros ou pubescentes, corola alva e com 5-8 mm de comprimento, G. oleifolia possui folhas $4-12,5 \mathrm{~cm}$, ramos glabros, corola alva, raro rosada ou arroxeada, de $5-10 \mathrm{~mm}$, enquanto que $G$. salicifolia tem folhas $(3,4) 4,5-8 \mathrm{~cm}$, ramos glabros e corola coccíneo-vermelha, de 9-11 mm. Ilustrações em Meisner (1863) e Romão (2011 inéd.).

2.7. Gaylussacia montana (Pohl) Sleum., Bot. Jarhb. Syst. 86: 344. 1967.

Subarbusto a arbusto, 0,2-0,8m alt., base procumbente. Tricomas simples patentes, alvos, nos ramos; tricomas glandulares fino-alongados, alvos, nos ramos; glândulas clavadas ou capitadopediceladas, nigrescentes nos ramos, folhas e flores. Ramos densamente pubescentes, esparsamente híspido-glandulares, mais densamente nos râmulos, às vezes glandulosos nos râmulos, densamente foliados, partes velhas desfoliadas. Folhas alternas, não imbricadas, (0,7-)1,2-3,4x0,4-2,7 cm, subcoriáceas, concolores, avermelhadas quando jovens; pecíolo 1-3(-4) mm compr., densamente pubescente, esparsamente híspido-glandular, às vezes glanduloso; limbo elíptico ou obovado a suborbicular, raramente ovalado, ápice arredondado a agudo, às vezes emarginado, mucronulado, com glândula apical espessa, achatada ou alongada, base aguda ou obtusa, raramente arredondada, margem inteira, plana ou ligeiramente revoluta, ambas as faces esparsamente pubescentes, mais densamente na nervura principal, esparsamente híspido-glandulares, glandulosas, nervação broquidódroma, nervuras proeminentes. Racemos axilares subapicais, 3-12floro; ráquis 1,3-4,2 cm compr., densamente pubescente, esparsamente híspido-glandular, glandulosa; bráctea foliácea, 4-6 mm compr., elíptica a obovada ou oblanceolada, densamente pubescente nas bordas e nervura, esparsamente híspidoglandular, glandulosa; bractéolas 3-4 mm compr., estreitamente elípticas a oblanceoladas ou lineares, inseridas na base até a porção mediana do pedicelo. Flores congestas; pedicelo 1-4 mm compr., densamente pubescente e híspido-glandular, glanduloso; hipanto pubescente e densamente híspido-glandular; cálice 2-4 mm compr., pubescente e híspido-glandular, glanduloso; corola urceolada a tubuloso-urceolada, menos comumente tubulosocampanulada, 4-7 $\mathrm{mm}$ compr., alva ou rosada, pubescente e híspido-glandular nos ângulos, lobos recurvados; estames $4,5-5 \mathrm{~mm}$ compr., filete pubescente, antera lisa; disco nectarífero glabro; estilete ca. $5 \mathrm{~mm}$ compr., glabro. Fruto 4-6 mm diâm., globoso, costado, avermelhado a vináceo ou negro, esparsamente pubescente e híspido-glandular.

Material examinado: Cardeal Mota, Serra do Cipó, caminho para Conceição do Mato Dentro, $19^{\circ} 20^{\prime} \mathrm{S} 43^{\circ} 35^{\prime} \mathrm{W}$, M.M. Arbo et al. 4648, 8.II.1991, fr. (ESA, SPF). Conceição do Mato Dentro, Serra do Cipó, Fazenda Palácio, Palacios et al. 3566b, 28.XII.1948, fr. (R). Jaboticatubas, Serra do Cipó, Rodovia Lagoa Santa-Conceição do Mato DentroDiamantina: Km 112, CFSC 655, M. Sakane, 25.X.1977, fl. (SP); Km 113, CFSC 5246, J. Semir et al., 28.X.1974, fl. (SP, UEC); Km 114, CFSC 3354, J. Semir \& M. Sazima, 4.IX.1972, fl. (SP); idem, CFSC 4455, A.B. Joly et al., 18.X.1973, fl. (SP); idem, CFSC 5206, 5207 e 5208, J. Semir et al., 8.IX.1974, fl. (SP, UEC); idem, CFSC 5229, 5230, 5232, 5233 e 5234, J. Semir et al., 27.X.1974, fl. (SP, UEC); idem, CFSC 5319, 5320, 5321, 5327 e 5328, J. Semir et al., 10.XII.1974, fl. (SP, UEC); idem, CFSC 5333, J. Semir et al., 11.XII.1974, fl.fr. (SP, UEC); idem, J. Semir 8679, 30.XI.1978, fl. (UEC); Km 115, CFSC 863, A.B. Joly et al., 4.III.1972, fr. (SP); idem, CFSC 5226, 5227 e 5228, J. Semir et al., 27.X.1974, fl.fr. (ESA, SP, UEC); idem, CFSC 5310, J. Semir et al., 30.X.1974, fl. (SP, UEC); Km 116, CFSC 191, A.B. Joly et al., 6.VI.1970, fl. (SP); Km 117, CFSC 5436, L.S. Kinoshita \& J. Semir, 15.XII.1974, fr. (SP); Km 120, CFSC 5303, J. Semir et al., 30.X.1974, fl.fr. (SP); Km 124, CFSC 5437, L.S. Kinoshita \& J. Semir, 15.XII.1974, fl.fr. (SP); Km 127, CFSC 4697, J. Semir \& M. Sazima, 29.X.1973, fl. (SP, UEC); idem, CFSC 5165 e 5167, J. Semir et al., 7.IX.1974, fl. (SP, UEC); idem, CFSC 5262 e 5264, J. Semir et al., 29.X.1974, fl.fr. (ESA, SP, UEC); idem, CFSC 5419, L.S. Kinoshita \& J. Semir, 13.XII.1974, fl. (SP); Km 128, CFSC 2469, A.B. Joly et al., 29.V.1972, fl. (SP); idem, $19^{\circ} 17^{\prime} \mathrm{S} 43^{\circ} 33^{\prime} \mathrm{W}, \mathrm{G}$. Eiten et al. 11031, 11.ll.1969, fr. (SP); estrada da Usina, CFSC 3464, A.B. Joly \& C. Müller, 9.IX.1972, fl. (SP); estrada da Usina, ao lado da ponte, CFSC 5107, J. Semir et al., 5.IX.1974, fl. (SP, UEC); estrada da Usina, CFSC 5416, L.S. Kinoshita \& J. Semir, 12.XII.1974, fl.fr. (SP). Santa Luzia, Serra do Cipó: Km 121, M. Barreto 5073, 30.X.1936, fl. (L, RB); Km 131, M. Barreto 5074, 30.X.1936, fl.fr. (BHCB, L, MBM, RB); idem, Palácio, M. Barreto 9252, 20.IX.1937, fl. (R). Santana do Riacho, Serra do Cipó, Rodovia Belo Horizonte-Conceição do Mato Dentro: $\mathrm{Km} 106,19^{\circ} 17^{\prime} \mathrm{S} 43^{\circ} 36^{\prime} \mathrm{W}$, G.M. Faria \& $M$. Mazucato 1990, X.1990, fl. (HRCB, SPF); idem, G.O. Romão et al. 1099, 4.XII.2004, fl. (BHCB, ESA, RB, SP, SPF, UEC); Km 111, CFSC 9752, R. Mello-Silva et al., 2.V.1986, fl.fr. (NY, SPF); $\mathrm{Km}$ 116,5, G.O. Romão 541, 546, 547 e 548, 2.XI.2000, fl. (ESA, SPF); idem, 19 16'15,3"S $43^{\circ} 32^{\prime} 51,5^{\prime \prime} \mathrm{W}$, G.O. Romão et al. 899, 10.I.2003, fr. (BHCB, ESA, RB, SP, SPF, UEC); idem, Alto do Palácio, G.O. Romão et al.1106, 5.XII.2004, fl.fr. (ESA, SP, UEC); Km 117, 19 16'16"S 433'ㄹ'W, G.O. Romão et al. 878, 879 e 880, 28.Il.2002, fr. (BHCB, ESA, RB, SP, SPF, UEC); idem, V.C. Souza et al. 28552 e 28566, 28.II.2000, fr. (BHCB, ESA, SPF); Km 120, M.G. Arrais et al. CFCR 5974, 14.XI.1984, fl. (ESA, SPF, UEC); Km 121, próximo à sede do antigo IBDF, 19 15'13,9"S 43 31'38,1"W, G.O. Romão et al. 866, 867 e 868, 28.II.2002, fr. (BHCB, ESA, RB, SP, SPF, UEC); idem, V.C. Souza et al. 
28637, 28.II. 2002, fr. (BHCB, ESA, SPF); Km 125, Alto do Palácio, CFSC 8512, N. Hensold 409, 7.XII.1981, fr. (ESA, SPF); idem, CFSC 9358, N.S. Chukr et al., 31.X.1985, fl. (ESA, MBM, SPF, UEC); idem, elevação em frente à estátua do Velho Juca, CFSC 12074, J.R. Pirani et al., 26.III.1991, fr. (ESA, SPF); Km 126, CFSC 9203, J.R. Pirani \& L. Rossi, 13.XI.1983, fl. (ESA, NY, SPF); Km 135, A.A.A. Barbosa s.n., 7.VI.1989, fl. (BHCB 21199, HUFU 2180); atalho para o Morro do Calcário, CFSC 7559, M.L. Kawasaki et al., 7.X.1981, fl. (ESA, SPF, UEC); cerca de $5 \mathrm{Km}$ após Chapéu do Sol, $19^{\circ} 17^{\prime} 11,7^{\prime \prime S} 43^{\circ} 35^{\prime} 20,6$ 'W, V.C. Souza et al. 8122, 10.III.1995, fr. (ESA, SPF, UEC); Fazenda Cachoeira da Capivara,

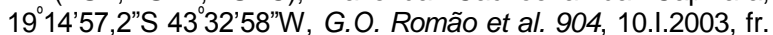
(BHCB, ESA, SPF); idem, G.O. Romão et al. 2442, 5.IV.2010, fr. (ESA, US); bifurcação para o Morro do Pilar, CFSC 10769, F.R. Salimena-Pires et al., 9.X.1987, fl. (SPF); Parque Nacional da Serra do Cipó, próximo à estátua do Juquinha, L.S. Kinoshita \& M.E. Mansanares 00/187a, 22.XI.2000, fl. (UEC); idem, G.O. Romão et al. 1113, 5.XII.2004, fl. (ESA); Pico do Breu, Lapinha, $19^{\circ} 07^{\prime} S 43^{\circ} 40^{\prime} W$, L.S. Kinoshita \& K. Matsumoto 00/604, 23.XI.2000, fl.fr. (ESA, UEC); idem, 19॰06'57"S 43॰40'17'W, K. Yamamoto et al. 59, 24.IX.2002, fl.

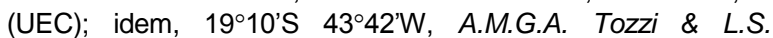
Kinoshita 568, 23.XI.2000, fl. (UEC); estrada entre Santana do Riacho-Lapinha, cerca de $8 \mathrm{Km}, 19^{\circ} 07^{\prime} 04,5^{\prime \prime} \mathrm{S} 43^{\circ} 41^{\prime} 56,2^{\prime \prime} \mathrm{W}$, V.C. Souza et al. 28729-A, 1.III.2002, fr. (BHCB, ESA, SPF); P.M. Andrade \& M.A. Lopes s.n., 15.IV.1985, fr. (BHCB 9099); G. Hatschbach \& C. Koczicki 35331, 25.X.1974, fl. (HB, MBM, UEC); M. Lucca et al. 56, 6.I.1993, fl. (BHCB); L. Queiroz \& A.G. Freire s.n., 1.V.1991, fl. (BHCB 20768). Serra do Cipó, estrada para Conceição do Mato Dentro: Km 120, H.S. Irwin et al. 20079-a, 14.Il.1968, fl. (NY, UB); idem, H.S. Irwin et al. $20144 a$ e 20170 , 15.II.1968, fl.fr.(NY, UB); Km 132, H.S. Irwin et al. 20337, 17.II.1968, fr. (NY, UB); Km 136-137, A.P. Duarte 2283, 7.XII.1949, fl. (RB); Km 140, A.P. Duarte 2405, 12.XIl.1949, fl. (RB, UEC); Palacinho, L. Travassos s.n., X.1959, fl.fr. (L 794699, RB 126895); W.R. Anderson et al. 36107, 17.II.1972, fl.fr. (NY, UB); W.R. Anderson et al. 36187 e 36196, 18.II.1972, fl.fr. (NY, RB, UB); E. Conta 347, 25.II.1984, fr. (RB); B. Costa 148, V.1933, fl. (R); J. Vidal s.n., VII.1949, fl. (R 136427).

Sleumer (1967) reconheceu três variedades com base no formato e dimensão das folhas. Na Serra do Cipó foi encontrada apenas G. montana var. montana, que se caracteriza por apresentar folhas elípticas ou obovadas a suborbiculares, de 0,4-2,7 cm de largura e corola pubescente e híspido-glandular nos ângulos.

Gaylussacia montana var. montana está restrita à Cadeia do Espinhaço em Minas Gerais e Bahia. Na Serra do Cipó ocorre em campos rupestres, sobre solos pedregosos não alagáveis ou entre rochas. Foi coletada com flores e frutos praticamente o ano todo.

Na Serra do Cipó, Gaylussacia montana juntamente a G. reticulata e $G$. riedelii são as espécies do gênero mais comumente encontradas. Ilustrações em Romão (2011 inéd.). 1839.

2.8. Gaylussacia oleifolia Dunal, Prodr. 7: 559.

Arbusto a arvoreta, raramente subarbusto, (0,5-)1-3,5(-5) m alt., esguio. Tricomas simples, alvos, nos filetes, raramente nas folhas e ráquis; tricomas glandulares ausentes; glândulas clavadas ou capitadosésseis, rubro-nigrescentes, nas folhas e flores. Ramos glabros, densamente foliados, ramos velhos desfoliados. Folhas alternas, não imbricadas, 4$12,2 \times 0,7-2,3 \mathrm{~cm}$, cartáceas ou raramente subcoriáceas, concolores; pecíolo 2-8 mm compr., glabro, raro pubérulo a pubescente; limbo estreitamente elíptico a oblongo ou obovado a oblanceolado, ápice obtuso a agudo, mucronulado, com glândula apical espesso-alongada, base aguda, margem serrilhada a serreada próximo do ápice, glandulosa entre os dentes, plana ou ligeiramente revoluta na base, ambas as faces glabras, raro esparsamente pubérulo a pubescente na base da nervura principal e margens na face superior, glandulosas, nervação broquidódroma, nervuras proeminentes, raramente impressas na face superior. Racemos axilares subapicais, pendentes, 8-29-floro; ráquis (3-)4,2-19,8 cm compr., glabra, raro pubérula a pubescente, glandulosa; bráctea foliácea, 5-14(-18) $\mathrm{mm}$ compr., rômbico-oblanceolada ou estreitamente elíptica a lanceolada, glabra, frequentemente com glândula apical espesso-alongada e glandulosa nas bordas; bractéolas 1-3 mm compr., linear-setiformes ou lanceoladas, inseridas da porção basal até a mediana do pedicelo. Flores laxas; pedicelo 8-19(-21) $\mathrm{mm}$ compr., avermelhado, glabro, raro pubescente, glanduloso; hipanto glabro, raramente glanduloso; cálice 1-2 mm compr., glabro, glanduloso nas bordas dos lobos, ápice desprovido de glândula calosa; corola tubuloso-urceolada, cilíndrica ou raramente campanulada, 5-10 $\mathrm{mm}$ compr., alva, raramente rosada ou arroxeada, glabra, lobos recurvados; estames 5,5-6,5 $\mathrm{mm}$ compr., filete densamente pubescente a tomentoso, antera granulada ou lisa; disco nectarífero glabro; estilete $5,5-8 \mathrm{~mm}$ compr., glabro. Fruto 3-8 mm diâm., depresso-globoso, costado, negro, glabro.

Material examinado: Conceição do Mato Dentro, Serra do Cipó, Km 141, M. Barreto 5072, 30.X.1936, st. (L). Congonhas do Norte: Serra Capão Grande, 1855’40,9"S 4341'32"W, F.N. Costa et al. 773, 24.IV.2004, fl. (DIAM, SPF); Serra do Cipó, Retiro do Barbado, $18^{\circ} 52^{\prime} S 43^{\circ} 46^{\prime} \mathrm{W}$, CFSC 8385, M.C.E. Amaral et al., 22.IV.1982, fr. (ESA, SPF); Serra do Cipó, Serra da Carapina-Serra Talhada, estrada para Santana do Riacho, $18^{\circ} 56^{\prime}$ S $43^{\circ} 41^{\prime} \mathrm{W}$, J.R. Pirani et al. 4185, 3.III.1998, fl. (SPF, UEC). Itambé do Mato Dentro, Serra do Cipó, Serra da Bandeirinha, 19²4'40"S 4329'40"W, N. Hensold CFCR 4224, 11.V.1982, fl.fr. (ESA, $\mathrm{MICH}$, SPF). Jaboticatubas, Serra do Cipó, Rodovia Lagoa Santa-Conceição do Mato Dentro-Diamantina: $\mathrm{Km} \mathrm{115}$, CFSC 4120, J. Semir et al., 29.IV.1973, fl. (SP); Km 117, CFSC 5277, J. Semir et al., 29.X.1974, fr. (SP, UEC); Km 120, CFSC 4418, J. Semir et al., 5.IX.1973, fl.fr. (SP); Km 124, M. Magalhães s.n., 12.VIII.1936, fl. (BHMH 17562, ICN 15988b); Km 127, CFSC 4704, J. Semir \& M. Sazima, 29.X.1973, fr. (ESA, SP, UEC); idem, CFSC 5170 e 5171, J. Semir et al., 7.IX.1974, fl.fr. (ESA, SP, UEC); idem, CFSC 5263 e 5266, J. Semir et al., 29.X.1974, fr. (SP, UEC); idem, CFSC 5418, L.S. Kinoshita \& J. Semir, 13.XII.1974, fr. (SP UEC); idem, CFSC 5448, L.S. Kinoshita et al., 29.IV.1975, fr. (SP); Km 131, M. Magalhães s.n., 18.VIII.1940, fl.fr. (BHMH 33873, ICN 15988c); idem, J.E. Oliveira 144, 18.VIII.1940, fr. 
(BHCB, ESA, MBM, SPF); Km 132, CFSC 2019a, J. Semir \& M. Sazima, 30.IV.1972, fl. (ESA, UEC); idem, CFSC 3149 , A.B Joly \& J. Semir, 21.VIII.1972, fl. (ESA, UEC); idem, CFSC 3869, M. Sazima \& J. Semir, 16.II.1973, fl.fr. (SP); idem, CFSC 5248, J. Semir et al., 28.X.1974, fr. (SP); idem, CFSC 5433, L.S. Kinoshita \& J. Semir, 14.XII.1974, fr. (SP, UEC); $\mathrm{Km}$ 134, M. Magalhães s.n., s.d, fl. (BHMH 17326, ICN 15988d); Km 138, CFSC 5139-B, J. Semir et al., 6.IX.1974, fl.fr. (SP); Km 141, M. Magalhães s.n., 30.X.1936, fl. (BHMH 17991, ICN 15988a); nas proximidades do Parque, rumo a Conceição do Mato Dentro, H.F. Leitão-Filho et al. 27358, 7.XII.1992, fl.fr. (ESA, UEC); Palácio, 19॰10’S $43^{\circ} 35^{\prime} \mathrm{W}$, L.B. Smith et al. 6778, 28.IV.1952, fl. (R); Serra do Cipó, G. Hatschbach 29980, 6.VIII.1972, fl.fr. (HB, MBM, UPCB, UEC) Santa Luzia, Serra do Cipó: Km 124, M. Barreto 4410, 12.VIII.1936, fl. (BHCB, RB); Km 127, Palácio, M. Barreto 6876, 3.IX.1933, fl. (BHCB, MBM);Km 134, M. Barreto \& A.C. Brade 1104, 15.IV.1935, fl. (BHCB, MBM, R, RB, UEC); estrada para o Pilar, Km 138, M. Barreto 1100, 15.IV.1935, fl. (BHCB, RB); Fazenda Palácio, M. Barreto 515, 6.VIII.1933, fl. (BHCB, R). Santana do Pirapama, Serra do Cipó, Serra

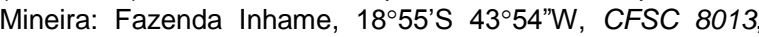
J.R. Pirani et al., 21.III.1982, fl. (ESA, SPF, UEC); idem, $18^{\circ} 55^{\prime}$ 'S 4354"W, CFSC 8064, J.R. Pirani et al., 22.III.1982, fl. (ESA, K, SPF, UEC). Santana do Riacho, Serra do Cipó, Rodovia Belo Horizonte-Conceição do Mato Dentro: Km 110, CFSC 11532, A. Bidá, 21.V.1986, fl. (SPF); Km 116, $19^{\circ} 16^{\prime} 01,3^{\prime \prime S} 43^{\circ} 33^{\prime} 04,1^{\prime \prime W}$, G.O. Romão 890, 911 e 912, 10.I.2003, fl.fr. (BHCB, ESA, RB, SP, SPF, UEC); Km 123 , CFSC 8573, J.D. Pinheiro \& G.L. Esteves, 31.VI.1982, fl. (ESA, SPF); Km 120, próximo à estátua do Juquinha, M.A. Farinnaccio et al. 53a, 7.VI.1997, fl.fr. (HRCB); Km 117, 19'16'16"S 4332'52"W, G.O. Romão et al. 877, 28.II.2002, fl. (BHCB, ESA, SPF, UEC); idem, 19॰16'16"S 4332'52"W, V.C. Souza et al. 28562, 28.Il.2002, fl. (ESA, HPL, SP); Km 127, CFSC 5084, J. Semir \& M. Sazima, 7.VII.1977, fl. (ESA, SP, SPF); idem, Alto Palácio, Fazenda Capivara, R. Marquete et al. 29, 25.V.1987, fl. (HRB, RB); Km 131, CFSC 6057, I. Cordeiro et al., 30.III.1980, fl. (SP, SPF); Km 132, CFSC 3868, M. Sazima \& J. Semir, 16.II.1973, fl. (ESA, SP, SPF); $\mathrm{Km} 134$, CFSC 7525, I. Cordeiro et al., 6.X.1981, fl.fr. (ESA, SPF, UEC); Km 135, próximo ao Palácio, H.C. Lima 389 , 25.IV.1978, fr. (NCU, RB); Alto do Palácio sede do IBAMA, J.R. Pirani et al. 5068, 8.VI.2002, fl.fr. (ESA, SPF); estrada para Lagoa Santa, a $17 \mathrm{Km}$, C. Farney et al. 442, 25.II.1984, fl. fr. (RB); Alto do Palácio, CFSC 9888, T.B. Cavalcanti et al., 12.IX.1986, fl.fr. (ESA, K, SPF); próximo à estátua do Juquinha, G.O. Romão et al. 901 e 922, 10.I.2003, fr. (BHCB, ESA, SPF); idem, $19^{\circ} 15^{\prime} 30^{\prime \prime} S 43^{\circ} 34^{\prime} 04^{\prime \prime W}$, G.O. Romão et al. 735, 5.VII.2001, fl.fr. (ESA); idem, 19॰15'30”S 4334'04”W, V.C. Souza et al. 25203, 5.VII.2001, fl.fr. (BHCB, ESA, SPF); próximo à bifurcação para o Morro do Pilar, 19॰13'13"S 4329'57'W, G.O. Romão et al. 736, 5.VII.2001, fl. (ESA):

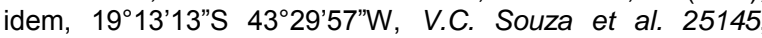
28.II.2002, fl. (BHCB, ESA, SPF); Parque Nacional da Serra do Cipó, sede do IBAMA do Alto do Palácio, $19^{\circ} 08^{\prime} S$ 434'W, M. Groppo Jr. et al. 1073, 9.VI.2002, fl.fr. (ESA, SPF); idem, CFSC 12264, J.R. Pirani et al., 27.IV.1991, fl. (ESA, SPF); idem, próximo à estátua do Velho das Flores, CFSC 11504, F.R. Salimena-Pires et al., 20.V.1989, fl. (ESA,

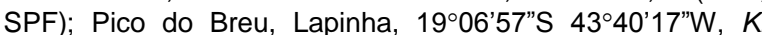
Yamamoto et al. 58, 24.IX.2002, fr. (ESA, UEC); RPPN Brumas do Espinhaço, M.G.C. Fernandes et al. 1401, 9.VII.2012, fl. (BHZB, UEC); Serra do Cipó, Chapéu de Sol, I.S.M. Gajardo et al. s.n., 4.Il.1998, fl. (ESA 76731, HRCB); Serra da Salitreira, próximo à sede do Parque Nacional da Serra do Cipó, córrego Água Preta, CFSC 10401, C. Kameyama et al., 12.VII.1987, fl. (ESA, SPF); N.M. Castro s.n., 7.VI.1989, fl. (BHCB 21201, HUFU 2268). Serra do Cipó: estrada para Conceição do Mato Dentro, Km 120, H.S. Irwin et al. 20079b, 14.Il.1968, fl. (K, NY, SP); idem, H.S. Irwin et al. 20144b, 15.II.1968, fl. (HB, K, NY); Km 134, A.C. Brade \& Mello-Barreto 14893, 15.IV.1935, fl. (RB, UEC); Km 138, A.P. Duarte 9146, 16.IV.1965, fl. (F, HB, RB); Km 140, M. Barreto 1099 e 7094, 15.IV.1935, fl. (RB); Juquinha, D.M. Braz et al. 65, 7.II.2001, fl.fr. (HRCB); idem, I.S.M. Gajardo et al. 64 e 66, 4.II.1998, fl. (HRCB, UEC); Schwacke 8283, 24.IV.1892, fl. (RB); Serra da Salitreira, próximo à casa do IBDF, I.R. Andrade \& M.B. Horta 77, 12.VII.1987, fl.fr. (SPF); W.R. Anderson et al. 36181b, 18.Il.1972, fl.fr. , (NY, UB); $L$. Damazio 2031, 1908, fl.fr. (G); R. Parentoni 8250, 15.VII.1978, fl. (UEC); G. Pedralli s.n., 3.IV.1992, fl. (HXBH 10573); H.E. Strang 1389, 1.Il.1970, fl. (GUA).

Gaylussacia oleifolia está restrita à porção centro-sul da Cadeia do Espinhaço em Minas Gerais, especialmente na Serra do Cipó, aonde ocorre no interior ou bordas de matas ciliares adjacentes a campos rupestres, sobre solos turfoso-arenosos ou brejosos. Foi coletada com flores ou frutos praticamente o ano todo, exceto em novembro.

Essa espécie é distinta das demais por apresentar folhas comparativamente longas (4-12,2 $\mathrm{cm}$ ), estreitamente elípticas a oblongas ou obovadas a oblanceoladas, ramos e folhas glabras em geral, além de corola comumente alva (raramente rosada ou arroxeada, observada apenas nos espécimes CFSC 2019a, 3149, 3869 e 5248) e flores longamente pediceladas, 8-19(-21) $\mathrm{mm}$. Além disso, relaciona-se com G. martii e G. salicifolia, discutido anteriormente. llustrações em Meisner (1863) e Romão (2011 inéd.).

2.9. Gaylussacia pinifolia Cham. \& Schltdl., Linnaea 1: 536. 1826.

Fig. 2. I.

Subarbusto a arbusto, 0,3-0,75 m alt., procumbente. Tricomas simples, alvos, geralmente nas brácteas e cálice; tricomas glandulares ausentes; glândulas clavadas ou cônicas, nigrescentes na margem das folhas, brácteas, ráquis e pedicelo, rubras no cálice. Ramos glabros, densamente foliados, ramos velhos desfoliados. Folhas alternas a subopostas, congestas, não imbricadas, 0,7-4,1($5,2) \times 0,1-0,2 \mathrm{~cm}$, subcoriáceas, discolores, espessas; pecíolo 1-2(-3) mm compr., glabro; limbo linearaciculado, ápice agudo, mucronulado, com glândula apical espesso-cônica, base aguda a atenuada, margem serrilhada a subcrenulada da base até o ápice, glandulosa entre os dentes, plana, ambas as faces glabras e desprovidas de glândulas, nervação hifódroma, impressa na face superior, proeminente na inferior. Racemos axilares ou terminais, 5-8-floro; ráquis $0,6-2,3 \mathrm{~cm}$, glabra, glandulosa; bráctea $2-4 \mathrm{~mm}$ compr., oval-lanceolada ou rômbica, glabra ou pubescente, frequentemente glandulosa nas bordas; bractéolas 1-2 $\mathrm{mm}$ compr., linear-lanceoladas, inseridas na base ou ápice do pedicelo. Flores congestas; pedicelo 2-4 mm compr., glabro, glanduloso; hipanto glabro, desprovido de glândulas; cálice 1-2 mm compr., glabro ou ciliado, 
frequentemente glanduloso nas bordas dos lobos; corola tubuloso-urceolada, raramente campanulada, 3$5 \mathrm{~mm}$ compr., alva ou rosada, glabra, lobos ligeiramente recurvados; estames 3-4 mm compr., filete esparsamente pubescente, antera granulada; disco nectarífero glabro; estilete 3-3,5 mm compr., glabro. Fruto 2-3 mm diâm., depresso-globoso, vináceo, costado, glabro.

Material examinado: Jaboticatubas: Serra do Charco, M. Magalhães 2340, 23.XI.1940, st. (ICN); Serra do Cipó, Km 134, s.col., 15.IV.1935, fl.fr. (BHMH 17328, ICN 15984a). Lagoa Santa, Serra do Cipó, L. Damazio \& L. Oliveira s.n., VI.1908, fl. (OUPR 5997). Santa Luzia, Serra do Cipó, estrada para Morro do Pilar, Km 138, M. Barreto 8967, 4.Il.1938, fl. (R). Santana do Riacho, Serra do Cipó, Rodovia Belo Horizonte-Conceição do Mato Dentro: Km 109, F. Barros 1305, 1.Il.1987, fl. (ESA, SP, SPF); Km 132, H.S. Irwin et al. 20253, 16.Il.1968, fl.fr. (MO, NY, RB, UB); Km 134, M. Barreto \& A.C. Brade 1105 e 14892b, 15.IV.1935, fl.fr. (ESA, L, RB, UEC); Fazenda Cachoeira da Capivara, 1945'59,9'S 4332'44,2”W, V.C. Souza et al. 8213, 10.III.1995, fl. (ESA, NY, SPF, US); Parque Nacional da Serra do Cipó, Serra da Bandeirinha, caminho para Cachoeira das Flores, CFSC 10646 e 10647b, M.G.L. Wanderley et al., 9.IX.1987, fl. (ESA, SP, SPF); idem, CFSC 12599, A.M. Giulietti et al., 28.VII.1991, fl.fr. (ESA, MBM, MO, SPF); Serra do Cipó, $19^{\circ} 20^{\prime}$ S $43^{\circ} 35^{\prime}$ W, M.M. Arbo et al. 4656, 8.Il.1991, fl. (ESA, SPF). Serra do Cipó: Km 104, M. Barreto \& A.C. Brade 14892a, 15.IV.1935, fl. (ESA, RB); Km 134, A.C. Brade 14892, 15.IV.1935, fl.fr. (RB, UEC); M. Brandão 10486, s.d., fl. (PAMG); C.Sena 11771, VIII.1895, fr. (L).

Gaylussacia pinifolia está restrita à porção centro-sul da Cadeia do Espinhaço em Minas Gerais, especialmente em topos de morros na Serra do Cipó, Serra do Caraça e região de Ouro Preto. Na Serra do Cipó ocorre em campos rupestres adjacentes às matas ciliares, sobre solos arenosos não alagáveis ou entre blocos rochosos. Foi coletada com flores de fevereiro a junho, setembro e dezembro, com frutos em fevereiro, abril, agosto e dezembro.

Essa espécie é facilmente distinta das demais por possuir folhas linear-aciculadas, 1-2 mm de largura, muito aproximadas mas não imbricadas e espessas mas não carnosas, com margem serrilhada a subcrenulada da base até o ápice. Ilustrações em Romão (2011 inéd.).

2.10. Gaylussacia pseudociliosa Sleum., Bot. Jahrb. Syst. 86: 348. 1967.

Fig. 3. E-I.

Subarbusto, 0,3-0,6 m alt., procumbente. Tricomas simples, alvos ou cremes, nos ramos, folhas, flores e frutos; tricomas glandulares robustoalongados, cremes, nas folhas e flores; glândulas clavadas ou capitado-sésseis, nigrescentes, nas folhas e flores. Ramos glabros a densamente pubescentes, densamente foliados, ramos velhos desfoliados. Folhas alternas, não imbricadas, (1-)1,5-3,5x0,5-2,3 $\mathrm{cm}$, subcoriáceas a rigidamente coriáceas, espessas, concolores; pecíolo 1-3 mm compr., esparsamente pubescente e hispídulo-glandular; limbo ovalado ou elíptico, raramente oblongo, ápice arredondado ou obtuso, mucronulado, com glândula apical espessoachatada ou depresso-subumbilicada, base arredondada ou obtusa, raramente aguda, margem subcrenulada ou serrilhada próximo ao ápice, glandulosa entre os dentes, plana ou ligeiramente revoluta próximo à base, raramente ciliado-glandular, face superior não bulada, ambas as faces glabras ou esparsamente pubescentes, hispídulo-glandulares na nervura central da face inferior nas folhas jovens, geralmente glandulosas, nervação broquidódroma, nervuras ligeiramente proeminentes. Racemos axilares subapicais, 5-12-floro; ráquis 1,7-6,3 cm compr., pubescente, raramente hispídulo-glandular, glandulosa; bráctea foliácea, 4-8mm compr., elíptica a ovalada ou rômbica a obtrulada, pubescente, às vezes hispídulo-glandular na região apical e bordas, glandulosa, ápice com glândula espessa; bractéolas 2 $4 \mathrm{~mm}$ compr., lanceoladas ou estreitamente elípticas, inseridas da porção basal até a apical do pedicelo. Flores congestas; pedicelo 2-8 $\mathrm{mm}$ compr., pubescente e hispídulo-glandular, glanduloso; hipanto densamente pubescente, às vezes hispíduloglandular, glanduloso; cálice 1-2 mm compr., esparsamente pubescente, hispídulo-glandular na base e bordas dos lobos, glanduloso; corola urceolada, tubuloso-urceolada, campanulada ou cilíndrica, 5-7 mm compr., alva ou rosada, esparsamente pubescente nos ângulos, lobos retos ou recurvados; estames 5-6,5 $\mathrm{mm}$ compr., filete pubescente a tomentoso, antera lisa ou granulada; disco nectarífero glabro; estilete 5,5-8 mm compr., glabro. Fruto 2-5 mm diâm., ovóide ou globoso, costado, avermelhado, pubescente e hispíduloglandular.

Material examinado: Conceição do Mato Dentro, Serra do Cipó: Palacios et al. 3566a, 28.XII.1948, fr. (L, LIL); Palacios et al. 3607, 22.XII.1948, fr. (L, LIL). Jaboticatubas, Serra do Cipó, Rodovia Lagoa Santa-Conceição do Mato Dentro-Diamantina: Km 114, CFSC 5204, J. Semir et al., 8.IX.1974, fl. (SP); idem, J. Semir 8678, 30.XI.1978, fl. (UEC); Km 115, CFSC 610b, J. Semir \& M. Sazima, 15.XII.1971, fl.fr. (SP); Km 127, CFSC 4702, J. Semir \& M. Sazima, 29.X.1973, fl. (ESA, SP); idem, CFSC 5166, J. Semir et al., 7.IX.1974, fl.fr. (SP); idem, CFSC 5265, J. Semir et al., 29.X.1974, fr. (SP); idem, CFSC 5441, L.S. Kinoshita et al., 29.IV.1975, fl. (ESA, UEC); Km 128, CFSC 299b, A.B. Joly et al., 7.VI.1970, fl.fr. (SP). Santana do Riacho, Serra do Cipó, rodovia MG-10 Santana do Riacho-Conceição do Mato Dentro: Km 105, M.S.F. Silvestre 185, 3.XI.1978, fl. (ESA, SP); Km 116,5, Alto do Palácio, G.O. Romão et al. 1102, 5.XII.2004, fl.fr. (ESA); próximo à estátua do Juquinha, 19॰15'30"S 43॰34’04”W, G.O. Romão et al. 732-B, 5.VII.2001, fl.fr. (ESA); RPPN Brumas do Espinhaço, M.G.C. Fernandes et al. 1517, 10.VII.2012, fl. (BHZB, UEC).Serra do Cipó, Km 131, A.P. Duarte 1977, 13.III.1949, fl. (L, LIL, RB); idem, A.P. Duarte 2977, 3.XII.1949, fl. (RB).

Gaylussacia pseudociliosa está restrita à região da Serra do Cipó e Planalto Diamantina, na Cadeia do Espinhaço em Minas Gerais. Na Serra do Cipó ocorre em campos rupestres, sobre solos pedregosos ou 
arenosos comumente alagáveis, às vezes próximo a curso d'água. Foi coletada com flores de março a dezembro, exceto em maio, com frutos de junho a dezembro, exceto em novembro.

Essa espécie caracteriza-se por apresentar folhas em geral rigidamente coriáceas e espessas, além de cálice hispídulo-glandular na base e bordas dos lobos, com tricomas glandulares robustoalongados.

No aspecto geral da planta, essa espécie assemelha-se bastante a $G$. ciliosa e G. riedelii, discutido anteriormente. Os espécimes CFSC 4702 , 5166, 5204, 5265, Romão 732-B e Silvestre 185 foram primeiramente tratados como $G$. aff. vitis-idaea em Romão (2011 inéd.), mas estes podem ser uma forma de G. pseudociliosa com folhas subcoriáceas a coriáceas e corola cilíndrica a campanulada, embora haja a necessidade de mais estudos. Ilustrações em Romão (2011 inéd.).

2.11. Gaylussacia pulchra Pohl, PI. Bras. 2: 41. t.127. 1831.

Subarbusto a arbusto, 0,3-2 $\mathrm{m}$ alt., ereto. Tricomas simples, alvos, nos ramos, folhas e flores; tricomas glandulares robusto-curtos, rubros, no cálice, hipanto e ráquis da inflorescência; glândulas clavadas, rubras a nigrescentes, nos râmulos e folhas. Ramos densamente pubescentes a tomentosos, glandulosos, densamente foliados. Folhas alternas, não imbricadas, 2,4-4,5x0,8-1,5 cm, coriáceas, discolores; pecíolo 2-4 mm compr., densamente tomentoso e glanduloso; limbo obovado a oblanceolado, ápice obtuso a arredondado, mucronulado, com glândula apical depresso-capitada, base aguda, margem serrilhada próximo ao ápice, glandulosa entre os dentes, revoluta, face superior bulada, ambas as faces pubescentes a tomentosas, mais densamente na face inferior, glandulosas, nervação broquidódroma, nervuras impressas na face superior, proeminentes na inferior. Racemos axilares subapicais, 5-9-floro; ráquis 0,9-2,8 cm compr., densamente pubescente a tomentosa e esparsamente hispídulo-glandular; bráctea 3-6mm compr., obtrulada, ciliada, glandulosa nas bordas; bractéolas 2-3 mm compr., linearsetiformes, inseridas na porção mediana até apical do pedicelo. Flores congestas; pedicelo 3-6 mm compr., densamente pubescente a tomentoso e hispíduloglandular; hipanto hispídulo-glandular na base; cálice ca. $2 \mathrm{~mm}$ compr., pubescente e hispídulo-glandular nas bordas dos lobos; corola urceolada ou tubulosourceolada, 6-8 mm compr., vermelha, glabra, lobos recurvados; estames 4-5 $\mathrm{mm}$ compr., filete densamente pubescente, antera granulada; disco nectarífero glabro; estilete 4-5 $\mathrm{mm}$ compr., glabro. Fruto 4-5 mm diâm., subgloboso, costado, vináceo, glabro.

Material examinado: Congonhas do Norte, Serra Talhada (setor nordeste da Serra do Cipó): estrada para o

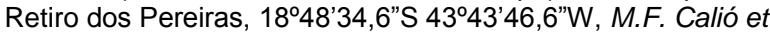

al. 177, 19.I.2007, fl. (SPF); idem, vale do Rio Preto, 1850'26"S 4344'53"W, J. Lovo et al. 28, 19.I.2004, fl. fr. (SPF); idem, ponte sobre o rio Preto, $18^{\circ} 47^{\prime} 57^{\prime \prime} \mathrm{S} 43^{\circ} 42^{\prime} 35^{\prime \prime} \mathrm{W}$, J.R. Pirani et al. 5778-A, 4.II.2009, fl. fr. (ESA, SPF).

Gaylussacia pulchra está distribuída no domínio Cerrado adentrando pela Caatinga, ao longo da Cadeia do Espinhaço em Minas Gerais e Bahia, eventualmente na Serra do Ibitipoca e nos estados do Espírito Santo e Pernambuco. Na Serra do Cipó ocorre em bordas de matas ciliares, sobre solos arenosos ou pedregosos não alagáveis. Foi coletada com flores e frutos em janeiro e fevereiro.

Essa espécie distingue-se das demais por apresentar folhas com a face superior bulada, geralmente revoluta e tricomas glandulares no cálice e hipanto. Pela semelhança no aspecto geral e na corola urceolada vermelha, é facilmente confundida com Gaylussacia brasiliensis (Spreng.) Meisn. var. brasiliensis, a qual é a espécie mais comum e amplamente distribuída pelo território brasileiro, mas que não apresenta tricomas glandulares. Ilustrações em Pohl (1831) e Romão et al. (2004).

2.12. Gaylussacia reticulata Mart. ex Meisn. in Mart., FI. bras. 7: 142, t.55. 1863.

Fig. 2. B.

Subarbusto a arbusto, 0,15-1 m alt., ereto. Tricomas simples, alvos ou cremes, nos ramos, folhas, flores e frutos; tricomas glandulares finoalongados, alvos, em indivíduos jovens nas flores e frutos, às vezes nas folhas, geralmente ausentes em toda planta; glândulas clavadas ou capitadas sésseis, nigrescentes, nos ramos e folhas. Ramos densamente pubescentes a tomentosos, glandulosos, subdensamente foliados, partes velhas desfoliadas. Folhas alternas, não imbricadas, 0,9-2,7x0,2-1,2(-1,5) $\mathrm{cm}$, coriáceas, concolores; pecíolo 1-3 mm compr., densamente pubescente a tomentoso; limbo obovado a oblanceolado ou elíptico a oblongo, raramente suborbicular, ápice arredondado ou agudo, mucronulado, com glândula apical espessa, umbilicada, base aguda a arredondada, margem inteira, fortemente revoluta, às vezes quase totalmente enrolada, ambas as faces esparsa a densamente pubescentes a tomentosas, às vezes híspidoglandulares na nervura central em brotações basais de indivíduos jovens, glandulosas na face inferior, nervação reticulódroma, nervuras impressas na face superior, marcadamente elevado-proeminentes na inferior. Racemos axilares subapicais, 3-20-floro; ráquis $(0,8-) 1,1-4,4 \quad \mathrm{~cm}$ compr., densamente pubescente, às vezes esparsamente tomentosoglandular, glandulosa; bráctea 3-5 mm compr., rômbica a oblanceolada, densamente pubescente a tomentosa, glandulosa nas bordas; bractéolas 1-3 mm compr., linear-setiformes, inseridas na base ou no ápice do pedicelo. Flores congestas; pedicelo 1-4 mm compr., densamente pubescente, às vezes tomentosoglandular, glanduloso; hipanto densamente tomentoso, 
menos comumente tomentoso-glandular, glanduloso; cálice 2-3 mm compr., geralmente glabro; corola urceolada, tubuloso-urceolada, cilíndrica ou campanulada, 4-6 mm compr., alva a rosada, esparsamente pubescente a tomentosa, mais densamente nos ângulos, lobos retos ou recurvados; estames 3-4 mm compr., filete densamente pubescente nas bordas, glanduloso, antera lisa; disco nectarífero densamente pubescente a tomentoso; estilete ca. $5 \mathrm{~mm}$ compr., glabro. Fruto 3-5 mm diâm., globoso ou elipsóide, costado, negro, densamente pubescente, menos comumente tomentoso-glandular, glanduloso.

Material examinado: Conceição do Mato Dentro: Pito Aceso, G. Hatschbach et al. 52914, 19.V.1989, fl.fr. (MBM). Congonhas do Norte, Serra do Cipó: estrada Congonhas do

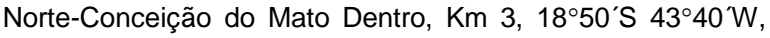
CFSC 8303, A. Furlan et al., 20.IV.1982, fl. (ESA, SPF); Serra Talhada, P. Fiaschi \& F.N. Costa 304, 17.VI.2000, fl. (SPF). Jaboticatubas, Serra do Cipó, Rodovia Lagoa SantaConceição do Mato Dentro-Diamantina: Km 126, CFSC 3320 , J. Semir \& M. Sazima, 3.IX.1972, fl. (SP); Km 127, CFSC 5172 e 5173, J. Semir et al., 7.IX.1974, fl.fr. (SP, UEC); Km 132, CFSC 2369, J. Semir et al., 28.V.1972, fl.fr. (ESA, SP, UEC); idem, CFSC 3153, A.B. Joly \& J. Semir, 21.VIII.1972, fl. (SP, UEC); idem, CFSC 3487, N.L. Menezes, 10.IX.1972, fl. (SP, UEC); idem, CFSC 3923, M. Sazima \& J. Semir, 16.II.1973, fl.fr. (SP); idem, CFSC 5147 e 5148, J. Semir et al., 6.IX.1974, fl. (SP); idem, CFSC 5249 e 5250, J. Semir et al., 28.X.1974, fl.fr. (SP, UEC); idem, CFSC 5334 e 5335, J. Semir et al., 11.XII.1974, fl.fr. (SP, UEC); idem, CFSC 5435, L.S. Kinoshita \& J. Semir, 14.XI.1974, fl.fr. (SP); idem, J. Semir et al. 5336, 11.XIl.1974, fl. (UEC); Km 132,5, CFSC 3487, N.L. Menezes, 10.IX.1972, fl. (SP, UEC); a $6 \mathrm{~km}$ ao norte de Palácio, F. Segadas-Vianna \& J. Loredo Jr. 1083, X.1953, fl. (R). Santa Luzia, Serra do Cipó, estrada para o Pilar, M. Barreto 467, 24.VIII.1933, fl. (BHCB, RB). Santana do Pirapama, Serra do Cipó: Fazenda Inhame, 1855'47,6”S 4347'2,7'W, G.O. Romão et al. 2396, 27.XI.2009, fl.fr. (BHCB, ESA, K, MBM, RB, SPF, UEC); distrito de São José da Cachoeira, trilha da captação da fazenda Toucan, 190'22"S 4345'20"W, V.C. Souza et al. 32539, 17.II.2007, fl.fr. (BHCB, CTES, ESA, MBM, PORT, SP, SPF, UB, UEC);

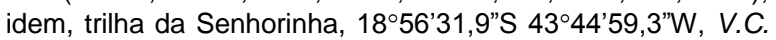
Souza et al. 32858 e 32862, 19.II.2007, fl.fr. (BHCB, ESA, K, RB, SPF); idem, G.O. Romão et al. 2365, 19.Il.2007, fl.fr. (ESA, SPF, UEC); idem, trilha para o Cruzeiro, $19^{\circ} 00^{\prime} 58,7^{\prime \prime} \mathrm{S}$ 4344'57,8"W, G.O. Romão et al. 1961, 1963, 1965, 1967 e 1968, 21.II.2007, fr. (ESA, G, K, L, M, NY, UEC). Santana do Riacho, Serra do Cipó, Rodovia Belo Horizonte-Conceição do Mato Dentro: Km 107, caminho para a Usina, CFSC 8943, E. Forero et al. 8030, 7.IX.1980, fl. (SP, SPF); Km 116,5, G.O. Romão 540, 542 e 549, 2.XI.2000, fl. (ESA, SPF); idem, 19'16'15,3"S 43'32'51,5”W, G.O. Romão et al. 900, 920 e 921, 10.I.2003, fl.fr. (BHCB, ESA, SPF); idem, Alto do Palácio, G.O. Romão et al. 1107, 5.XII.2004, fl.fr. (ESA, SP, UEC); Km 119, Fazenda Cachoeira da Capivara, $19^{\circ} 14^{\prime} 58,1^{\prime \prime S} 43^{\circ} 32^{\prime} 41^{\prime \prime W}$, G.O. Romão et al. 871, 28.II.2002, fr. (BHCB, ESA, RB, SP, SPF, UEC); idem, Fazenda Cachoeira da Capivara, $19^{\circ} 14^{\prime} 58^{\prime \prime}{ }^{\prime} 43^{\circ} 32^{\prime} 41^{\prime \prime W}$, G. O. Romão \&A.P.T. Dantas 2264, 8.IX.2007, fl. (ESA, L); idem, V.C. Souza et al. 28620, 28.II.2002, fr. (BHCB, ESA, SPF); $\mathrm{Km}$ 120-121, CFSC 8811e8829, E. Forero et al. 7898e 7916,
6.IX.1980, fl. (SP, SPF); Km 125, 19॰14'40"S 4332'40”W, CFSC 8511, N. Hensold 408, 7.XII.1981, fr. (ESA, K, SPF); idem, CFSC 9357, A.M. Giulietti et al., 31.X.1985, fl. (ESA HUEFS, K, SPF, UEC); idem, em frente à estátua do Velho Juca, CFSC 12072, J.R. Pirani et al., 26.III.1991, fl. (ESA, SPF); Km 127, CFSC 4719, J. Semir \& M. Sazima, 29.X.1973, fr. (ESA, SP); Km 135, próximo do Palácio, H.C. Lima 368, 24.IV.1978, fl. (NY, RB); Km 138, Alto do Palácio, B. Stannard et al. CFCR 6053, 15.XI.1984, fl.fr. (ESA, SPF); Alto do Palácio, CFSC 9889, T.B. Cavalcanti et al., 12.IX.1986, fl.fr. (ESA, SPF); idem, arredores da sede do IBAMA, V.C. Souza \& C.M. Sakuragui 3328, 1.V.1993, fl. (ESA, UEC); estrada entre a Fazenda Palácio e a estátua do Juca, L.S. Kinoshita \& K. Matsumoto 00/543, 22.XI.2000, fr. (ESA, UEC); Fazenda Cachoeira da Capivara, 19॰14'57,2"S 4332'58”W, G.O. Romão et al. 907, 10.I.2003, fr. (ESA);

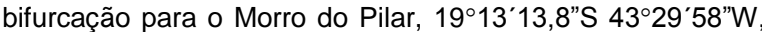
G.O. Romão et al. 865, 28.II.2002, fr. (ESA, SPF); idem, G.O. Romão et al. 884, 10.I.2003, fr. (BHCB, ESA, SP, SPF, UEC); idem, G.O. Romão et al. 1111, 5.XII.2004, fr. (BHCB, ESA, SP, SPF, UEC); Parque Nacional da Serra do Cipó, próximo à estátua do Juquinha, L.S. Kinoshita \& M.E. Mansanares 00/189, 22.XI.2000, fr. (ESA, UEC); idem, G.O. Romão et al. 1112 5.XII.2004, fr. (BHCB, ESA, SPF); RPPN Brumas do Espinhaço, I.R. Andrade et al. 319, 14.V.2012, fl. (BHZB, UEC). Serra do Cipó, estrada para Conceição do Mato Dentro: Km 129-130, A.P. Duarte 2240, 9.XII.1949, st. (RB); Km 134, M. Barreto 1103, 15.IV.1935, fl. (RB); idem, Brade 14891, 15.IV.1935, fl. (RB); Km 137, A.P. Duarte 2171, 7.XII.1949, fl. (RB, UEC); Km 138, A.P. Duarte 2100 e 2102, 6.XII.1949, fl. (ESA, K, RB, UEC); Km 140, A.P. Duarte 8097, 21.VI.1964, fl.fr. (HB, K, MBM, RB, UB); Km 141, M. Barreto 5071, 30.X.1936, fl. (BHCB, R, RB); O. Handro 2278, 6.IX.1976, fl. (SP); C. Sena 649, s.d., fl. (OUPR); Sena\& Schwacke 11785, VIII.1895, st. (RB).

Sleumer (1967) reconheceu duas variedades com base principalmente no tamanho e forma das folhas, sendo elas Gaylussacia reticulata var. reticulata e G. reticulata var. salviifolia. Contudo, Romão (2011 inéd.) sugere a elevação à categoria de espécie da variedade que é restrita à região da Serra da Canastra, razão pela qual é abordada apenas a variedade típica no presente trabalho.

Gaylussacia reticulata distribui-se no domínio cerrado, ao longo da Cadeia do Espinhaço em Minas Gerais e Bahia. Na Serra do Cipó ocorre em campos rupestres, sobre solos pedregosos ou arenosos não alagáveis, comumente próximo de blocos rochosos. Foi coletada com flores ou frutos praticamente ao longo de todo o ano.

Essa espécie é facilmente distinta das demais por apresentar folhas com a nervação reticulódroma, elevado-proeminente na face inferior, margem revoluta a fortemente revoluta e com glândula apical espessoumbilicada. Pelo fato de apresentar tricomas glandulares em indivíduos jovens e geralmente ausentes em indivíduos adultos, é referida duas vezes na chave de identificação. Na Serra do Cipó, é observado que essa espécie juntamente a G. montana e $G$. riedelii são as espécies do gênero mais comumente encontradas. Ilustrações em Meisner (1863), Romão et al. (2004) e Romão (2011 inéd.). 
2.13. Gaylussacia riedelii Meisn. in Mart., Fl. bras. 7: 139, t. 52. 1863.

Fig. 2. E.

Subarbusto a arbusto, $0,2-1(-2) \mathrm{m}$ alt., procumbente. Tricomas simples, alvos, nas folhas, brácteas, às vezes na ráquis; tricomas glandulares ausentes; glândulas clavadas rubras ou nigrescentes, nas folhas e ráquis, capitadas na ráquis, brácteas e flores. Ramos glabros, raramente subglabros, geralmente avermelhados, densamente foliados, ramos velhos desfoliados. Folhas alternas, não imbricadas, $1,2-5,5 \times 0,8-2,5(-3,3) \quad \mathrm{cm}$, rigidamente coriáceas, espessas, discolores, geralmente avermelhadas na face inferior; pecíolo 2-5 mm compr., glabro; limbo oblanceolado, oblongo ou mais comumente obovado a elíptico, raramente suborbicular, ápice agudo a arredondado, geralmente emarginado, mucronulado, com glândula apical espesso-achatada, base aguda a arredondada, margem inteira ou serrilhada próximo do ápice, às vezes glandulosa entre os dentes, plana ou ligeiramente sobrevoluta, ambas as faces glabras, raro esparsamente pubescente na nervura principal da face superior, raramente glandulosas, nervação broquidódroma, nervuras proeminentes, às vezes ligeiramente impressa na face superior. Racemos axilares, geralmente subapicais, 7-27-floro; ráquis 2,6$21,2 \mathrm{~cm}$ compr., angulosa, glabra, às vezes esparsamente pubescente, raramente glandulosa; bráctea foliáceo-coriácea, 3-10 $\mathrm{mm}$ compr., oblanceolada, elíptica ou ovalada, glabra ou pubescente nas bordas, raramente glandulosa nas bordas, com glândula apical espessa; bractéolas 1-4 $\mathrm{mm}$ compr., linear-setiformes ou filiformes, inseridas na porção basal até a apical do pedicelo. Flores laxas ou congestas; pedicelo 3-13(-16) mm compr., glabro ou pubescente e glanduloso; hipanto glabro, raramente glanduloso; cálice 2-4 mm compr., avermelhado, glabro, raramente glandulosa nas bordas, glândula espesso-calosa no ápice dos lobos; corola cilíndrica, tubuloso-campanulada ou campanulada, raramente tubuloso-urceolada, 4-9 mm compr., alva ou rosada, glabra, lobos retos ou recurvados; estames 6-6,5 $\mathrm{mm}$ compr., filete densamente tomentoso, antera granulada; disco nectarífero glabro; estilete ca. $6 \mathrm{~mm}$ compr., glabro. Fruto 3-7(-8) mm diâm., ovóide ou subgloboso, costado, negro a rosado, glabro.

Material examinado: Conceição do Mato Dentro, Serra do Cipó: estrada para Cardeal Mota, $35-40 \mathrm{Km}$ de Conceição do Mato Dentro, R. Tsuji 296, 29.VII.2004, fl.fr. (HPL); estrada do Pilar, Km 143, Mello-Barreto 4411, 12.VIII.1936, fl. (L); Serra das Róseas, A. Macedo 2951, 15.I.1951, fl. (SP). Congonhas do Norte, norte da Serra do Cipó: Serra da Carapina, Serra Talhada: 1852'12"S 4344'14”W, J.R. Pirani et al. 4105, 2.III.1998, fl.fr. (ESA, SPF, UEC); estrada para Conceição do Mato Dentro,

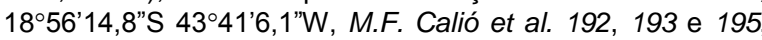
20.I.2007, fl. (SPF); $18^{\circ} 53^{\prime} \mathrm{S} 43^{\circ} 43^{\prime} \mathrm{W}$, A. Rapini et al. 542, 2.III.1998, fl. (SPF). Jaboticatubas, Serra do Cipó, Rodovia Lagoa Santa-Conceição do Mato Dentro-Diamantina: Km
114, CFSC 478, J. Semir \& M. Sazima, 12.XII.1971, fl. (SP); idem, CFSC 2866, A.B. Joly \& J. Semir, 20.VIII.1972, fl. (UEC); idem, CFSC 4795, J. Semir et al., 10.XII.1973, fl. (SP); idem, CFSC 5205, 5209 e 5210, J. Semir et al., 8.IX.1974, fl. (SP, UEC); idem, CFSC 5231, J. Semir et al., 27.XII.1974, fl.fr. (SP, UEC); idem, CFSC 5322, 5323, 5324, 5325, 5326, 5329, 5330 e 5331, J. Semir et al., 10.XII.1974, fl.fr. (SP, UEC); idem, CFSC 5417, L.S. Kinoshita \& J. Semir, 12.XII.1974, fl. (SP); Km 115, CFSC 610a, J. Semir \& M. Sazima, 15.XII.1971, fl.fr. (UEC); idem, CFSC 773, A.B. Joly et al., 4.III.1972, fl.fr.(SP); idem, CFSC 4102, J. Semir et al., 29.IV.1973, fl. (SP); idem, CFSC 5106, J. Semir, 4.IX.1974, fl.fr. (UEC); idem, CFSC 5311, J. Semir et al., 30.X.1974, fr. (SP); idem, A. Flores et al. 588, 4.V.2001, fl.fr. (ESA, UEC); $\mathrm{Km} 121,6 \mathrm{Km}$ a sul do Palácio, $19^{\circ} 18^{\prime} \mathrm{S} 43^{\circ} 35^{\prime} \mathrm{W}$, G. Eiten \& L.T. Eiten 10979, 10.III.1969, fl.fr. (UB); Km 126, Alto do Palácio, F. Barros 1338, 2.Il.1987, fl. (ESA, SP); Km 127, CFSC 497, J. Semir \& M. Sazima, 13.XII.1971, fl.fr. (SP); idem, CFSC 2618, J. Semir \& M. Sazima, 19.VII.1972, fl.fr. (SP, UEC); idem, CFSC 2754, J. Semir et al., 23.VII.1972, fl. (SP); idem, CFSC 5156, 5157, 5158, 5159, 5160, 5161, 5162, 5163 e 5175, J. Semir et al., 7.IX.1974, fl.fr. (SP, UEC); idem, CFSC 5267, 5268 e 5269, J. Semir et al., 29.X.1974, fl.fr. (SP, UEC); idem, CFSC 5420, 5421, 5422, 5423, 5424, $5425,5426,5427,5428,5429$ e 5430, L.S. Kinoshita \& J. Semir, 13.XII.1974, fl.fr. (SP, UEC); idem, CFSC 5442, 5443, 5444, 5445, 5446 e 5447, L.S. Kinoshita et al., 29.IV.1975, fl.fr. (SP, UEC); Km 128, CFSC 299a, A.B. Joly et al., 7.VI.1970, fl.fr. (SP); idem, CFSC 2456, A.B. Joly et al., 29.V.1972, fl. (UEC); idem, CFSC 2954 e 3001, A.B. Joly \& J.

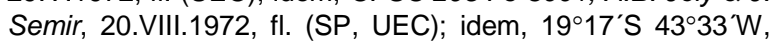
G. Einten \& L.T. Eiten 11047, 11.III.1969, fl.fr. (SP, UB); Km 131, CFSC 1250, A.B. Joly et al., 6.III.1972, fl. (SP); Km 132, CFSC 2019b, J. Semir \& M. Sazima, 30.IV.1972, fl. (SP); idem, CFSC 2373, J. Semir et al., 28.V.1972, fl. (SP); idem, CFSC 3108, A.B. Joly \& J. Semir, 21.VIII.1972, fr. (SP); idem, CFSC 3147, A.B. Joly \& J. Semir, 21.VIII.1972, fl. (SP); idem, CFSC 5145 e 5151, J. Semir et al., 6.IX.1974, fl.fr. (SP); idem, CFSC 5252, J. Semir et al., 28.X.1974, fl.fr. (SP); idem, CFSC 5255, J. Semir et al., 29.X.1974, fr. (SP); idem, CFSC 5336 e 5337, J. Semir et al., 11.XIl.1974, fl.fr. (SP, UEC); idem, CFSC 5434, L.S. Kinoshita \& J. Semir, 14.XII.1974, fr. (SP); idem, CFSC 5439 e 5440, L.S. Kinoshita et al., 29.IV.1975, fl.fr. (SP); Km 133, CFSC 6385, N.L. Menezes et al., 23.VII.1980, fl.fr. (SP); Km 138, CFSC 5431, L.S. Kinoshita \& J. Semir, 14.XII.1974, fl. (SP); Km 142, CFSC 629, J. Semir et al., 6.II.1972, fl.fr. (SP, UEC); 6Km ao norte do Palácio, F. Segadas-Vianna et al. 1091, X.1953, fl. (R); idem, F. Segadas-Vianna et al. 1212, 1953, fl. (R); Fazenda Palácio, G. Hatschbach et al. 28847, 18.I.1972, fl. (MBM); ídem, G. Hatschbach \& Z. Ahumada 31557,14.II.1973, fl.fr. (MBM); G. Hatschbach et al. 28778, 17.I.1972, fl. (MBM). Lagoa Santa, Serra do Cipó, Km 109, A.F. Silva et al. 393 e 452, 1.IV.1983, fl.fr. (VIC). Santa Luzia, Serra do Cipó, M. Barreto 519, 24.VIII.1933, fl. (RB). Santana do Pirapama, norte da Serra do Cipó, distrito de São José da Cachoeira: Fazenda Toucan, trilha João Carrinho, G.O. Romão et al. 2427, 28.XI.2009, fr. (ESA, K, M); trilha para o Cruzeiro, 190'58,7"S 4344'57,7"W, G.O. Romão et al. 1964, 21.II.2007, fl.fr. (ESA, UEC); trilha da Senhorinha, $18^{\circ} 56^{\prime} 31,9^{\prime \prime S} 43^{\circ} 44^{\prime} 59,3^{\prime \prime W}$, G.O. Romão et al. 2358 e 2359, 19.II.2007, fl.fr. (ESA); idem, 18,9422오 $43,7498^{\circ}$ W, V.C. Souza et al. 32865, 19.II.2007, fl. (ESA). Santana do Riacho, Serra do Cipó, Rodovia Belo Horizonte-Conceição do Mato Dentro: Km 107, CFSC 8704, E. Forero et al. 7793, 6.IX.1980, fl.fr. (SP, SPF); idem, caminho para a Usina Dr. Pacífico Mascarenhas, CFSC 8938, E. Forero et al. 8025, 7.IX.1980, fl. (SP); Km 109, CFSC 6163, J.R. Pirani, 6.VI.1980, fl.fr. (SP); idem, C.M. Sakuragui \& V.C. Souza 48, 
2.VIII.1990, fl. (ESA, SPF); Km 112-128, estrada do Hotel Chapéu do Sol, B. Maguire et al. 49063, 7.VIII.1960, fl. (E); $\mathrm{Km}$ 114, N.M. Castro s.n., 8.VI.1989, fl.fr. (BHCB 21197, HUFU 2259); Km 116, G. Martinelli et al. 11372, 26.I.1986, fl.fr. (RB); Km 116,5, G.O. Romão 543 e 545, 2.XI.2000, fl.fr. (BHCB, ESA, SPF); idem, 19॰16'15,3"S 4332'51,5'W, G.O. Romão et al. 897, 916, 917, 918 e 919, 10.I.2003, fr. (BHCB, ESA, RB, SP, SPF, UEC); idem, G.O. Romão et al. 1108, 5.XII.2004, fr. (BHCB, ESA, SPF, UEC); Km 119, Fazenda Cachoeira da Capivara, $19^{\circ} 14^{\prime} 58,1^{\prime \prime} \mathrm{S} 43^{\circ} 32^{\prime} 41^{\prime \prime W}$, G.O. Romão et al. 870 e 872, 28.II.2002, fl.fr. (BHCB, ESA, SPF); idem, V.C. Souza et al. 28621 e 28622, 28.II.2002, fl.fr. (ESA, HPL, SPF, UEC); idem, Fazenda Cachoeira da Capivara, 19॰14'58"S 4332'41"W, G.O. Romão \& A.P.T. Dantas 2263, 8.IX.2007, fl.fr. (ESA); Km 120, H.S. Irwin et al. 20053, 14.II.1968, fl. (NY, UB); Km 125, estrada para o Salitreiro, CFSC 7179, S. Mayo et al., 3.III.1981, fl. (SP, SPF); Km 125,

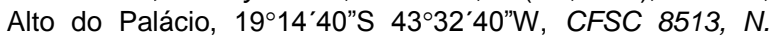
Hensold 410, 7.XII.1981, fl. (MICH, SPF); Km 126, Alto do Palácio, T. Wendt et al. 104, 2.II.1987, fl.fr. (RB); Km 129, CFSC 7534, I. Cordeiro et al., 6.X.1981, fl.fr. (NY, SPF, UEC); Km 130-180, P.Occhioni 5167, 28.VI.1972, fl. (CH); Km 132, M. Sazima 18949, 9.III.1987, fl.fr. (ESA, SPF, UEC); Km 133, CFSC 6385, A.M. Giulietti et al., 23.VII.1980, fl.fr. (SPF, UEC); CFSC 1349, A.B. Joly et al., s.d., fl. (SPF); Km 136, CFSC 5533, A.M. Giulietti et al., 5.VIII.1978, fl. (SP); Km 138, A.P. Duarte 2101, 6.XII.1949, fl.fr. (MBM, RB); Km 140, CFSC 5980, A. Furlan \& M.G. Sajo, 29.Il.1980, fl.fr. (SP); Alto do Palácio, CFSC 12789, R. Simão-Bianchini \& S. Bianchini, 2.VI.1981, fl.fr. (ESA, SPF); cerca de $2 \mathrm{Km}$ após o Córrego Palácio, V.C. Souza et al. 10237, 12.I.1996, fl. (BHCB, ESA, $\mathrm{RB}, \mathrm{SP}, \mathrm{UEC}, \mathrm{US}$ ); cerca de $1-2 \mathrm{Km}$ acima do Córrego Chapéu de Sol, V.C. Souza et al. 11556, 3.VII.1996, fl.fr. (ESA); Fazenda Cachoeira da Capivara, V.C Souza et al. 11608, 4.VIII.1996, fl. (ESA); idem, 19¹4'59,9"S 43.32'44,2"W, V.C. Souza et al. 8227 e 8228, 10.III.1995,

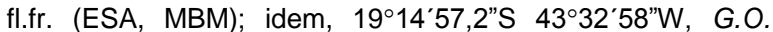
Romão et al. 906, 10.I.2003, fr. (BHCB, ESA, SPF); próximo a bifurcação para o Morro do Pilar, V.C. Souza et al. 10249, 12.I.1996, fl. (BHCB, ESA, MBM, RB, SPF, UEC); idem, 19'13'13"S 43²9'57"W, G.O. Romão et al. 737, 738 e 739, 5.VII.2001, fl.fr. (BHCB, ESA, RB, SP, SPF, UEC); idem, V.C. Souza et al. 25143, 25147 e 25151, 5.VII.2001, fl. (BHCB, ESA, SP, SPF, UEC); idem, G.O. Romão et al. 885,

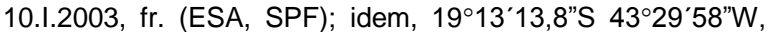
G.O. Romão et al. 861, 28.Il.2002, fl. (BHCB, ESA, SPF); idem, G.O. Romão et al. 1109, 5.XII.2004, fl.fr. (ESA); idem, V.C. Souza et al. 28658, 28.II.2002, fl. (BHCB, ESA, SPF); idem, A.P. Savassi-Coutinho et al. 956, 961 e 962, 11.I.2006, fl.fr. (ESA); próximo à casa do IBAMA, $19^{\circ} 15^{\prime}$ 'S $43^{\circ} 32^{\prime} \mathrm{W}$, L.S. Kinoshita \& J.Y. Costa 00/169, 22.XI.2000, fl. (UEC); entre Porto Palácio e Morro do Pilar, J. Vidal 5972, II.1953, fl. (R); ídem, J. Vidal 6041, VI.1953, fl. (R); entre Porto Palácio e Serro, J. Vidal 1202, XI.1954, fl.fr. (R); estátua do Juquinha, M.A. Farinnaccio et al. 53b, 7.VI.1997, fl. (ESA, HRCB); idem, L.S. Kinoshita et al. 00/175 e 00/187b, 22.XI.2000, fl. (ESA, UEC); idem, I.S.M. Gajardo et al. 48, 4.II.1998, fl.fr. (HRCB, UEC); idem, $19^{\circ} 13^{\prime} 30^{\prime \prime}$ S $43^{\circ} 34^{\prime} 04^{\prime \prime}$, G.O. Romão et al. 732A, 733 e 734, 5.VII.2001, fl.fr. (BHCB, ESA, SP, SPF, UEC);

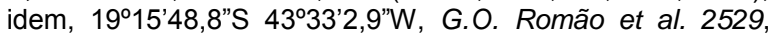
7.IV.2010, fl.fr. (ESA, RB); idem, V.C. Souza et al. 25205, 5.VII.2001, fl. (ESA, SP, UEC); entrada para a Cachoeira da Anta, J.P. Souza et al. 2197, IV.1997, fl.fr. (ESA, SPF); Alto de Congonhas, N.M. Menezes 1260, 10.Il.1991, fl. (SPF); afloramento entre Fazenda Palácio e estátua do Juca, L.S. Kinoshita \& K. Matsumoto 00/572, 22.XI.2000, fl. (UEC); Pico

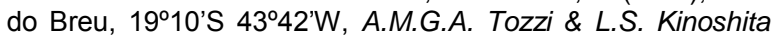
569 e 571, 23.XI.2000, fl. (UEC); RPPN Brumas do Espinhaço, M.G.C. Fernandes et al. 1511, 10.VII.2012, fl.
(UEC); F. Atalo 150, 4.IV.1958, fl. (R); M.M.N. Braga 388, 28.XI.1991, fl. (BHCB); E.P. Heringer \& Castellanos 22222, 6.III.1958, fl.fr. (R); R.E. Nogueira et al. s.n., 6.IV.2001, fl. (OUPR 14160). Parque Nacional da Serra do Cipó: Serra da Bandeirinha, CFSC 10554-B, C. Kameyama et al., 9.IX.1987, fl.fr. (SPF); idem, CFSC12473, A.M. Giulietti et al., 27.VII.1991, fl.fr. (SPF); próximo a sede do IBAMA, CFSC 11915, J.R. Pirani et al., 24.III.1991, fl. (ESA, SPF); idem, CFSC 12278, J.R. Pirani et al., 27.IV.1991, fl.fr. (ESA, SPF); L.D. Meireles et al. 900, 28.II.2002, fl. (UEC). Serra do Cipó, estrada para Conceição do Mato Dentro: $\mathrm{Km}$ 131, A.P. Duarte 2740, 24.IV.1950, st. (RB); Km 135, A.P. Duarte 9691, 23.III.1966, fl. (RB); $\mathrm{Km} 140, A$. Mattos et al. 104, 16.VII.1959, fl. (RB); Serra da Salitreira, I.R. Andrade \& M.B. Horta 57, 12.VII.1987, fl.fr. (BHCB, SPF); Alto de Congonhas, a $12 \mathrm{Km}$ de Cardeal Mota, $19^{\circ} 20^{\prime} \mathrm{S} 43^{\circ} 35^{\prime} \mathrm{W}$, M.M. Arbo et al. 4732, 9.II.1991, fr. (CTES, SPF); Alto do Palácio, estrada para Conceição do Mato Dentro, T.F. Daniel \& N. Hensold 2284, CFCR 3690, 14.II.1982, fl. (SPF); Morro do Breu, ca. de $31 \mathrm{Km}$ do Chapéu de Sol, T.F. Daniel \& N. Hensold 2314, CFCR 3720, 17.II.1982, fl.fr. (SPF); J. Badini \& M. Barreto s.n., 1938, fl. (OUPR 4608); L. Damazio 2028, VI.1908, fr. (RB); J.G. Kuhlmann et al. s.n., 16.I.1951, fl. (RB 72948); E.P. Heringer \& Castellanos s.n., 6.III.1958, fr. (PAMG 6199, SP 79934); E.F. Morato s.n., 13.IX.1986, fl.fr. (VIC 9772 e 9773); M. Pereira \& M. Lucca 878, 22.III.1992, fl. (BHCB, UEC).

Gaylussacia riedelii está restrita à Serra do Cipó e no Planalto Diamantina, porção central da Cadeia do Espinhaço em Minas Gerais. Na Serra do Cipó ocorre em campos rupestres, sobre solos arenopedregosos não alagáveis ou próximo de blocos rochosos. Foi coletada com flores ou frutos ao longo de todo o ano.

Essa espécie é facilmente distinta das demais por apresentar ramos glabros ou subglabros, folhas rigidamente coriáceas, espessas, com a face inferior geralmente avermelhada e lobos do cálice com glândula apical espessa. No aspecto geral da planta, essa espécie assemelha-se bastante a G. ciliosa e $G$. pseudociliosa, discutido anteriormente. Na Serra do Cipó, é observado que $G$. riedelii juntamente a $G$. montana e $G$. reticulata são as espécies do gênero mais comumente encontradas. Ilustrações em Meisner (1863) e Romão (2011 inéd.).

2.14. Gaylussacia rugosa Cham. \& Schltdl., Linnaea 1: 534. 1826.

Fig. 2. J.

Arbusto, 0,5-2 m alt., ereto. Tricomas simples, alvos a ferrugíneos, nos ramos, folhas, flores e frutos; tricomas glandulares fino-alongados, alvos, nos ramos, folhas, flores e frutos, robusto-alongados apenas nas bordas dos lobos do cálice; glândulas clavadas, nigrescentes, nas folhas. Ramos densamente pubescentes a tomentosos e subdensamente híspido-glandulares, esparsamente foliados, ramos velhos desfoliados. Folhas alternas, não imbricadas, 2,4-4,9x1,3-2,3 cm, rigidamente coriáceas, concolores; pecíolo 2-4 mm compr., pubescente a tomentoso e híspido-glandular; limbo elíptico a ovalado, raramente obovado, ápice arredondado, frequentemente emarginado, 
mucronulado, com glândula apical espesso-achatada, base arredondada ou obtusa, margem inteira, ligeiramente revoluta, face superior bulada, pubescente, mais densamente na nervura central, esparsamente híspido-glandular, face inferior tomentosa a velutina, esparsamente híspido-glandular na base da nervura central, glandulosa, nervação eucamptódroma, nervuras impressas na face superior, proeminentes na inferior. Racemos axilares, 6-16floro; ráquis 3-11,1 cm compr., densamente tomentosa e híspido-glandular; bráctea foliácea, 8-11 mm compr., elíptica a rômbica, subdensamente tomentosa e híspido-glandular; bractéolas 5-6 $\mathrm{mm}$ compr., filiformes, inseridas na base do pedicelo. Flores congestas; pedicelo 2-3 $\mathrm{mm}$ compr., tomentoso e híspido-glandular; cálice 4-5 mm compr., densamente tomentoso e híspido-glandular juntamente com o hipanto; corola tubuloso-urceolada a cilíndrica, 8-10 $\mathrm{mm}$ compr., alva, tomentosa, esparsamente vilosoglandular nos ângulos, lobos retos ou ligeiramente recurvados; estames 7-7,5 $\mathrm{mm}$ compr., filete pubescente a tomentoso-glandular, antera lisa; disco nectarífero densamente viloso; estilete 7-9 mm compr., glabro. Fruto 4-6 mm diâm., globoso, ligeiramente costado, negro, tomentoso e híspido-glandular.

Material examinado: Santana do Riacho, Serra do Cipó, Rodovia Belo-Horizonte-Conceição do Mato Dentro, Km 135, B. Stannard et al. CFCR 5991, 14.XI.1984, fl.fr. (ESA, K, NY, SPF).

Material adicional: ESPÍRITO SANTO. Domingos Martins, rodovia Vitória-Belo Horizonte, Km 89, Pedra Azul, G.J. Shepherd 453, 16.VI.1989, fl. (VIES, UEC). MINAS GERAIS. Caeté, Serra da Pedra Redonda, M. Magalhães 2447, 25.XI.1942, fr. (BHCB, HB). Itabirito, W.A. Teixeira s.n., 29.IX.1994, fl. (BHCB 25302b, UEC 74749). Ibitipoca, $H$. Magalhães 1387, VI.1846, fl. (R). Ouro Preto: cachoeira das Andorinhas, J. Badini s.n., 12.X.1974, fl. (OUPR 6003); Camarinhas, J. Badini s.n., 1940, fl. (OUPR 6002); entre cachoeira das Andorinhas e Serra da Brígida, J. Badini s.n. 13.X.1974, fl. (OUPR 6027); Itacolomi, W. Bello 469, 1888, fl. (R); idem, L. Damazio 1238, s.d., fl. (L); Morro de São Sebastião, A.S. Araújo 2100, 1912, fl. (R); idem, L. Damazio s.n., s.d., fl. (OUPR 6001); idem, L. Damazio s.n., 1893, fl.fr. (OUPR 6028); Parque Estadual do Itacolomi, G.O. Romão \& A.P.T. Dantas 2240, 5.IX.2007, st. (ESA); Taquaral, Schwacke 7662, 14.I.1892, fr. (RB). Pico do Itambé,W.R. Anderson et al. 35917, 13.II.1972, fr. (K, MO, NY, RB, UB). Santa Bárbara, Parque Natural da Serra do Caraça, trilha para a Gruta de Lourdes, G.O. Romão \& A.P.T. Dantas 2248, 2249, 2250 e 2251, 6.IX.2007, fl. (BHCB, ESA, RB); Serra do Caraça, J.R. Stehmann s.n., 10.IX.1990, fl. (BHCB 28436, NY 994720). Santo Antônio do Itambé, Pico do Itambé, G.O. Romão et al. 856, 26.II.2002, fr. (ESA); idem, V.C. Souza et al. 28482, 26.II.2002, fr. (ESA, HPL); idem, 18²4'5,9"S 4319'3"W, F. Almeda et al. 9024, 30.XI.2004, fl. (CAS, UEC). Serra do Caraça, cerca de $7 \mathrm{Km}$ a sudeste de Belo Horizonte, em direção ao Carapuça, N.D. Cruz et al. 6433, 18.XI.1977, fl.fr. (ESA, MBM, SP, UEC).

Gaylussacia rugosa distribui-se no domínio cerrado, ao longo da porção centro-sudeste da Cadeia do Espinhaço em Minas Gerais, raramente na Floresta Atlântica no Espírito Santo. Comumente ocorre em beira de matas próximas a campos rupestres, sobre solos arenosos não alagáveis. Com base no material adicional, foi coletada com flores em junho e de setembro a novembro, com frutos em novembro e fevereiro.

Essa espécie caracteriza-se por apresentar ramos e ráquis da inflorescência pubescentes a tomentosos e subdensamente híspido-glandulares, com tricomas glandulares fino-alongados e alvos, de 1-3 mm de comprimento, além de folhas buladas na face superior e ápice frequentemente emarginado. Além disso, relaciona-se com $G$. ciliosa, discutido anteriormente. Ilustrações em Meisner (1863) e Romão (2011 inéd.).

\subsection{Gaylussacia salicifolia Cham. \& Schltdl.,} Linnaea 1: 532. 1826.

Fig. 2. C.

Arbusto ou árvore, 1-2 m alt., ereto. Tricomas simples, alvos, nas folhas e flores; tricomas glandulares ausentes; glândulas clavadas, rubronigrescentes nas folhas, capitado-pediceladas nas flores. Ramos glabros, esparsamente foliados. Folhas alternas, não imbricadas, (3,4-)4,5-8x(0,7-)1-1,8 cm, subcoriáceas a coriáceas, discolores; pecíolo 3-6 mm compr., glabro; limbo estreitamente elíptico ou oblanceolado, raramente oblongo, ápice agudo ou obtuso, mucronulado, com glândula apical espessoalongada, base aguda, margem inteira ou subcrenulada próximo do ápice, plana, ambas as faces glabras, raro esparsamente pubescente na nervura principal da face inferior, glanduloso na face inferior, nervação broquidódroma, nervuras ligeiramente impressas na face superior, proeminentes na inferior. Racemos terminais ou axilares subapicais, 8-12-floro; ráquis 2,9-3,5 cm compr., sempre menor que as folhas, glabra, raramente pubescente, às vezes glandulosa; bráctea 4-8 mm compr., rômbicooblanceolada, glabra, às vezes glandulosa nas bordas; bractéolas 2-3 mm compr., linear-filiformes, inseridas na base do pedicelo. Flores congestas; pedicelo 6-12 $\mathrm{mm}$ compr., glabro, glanduloso no ápice; hipanto raro esparsamente pubescente, frequentemente glanduloso; cálice 1-2 mm compr., glabro, lobos raramente ciliados, ápice desprovido de glândula calosa; corola urceolada, 9-11 mm compr., coccíneovermelha, glabra, lobos retos ou ligeiramente recurvados; estames 7-7,5 mm compr., filete esparsamente pubescente nas bordas, antera granulada; disco nectarífero glabro; estilete $8-9 \mathrm{~mm}$ compr., glabro. Fruto 3-5 mm diâm., ovóide, negro, glabro.

Material examinado: Santana do Riacho, Serra do Cipó, Rodovia Lagoa Santa-Conceição do Mato Dentro, Km 120-121, CFSC 8825, E. Forero et al. 7912, 6.IX.1980, fl. (SP, SPF). Serra de Cipó, Km 132, M. Magalhães s.n., VI.1933, fl. (BHMH 9969, ICN 15982).

Material adicional: GOIÁS. Cavalcante, Chapada dos Veadeiros, G. Hatschbach 36864, 25.V.1975, fl.fr. (MBM). MINAS GERAIS. Barão dos Cocais, Serra do Caraça, trilha da Cascatinha, G.O. Romão et al. 981 e 982, 7.XII.2004, fr. 


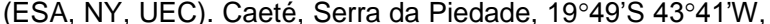
G.L. Esteves et al. CFCR 15442, 16.IX.1990, fl. (SPF). Carrancas: Alto da Serra de Bicas, A.O. Simões et al. 985, 6.XI.1999, fl.fr. (ESA, UEC); Serra do Moleque, A.O. Simões et al. 586, 1.XII.1998, fl.fr. (ESA, UEC). Conceição de Ibitipoca, Parque Estadual do Ibitipoca, perto do Lago dos Espelhos, S.M.S. Verardo et al. 25372, 12.IX.1991, fl. (CESJ, UEC). Diamantina, estrada para Biribiri, a $3 \mathrm{Km}$ do estádio JK, J.R. Pirani et al. CFCR 5568, 15.X.1984, fl. (NY, SP). Itabirito, Serra de Capanema, F.F. Carmo 382 e 418, 10.III.2007, fl. (BHCB). Lavras Novas, Serra do Trovão, G.O. Romão \& A.P.T. Dantas 2232 e 2233, 3.IX.2007, fl.fr. (ESA, K, UEC). Lima Duarte, Parque Estadual do Ibitipoca: Gruta do Monjolinho, 21 ${ }^{\circ} 42^{\prime}$ S $43^{\circ} 53^{\prime} \mathrm{W}$, R.C. Forzza et al. 3931, 18.I.2005, fr. (ESA, RB); trilha para a Gruta do Viajante, M.M. Saavedra et al. 194, 31.VIII.2004, fl. (ESA, RB); trilha para o

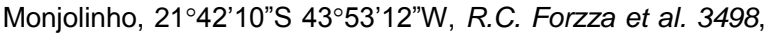
25.VII.2004, fl. (ESA, RB). Ouro Preto, Pico do Itacolomi, L.S. Moura \& M.F. Vieira 410, 15.V.1983, fl. (VIC). Santo Antônio do Itambé, Pico do Itambé, Serra do Gavião, R.W. Windisch \& A. Ghillány 170, 10.IX.1974, fl. (HB). São Thomé das Letras, R. Mello-Silva et al. CFCR 5671, 30.X.1984, fl.fr. (ESA, SPF). Serra do Ibitipoca, P.L. Krieger 9462, 1.XI.1970, fl.fr. (CESJ, ESA, UEC). Serro, estrada para Milho Verde a 13 $\mathrm{Km}$ de Diamantina, L.R. Lima et al. 60, 29.VII.1999, fl. (ESA, SPF). Joaquim Felício, Serra do Cabral: cachoeira da Corrente, F.F. Mazine et al. 832, 20.II.2003, fl. (ESA); idem, G.O. Romão et al. 975, 976 e 977, 20.Il.2003, fl.fr. (BHCB, ESA, SPF); Fazenda da Onça, M.L. Kawasaki et al. CFCR 8175, 1.IX.1985, fl. (ESA, NY, SPF); Morro do Cruzeiro, $R$. Mello-Silva et al. CFCR 8308, 2.IX.1985, fl.fr. (ESA, NY, SPF).

Gaylussacia salicifolia distribui-se no domínio cerrado, ao longo da Cadeia do Espinhaço em Minas Gerais até a Serra do Ibitipoca, raramente no Brasilcentral em Goiás. Na Serra do Cipó ocorre em matas ciliares próximas a campos rupestres, raramente nos campos, sobre solos arenosos geralmente alagáveis. Foi coletada com flores praticamente ao longo de todo o ano, exceto em janeiro e abril, com frutos de setembro a fevereiro e maio.

Essa espécie é caracterizada por apresentar folhas estreitamente elípticas ou oblanceoladas e bastante longas, de (3,4-)4,5-8 cm de comprimento, com a ráquis da inflorescência mais curta que as folhas. Além disso, relaciona-se com G. martii e $G$. oleifolia, discutido anteriormente. Ilustrações em Meisner (1863) e Romão (2011 inéd.).

2.16. Gaylussacia virgata Mart. ex Meisn. in Mart., Fl. bras. 7: 141. 1863.

Fig. 2. $\mathrm{H}$.

Subarbusto, 0,2-0,6 m alt., ereto, virgado. Tricomas simples, alvos, nos ramos; tricomas glandulares fino-alongados amarelados, nos ramos, folhas e flores; glândulas capitado-pediceladas, rubras a amareladas, nas folhas. Ramos esparsa a densamente pubescentes e hispídulo-glandulares, densamente foliados. Folhas alternas a subopostas, imbricadas, 1,1-2,2x0,6-1,3 cm, subcoriáceas a coriáceas, concolores, geralmente verde-amareladas quando jovens; pecíolo 1-2 mm compr., densamente pubescente e tomentoso-glandular; limbo largamente elíptico ou obovado, ápice arredondado a obtuso, mucronulado, com glândula apical espessa, capitada ou achatada, base frequentemente cordada, às vezes arredondada, margem inteira, plana ou ligeiramente revoluta, ciliado-glandular, ambas as faces esparsamente pubescentes, mais densamente na nervura principal, frequentemente tomentosoglandulares, glanduloso na face inferior, nervação broquidódroma, nervuras ligeiramente impressas na face superior, proeminentes na inferior. Racemos axilares subapicais, 6-15-floro; ráquis 1,2-3,3 cm compr., densamente pubescente, esparsamente tomentoso-glandular, glandulosa; bráctea 4-7 mm compr., ovalada a largamente ovalada, densamente pubescente e tomentoso-glandular, glandulosa; bractéolas 3-4 mm compr., elípticas a ovaladas, inseridas na porção mediana até o ápice do pedicelo. Flores congestas; pedicelo $3-5 \mathrm{~mm}$ compr., densamente pubescente e tomentoso-glandular, glanduloso; cálice 2-3 $\mathrm{mm}$ compr., densamente pubescente e esparsamente tomentoso-glandular juntamente com o hipanto, glandulosos; corola tubuloso-urceolada ou subcampanulada, 4-6 $\mathrm{mm}$ compr., alva ou creme, pubescente, glandulosa, lobos retos ou ligeiramente recurvados; estames 3,5-4 mm compr., filete pubescente a tomentoso, antera lisa; disco nectarífero densamente tomentoso; estilete 4-5 $\mathrm{mm}$ compr., esparsamente pubescente. Fruto ca. 4 $\mathrm{mm}$ diâm., globoso, costado, densamente pubescente e tomentoso-glandular.

Material examinado: Santana do Pirapama, Serra do Cipó: Serra Mineira, Fazenda Inhame, $18^{\circ} 55^{\prime} \mathrm{S} 43^{\circ} 54^{\prime} \mathrm{W}$, CFSC 8015, J.R. Pirani et al., 21.III.1982, fl.fr. (ESA, SPF, UEC); idem, $18^{\circ} 57^{\prime}$ 'S $43^{\circ} 46^{\prime} \mathrm{W}$, F.N. Costa \& P. Fiaschi 208, 20.VI.2000, fl.fr. (SPF); idem, $18^{\circ} 55^{\prime} 47,6^{\prime \prime S} 43^{\circ} 47^{\prime} 2,7^{\prime \prime} \mathrm{W}$, G.O. Romão et al. 2383, 27.XI.2009, fl.fr. (BHCB, CESJ, ESA, G, K, L, M, MBM, NY, OUPR, RB, SP, SPF, UEC, VEN, VIC); Serra do Cipó, Fazenda Toucan, 1902'41,94"S 4343'53,83"W, G.O. Romão et al. 2426, 28.XI.2009, fl.fr. (ESA, K); norte da Serra do Cipó, distrito de São José da

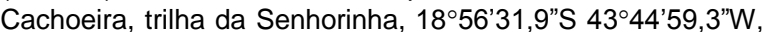
G.O. Romão et al. 2361, 2362, 2363 e 2364, 19.Il.2007, fl.fr. (BHCB, ESA, G, K, L, M, MBM, NY, RB, SP, SPF, UB, UEC); Serra da Lapa, distrito de São José da Cachoeira, trilha da Senhorinha, $18,9422^{\circ} \mathrm{S} 43,7498^{\circ} \mathrm{W}$, V.C. Souza et al. 32737, 32860 e 32861, 19.II.2007, fl.fr. (BHCB, ESA, K, RB, SPF). Santana do Riacho, Serra do Cipó, trilha para o Pico do Breu,

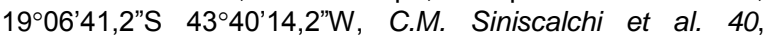
16.VI.2010, fl.fr. (SPF).

Sleumer (1967) reconheceu três variedades com base no indumento dos ramos e folhas, formato, base e margem das folhas, das quais apenas Gaylussacia virgata var. virgata é encontrada na Serra do Cipó. Contudo, Romão (2011 inéd.) sugere a elevação à categoria de espécie de uma variedade e o reconhecimento de um único táxon para as duas outras variedades, razão pela qual elas não são abordadas no presente trabalho.

Gaylussacia virgata distribui-se no domínio cerrado, ao longo da Cadeia do Espinhaço em Minas 
Gerais e Bahia, especialmente na Chapada Diamantina-BA e Planato de Diamantina-MG. Na Serra do Cipó ocorre em campos rupestres situados na porção norte, sobre solos areno-pedregosos não alagáveis, quase sempre entre pedriscos. Foi coletada com flores de novembro a junho, com frutos de novembro a junho.

Essa espécie caracteriza-se por apresentar ramos virgados, base da planta ereta, folhas imbricadas e presença de tricomas glandulares amarelados em toda a planta, especialmente na margem das folhas e inflorescências. As folhas jovens comumente são amareladas em função do denso indumento desta coloração e muitas vezes possuem ligeiro odor de mel, característica compartilhada por outras espécies do gênero com indumento semelhante, como G. pseudogaultheria Cham. \& Schltdl. (Silva \& Cervi 2006). Além disso, relaciona-se com G. centunculifolia, discutido anteriormente. Ilustrações em Romão (2011 inéd.) e Souza \& Lorenzi (2012).

2.17. Gaylussacia vitis-idaea Mart. ex Meisn. in Mart., Fl. bras. 7: 134, t.49. 1863.

Fig. 2. F.

Subarbusto, 0,08-0,3 m alt., ereto. Tricomas simples, alvos, nos ramos, folhas e flores; tricomas glandulares robusto-alongados, rubros, nas brácteas e cálice; glândulas rubras ou nigrescentes, clavadas nos ramos, folhas e cálice, capitadas na ráquis e brácteas. Ramos pubescentes, às vezes glandulosos, esparsamente foliados, ramos velhos desfoliados. Folhas alternas, não imbricadas, (0,9-)1,1-3,6x0,4-1,4 $\mathrm{cm}$, subcoriáceas a coriáceas, discolores, vermelhoacastanhadas na face inferior; pecíolo 1-3 mm compr., glabro ou pubescente; limbo estreitamente elíptico ou obovado a oblanceolado, ápice agudo ou obtuso, raramente arredondado, mucronulado, com glândula apical espesso-capitada, base aguda ou obtusa, margem serrilhada ou crenulada próximo ao ápice, glandulosa entre os dentes, ligeiramente revoluta, face superior não bulada, ambas as faces glabras ou esparsamente pubescentes na nervura principal e próximo das margens, glandulosas, nervação eucamptódroma ou broquidódroma, nervuras proeminentes, às vezes ligeiramente impressas na face superior. Racemos terminais ou axilares subapicais, 3-7-floro; ráquis 0,5-2,4 cm compr., esparsamente pubescente, glandulosa; bráctea 2-4 $\mathrm{mm}$ compr., oblanceolada, ciliado-glandular, bordas glandulosas, desprovida de glândula apical espessa; bractéolas 1-3 mm compr., linear-oblanceoladas a filiformes, inseridas na base até a porção mediana do pedicelo. Flores congestas; pedicelo $2-5 \mathrm{~mm}$ compr., esparsamente pubescente, glanduloso; hipanto glabro ou pubescente; cálice ca. $2 \mathrm{~mm}$ compr., geralmente pubescente e hispídulo-glandular nas bordas, glanduloso; corola urceolada ou tubuloso-urceolada, 5$7 \mathrm{~mm}$ compr., alva ou rosada, glabra, lobos ligeiramente recurvados; estames ca. $4 \mathrm{~mm}$ compr., filete esparsamente pubérulo a pubescente nas bordas, antera lisa; disco nectarífero glabro; estilete ca. 4,5 mm compr., glabro. Fruto 3-4 mm diâm., globoso, costado, vermelho, glabro.

Material examinado: Jaboticatubas, Serra do Cipó, Rodovia Lagoa Santa-Conceição do Mato DentroDiamantina: Km 132, CFSC 267, A.B. Joly et al., 7.VI.1970, fl.fr. (SP, UEC); idem, CFSC 1340, A.B. Joly et al., 6.III.1972, fl.fr. (SP, UEC); idem, CFSC 5144, 5149 e 5150, J. Semir et al., 6.IX.1974, fl.fr. (SP, UEC); idem, CFSC 5438, L.S. Kinoshita et al., 29.IV.1975, fl.fr. (SP, UEC). Santana do Riacho, Serra do Cipó, Rodovia Belo Horizonte-Conceição do Mato Dentro: Km 116,5, G.O. Romão 544, 2.IX.2000, fl.fr. (ESA); idem, 19'16'15,3"S 4332'51,5”W, G.O. Romão et al. 892, 10.I.2003, fl. (ESA); idem, segundo patamar do Alto do Palácio, G.O. Romão et al. 1100 e 1101, 5.XII.2004, fr. (ESA). Serra do Cipó: Velozieto, Nunes et al. s.n., 20.X.1996, fl.fr. (HXBH 12913); km 138, M. Barreto \& Brade 1107, 15.IV.1935, fl. (RB); L. Damazio 2029, VI.1908, fl.fr. (G, L). Local não indicado, Martius s.n., s.d., fl.fr. (L 7229, M).

Gaylussacia vitis-idaea é endêmica da Serra do Cipó, ocorrendo nos campos rupestres, sobre solos arenosos, às vezes com pedriscos, geralmente alagáveis. Foi coletada com flores de setembro a junho, exceto em dezembro, fevereiro e maio, com frutos de setembro a dezembro e de março a junho, exceto em maio.

Essa espécie caracteriza-se por apresentar folhas estreitamente elípticas ou obovadas a oblanceoladas e face inferior comumente glabra, com tricomas glandulares robustos nas bordas dos lobos do cálice. Contudo, assemelha-se aos espécimes CFSC 4702, 5166, 5204, 5265, Romão 732-B e Silvestre 185 os quais foram primeiramente tratados como G. aff. vitis-idaea em Romão (2011 inéd.), mas são tratados no presente trabalho como $G$. pseudociliosa. Diferem quanto ao formato das folhas e indumento da corola, visto que $G$. viti-ideae possui folhas estreitamente elípticas a oblanceoladas e corola glabra, enquanto que $G$. pseudociliosa possui folhas ovaladas, elípticas ou raramente oblongas e corola pubscente nos ângulos. Ilustrações em Meisner (1863) e Romão (2011 inéd.).

\section{Agradecimentos}

Os autores agradecem ao IBAMA pelo apoio logístico durante o trabalho de campo no Parque Nacional da Serra do Cipó, às curadorias dos herbários BHCB, CESJ, GFJP, MBM, OUPR, R, RB, SP, SPF e UEC pela atenção dispensada no envio de materiais e aos ilustradores Wellington Forster e Márcio André Stefanelli Lara.

\section{Referências}

JUDD, W.S. 1984. A taxonomic revision of the American species of Agarista (Ericaceae). J. Arnold Arb. 65: 255-342. 
JUDD, W.S. 1995. Agarista G. Don. In J.L. Luteyn, W.S. Judd, S.E. Clemants, G.M. Diggs, P.D. Sørensen, L.J. Dorr \& G.D. Wallace (eds.), Ericaceae - part II. The superior ovaried genera. Fl. Neotrop. Monogr. 66: 295-344.

JUDD, W.S., CAMPBELL, C.S., KELLOGG, E.A., STEVENS, P.F. \& DONOGHUE, M.J. 2008. Plant Systematics, A phylogenetic approach. Ed. 3. Sinauer Associates. Sunderland.

KINOSHITA-GOUVÊA, L.S. 1980. Estudos taxonômicos e fitogeográficos da família Ericaceae no Brasil. Tese de Doutorado. Instituto de Biociências, Universidade de São Paulo. São Paulo.

KINOSHITA, L.S. 1995. Ericaceae. In B.L. Stannard, Y.B. Harvey \& R.M. Harley (eds.) Flora of the Pico das Almas, Chapada Diamantina-Bahia, Brazil. Royal Botanical Gardens. Kew, p. 291-296.

KINOSHITA, L.S. 1996. Ericaceae. In M.M.R.S. Melo, F. Barros, S.A.C. Chiea, M. Kirizawa, S.L.J. Mendaçolli \& M.G.L. Wanderley (eds.) Flora da Ilha do Cardoso. Instituto de Botânica. São Paulo, vol. 4, p. 15-17.

KINOSHITA, L.S. \& ROMÃO, G.O. 2010. Ericaceae.In R.C. Forzza, J.F.A. Baumgratz, C.E.M. Bicudo, A.A. Carvalho Jr., A. Costa, D.P. Costa, M. Hopkins, P.M. Leitman, L.G. Lohmann, L.C. Maia, G. Martinelli, M. Menezes, M.P. Morim, M.A.N. Coelho, A.L. Peixoto, J.R. Pirani, J. Prado, L.P. Queiroz, V.C. Souza, J.R. Stehmann, L.S. Sylvestre, B.M.T. Walter \& D.C. Zappi (eds.) Catálogo de Plantas e Fungos do Brasil. vol. 2. Andrea Jakobsson Estúdio, Instituto de Pesquisa Jardim Botânico do Rio de Janeiro. Rio de Janeiro. (http://floradobrasil.jbrj.gov.br/2010/FB017330)

KINOSHITA, L.S. \& ROMÃO, G.O. 2011. Ericaceae. In T.B. Cavalcanti \& A.P. Silva (eds.) Flora do Distrito Federal, Brasil. Embrapa Recursos Genéticos e Biotecnologia. Brasília, vol. 9, p.115-127.

KINOSHITA, L.S. \& ROMÃO, G.O. 2012. Ericaceae. In M.G.L. Wanderley, G.J. Shepherd, T.S. Melhem, A.M. Giulietti \& S.E. Martins (eds.) Flora fanerogâmica do estado de São Paulo. Instituto de Botânica. São Paulo, vol. 7, p.151-172.

KINOSHITA, L.S. \& ROMÃO, G.O. 2013. Ericaceae. in Lista de espécies da Flora do Brasil. Jardim Botânico do Rio de Janeiro (http://reflora.jbrj.gov.br/jabot/floradobrasil/FB109).

LUTEYN, J.L., JUDD, W.S., CLEMANTS, S.E., DIGGS, G.M., SØRENSEN, P.D., DORR, L.J., WALLACE, G.D. \& STEVENS, P.F. 1995. Ericaceae - part. II. The superior ovaried genera. Flora Neotropica. vol. 66. The New York Bot. Garden. New York.
LUTEYN, J.L. 2002. Diversity, adaptation and endemism in Neotropical Ericaceae: biogeographical patterns in the Vaccinieae. Bot. Rev. 68(1): 55-87.

MARQUES, M.C.M. 1975. Ericáceas. In P. Reitz (ed.) Flora ilustrada catarinense, parte I, fasc. ERIC. Herbário "Barbosa Rodrigues". Itajaí.

MEISNER, C.F. 1863. Ericaceae. In C.F.P. Martius, A.G. Eichler \& I. Urban (eds.) Flora brasiliensis. Lipsiae. Frid. Fleischer, vol. 7, p. 119-182, tab. 48-57.

MEZABARBA, V., VIANNA FILHO, M.D.M., BORGES, R.A.X. \& MANSANO, V.F. 2013. Ericaceae do Parque Nacional do Itatiaia, RJ, Brasil. Hoehnea 40(1): 115-130.

POHL, I.E. 1831. Plantarum Brasiliae icones et descriptiones hactenus ineditae iussu et auspiciis. Wien, vol. 2. p. 31-42.

ROMÃO, G.O. 2011. Revisão taxonômica de Gaylussacia Kunth (Ericaceae) e estudos da filogenia do gênero. Tese de Doutorado. Instituto de Biologia, Universidade Estadual de Campinas. Campinas.

ROMÃO, G.O. \& SOUZA, V.C. 2003. Flora fanerogâmica do Parque Nacional do Caparaó: Ericaceae. Pabstia 14(1): 1-12.

ROMÃO G.O. \& SOUZA, V.C., 2010. Duas novas espécies de Ericaceae da Cadeia do Espinhaço, Brasil. Rodriguesia 61(supl.): 41-46.

ROMÃO, G.O., WANDERLEY, M.G.L. \& YOKOYA, N. 2004. Flora de Grão-Mogol, Minas Gerais: Ericaceae. Bol. Bot. Univ. São Paulo 22(2): 97-100.

SOUZA, V.C. \& LORENZI, H. 2008. Botânica Sistemática: Guia ilustrado para identificação das famílias de Angiospermas da Flora brasileira, baseado em APG II. Ed. 2. Instituto Plantarum. Nova Odessa.

SOUZA, V.C. \& LORENZI, H. 2012. Botânica Sistemática: Guia ilustrado para identificação das famílias de Fanerógamas nativas e exóticas no Brasil, baseado em APG III. Ed. 3. Instituto Plantarum. Nova Odessa.

SILVA, R.R. \& CERVI, A.C. 2006. As Ericaceae Juss. nativas no estado do Paraná, Brasil. Acta Biol. Paran. 35(1-2): 1-45.

SLEUMER, H. 1959. Studien über die Gattung Leucothöe D. Don. Bot. Jahrb. Syst. 78(4): 435-480.

SLEUMER, H. 1967. Die Gattung Gaylussacia H.B.K. Bot. Jahrb. Syst. 86: 309-384. 